Portland State University

PDXScholar

$1-1-1986$

\title{
Organizational development: an investigation into the knowledge obsolescence of engineers in the electronics industry
}

Cheryl J. Hubbard

Portland State University

Follow this and additional works at: https://pdxscholar.library.pdx.edu/open_access_etds Let us know how access to this document benefits you.

\section{Recommended Citation}

Hubbard, Cheryl J., "Organizational development: an investigation into the knowledge obsolescence of engineers in the electronics industry" (1986). Dissertations and Theses. Paper 825.

https://doi.org/10.15760/etd.825

This Dissertation is brought to you for free and open access. It has been accepted for inclusion in Dissertations and Theses by an authorized administrator of PDXScholar. Please contact us if we can make this document more accessible: pdxscholar@pdx.edu. 
ORGANIZATIONAL DEVELOPMENT: AN INVESTIGATION INTO THE KNOWLEDGE OBSOLESCENCE OF ENGINEERS IN THE

ELECTRONICS INDUSTRY

By

Chery? J. Hubbard

A dissertation submitted in partial fulfillment of the requirement for the degree of

DOCTOR OF EDUCATION

in

PUBLIC SCHOOL ADMINISTRATION AND SUPERVISION

Portlard State University

The University of Oregon

1986 
TO THE OFFICE OF GRADUATE STUDIES AND RESEARCH:

The members of the Committee approve the dissertation of Cheryl J. Rubbard presented May 22, 1986.

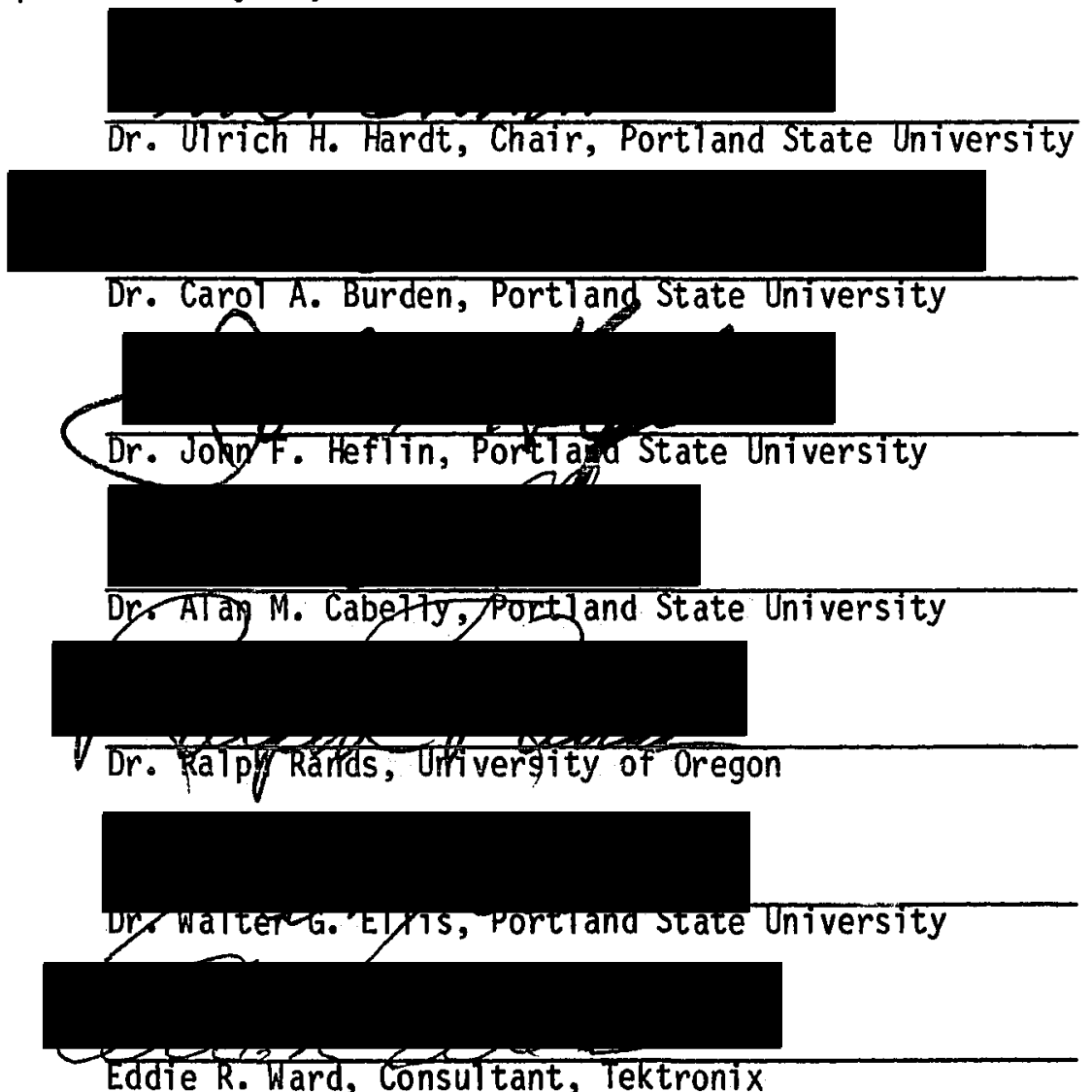

APPROVED:

Robert B. Everhart, Dean, School of Education

Bernard Ross, Acting Dean of Graduate Studies and Research 
AN ABSTRACT OF THE DISSERTATION OF Cheryl J. Hubbard for the Doctor of Education in Public School Administration and Supervision presented May 22, 1986.

Title: Organizational Development: An Investigation into the Knowledge Obsolescence of Engineers in the Electronics Industry.

Dr. Ulrich H. Hardt, Chair, Portland State University

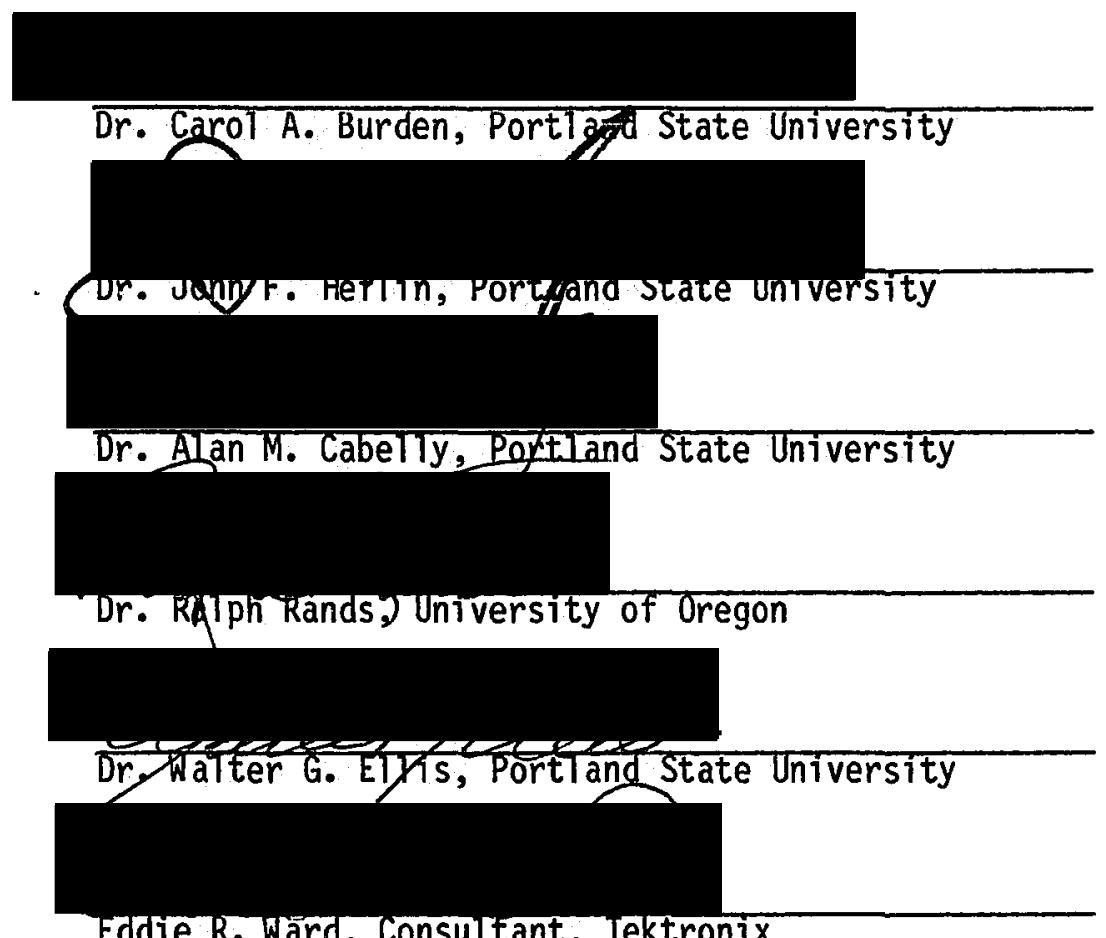

Eddie R. Wărd, Consultant, Tektronix

Purpose

This organizational study was designed to investigate development climate within the context of a single organization 
experiencing rapid change in its environment resulting in increasing employee knowledge obsolescence.

Secondary purposes were: 1) to determine current development methods and the extent of their use; 2) to identify preferred development methods; 3 ) to examine the influence of educational background on development; 4) to examine the influence of length of service on development and 5) to investigate reward preferences and their link to development.

Procedure

The data were collected through a survey of 550 nonmanager engineers. Additional information was obtained from the Human Resource Information System database. The questionnaire consisted of individual background information and a modified version of the Work Description Questionnaire for Engineers (WDQE) with supplemental reward and development sections. Key work environment factors investigated were: 1) organization support; 2) management support; 3) peer support; 4) communication and involvement and 5) work assignments. Responses were obtained from 320 nonmanager engineers. A chi-square analysis tested null hypotheses for education and length of service groups.

\section{Summary of Findings and Conclusions}

The following findings and conclusions resulted from the study:

1) The engineering population differed significantly in their education and length of service backgrounds. 2) Knowledge foundation 
requirements for entry in the organization in the past five years have increased. 3) Non-degree deveiopment is more important for the majority, while degree development is important to bachelor-degreed and shorter length-of-service employees. 4) Reported non-degreed development averaged one course/seminar per year, 2-4 hours of independent reading per week and discussions within the immediate work group. Education groups reported significant differences in internal course/seminar participation and reading behavior. 5) The most effective development methods included a challenging job, reading, an advanced degree, courses/seminars, interdisciplinary teams and internal networking. Education groups showed significant differences for reading and interdisciplinary teams. 6) Primary barriers to development included time, cost, management and workload. 7) The work environment climate for development in the organization was moderate. Peer support received the highest rating; organization, management, and work assignments were rated moderately. Education groups showed greater significant differences than did length of service groups for development climate. 8) The most preferred rewards included salary/merit increases, achievement, advancement, recognition and challenging work. Education groups reported significant differences in key preferred rewards. 9) Moderate opportunity for preferred rewards occurred independent of development behavior. Education groups showed significant differences in opportunity for challenging work with improved development. Length of service groups reported significant differences for opportunity of rewards even with increased development. 


\section{ACKNONLEDGEMENTS}

First, my greatest respect and appreciation is extended to my grandmother, Gladys M. Beckman who has been an endless source of inspiration and encouragement for me throughout my life.

A special appreciation is given to my advisor, Dr. Ulrich $\mathrm{H}$. Hardt, who caringly and masterfully guided me through the doctoral program and to the dissertation committee members, Dr. Carol A. Burden, Dr. John F. Heflin, Dr. Alan Cabelly, Dr. Walter Ellis, Dr. Ralph Rands and Mr. Eddie R. Ward for their expertise, direction, and continuous support.

Finally, this project would still be unfinished without the understanding of my manager, Dr. Angelica Pilato, and the support of my staff, Laura, Tam, Mary and Marilyn. 
TABLE OF CONTENTS

PAGE

ACKNON LEDGEMENTS.................................. i i

LIST OF TABLES................................. vi

LIST OF FIGURES $\ldots \ldots \ldots \ldots \ldots \ldots \ldots \ldots \ldots \ldots \ldots \ldots \ldots \ldots \ldots \ldots \ldots$ viji

CHAPTER

I INTRODUCTION............................... 1

Background........................... 2

Statement of the Research Problem............ 5

Conceptual Framework....................... 5

Assumptions............................ 7

Delimitations of the Study................. 8

Definition of Key Terms................. 8

Importance of the Study.................. 9

Human Resource Management................. g 9

Human Resource Information System.......... 10

Education Theory and Practice............... 10

Electronics Industry................... 12

II REVIEW OF LITERATURE........................ 14

Organization Behavior and Development......... 14

Environment: The Driving Force for

Development........................... 22

An Example: The Technical Organization........ 28

Engineering Development: Research Overview.. 32

Engineering Development: Key Studies....... 35

Conclusion............................. 46

III METHODOLOGY AND PROCEDURES................... 48

Population and Sample...................... 48

Representativeness of Sample............... 50

The Survey Instrument..................... 54

Research Design and Procedures.............. 59

IV DATA PRESENTATION AND DISCUSSION............... 64

Introduction............................. 64

Educational Foundations of Nonmanager Engineers. 66

Non-degreed Engineers.................... 67

Engineers with Bachelor Degrees............ 68

Engineers with Advanced Degrees............. 69

Currentness of Engineering Education......... 69

Currentness of Education by Length of

Service ............................ 70 
Implications for Organization.............. 72

Conclusion............................ 75

Educational Development of Engineers.......... 75

Motivation for Educational Development....... 76

Educational Development Practices........... 78

Degree-Related Development.............. 78

Non-degree Development................. 79

Courses and Seminars................. 79

Independent Reading.................. 82

Networking......................... 83

Effective Development Methods................ 89

Barriers to Development................... 92

Work Environment for Development............. 92

Organizational Support................... 93

Management Support..................... 95

Peer Support.......................... 98

Work Assignments........................ 99

Invol vement/Communication................. 100

Climate................................ 102

Conclusion............................. 104

Rewards.............................. 106

Preferences............................ 106

Relationship to Development............... 109

Analysis of Group Differences................ 112

V. SUMMARY, CONCLUSIONS AND RECOMMENDATIONS........ 115

Introduction........................... 115

Summary ............................... 116

Conclusions............................. 123

Importance of Study....................... 125

Human Resource Management................. 125

Human Resource Information Systems......... 127

Educational Theory and Practice...0.0.000.00. 127

Electronics Industry.................... 132

Recommendations for Further Research......... 133

Bibliography................................... 136

Appendix A...................................... 148

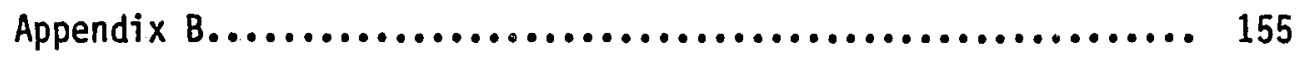

Appendix C......................................... 157 


\section{LIST OF TABLES}

PAGE

TABLE

\begin{tabular}{|c|c|}
\hline II & 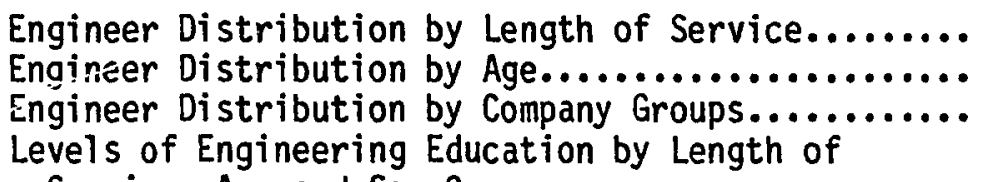 \\
\hline$\underset{V T}{V}$ & $\begin{array}{l}\text { Service, Age and Sex Groups.............................. } \\
\text { Completion Dates of Respondents Engineering Degree. }\end{array}$ \\
\hline VI & $\begin{array}{l}\text { Completion Dates of Engineering Degrees for Length } \\
\text { of Service Groups..................................... } \\
\text { Relationship of Educational Development to Career }\end{array}$ \\
\hline VIII & $\begin{array}{l}\text { for Length of Service Groups...................... } \\
\text { Relationship of Educational Development to Career }\end{array}$ \\
\hline IX & 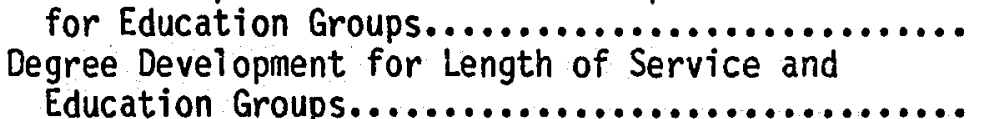 \\
\hline$\underset{y T}{x}$ & Non-degree Course and Seminar Participation......... \\
\hline$X I$ & $\begin{array}{l}\text { Number of Courses/Seminars Taken by Education } \\
\text { Groups } \ldots \ldots \ldots \ldots \ldots \ldots \ldots \ldots \ldots \ldots \ldots \ldots \ldots\end{array}$ \\
\hline XII & Number of Courses/Seminars by Length of Service \\
\hline XIII & 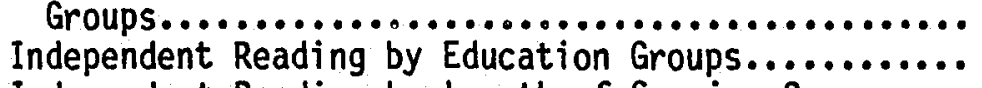 \\
\hline XIV & $\begin{array}{l}\text { Independent Reading by Length of Service Groups.... } \\
\text { Technical Discussion within Work Group for }\end{array}$ \\
\hline XVI & 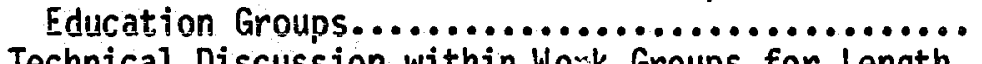 \\
\hline VטTT & 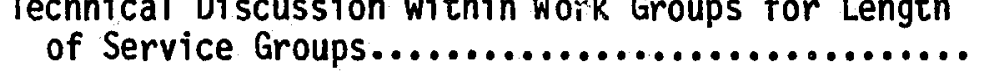 \\
\hline XVII & Networking across Groups/Divisions for Education \\
\hline XVI II & Networking across Groups/Divisions for Length of \\
\hline$X I X$ & $\begin{array}{l}\text { Service Groups...................................... } \\
\text { Networking Outside of Organization for Education }\end{array}$ \\
\hline$X X$ & 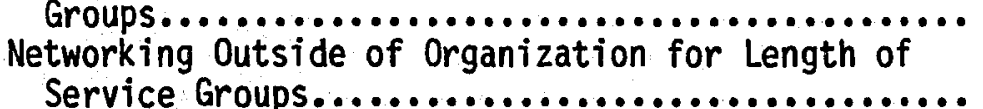 \\
\hline$X X I$ & Summary of Networking Behc \\
\hline XXII & $\begin{array}{l}\text { Non-degree Development Summary } \\
\text { Working on Degrees........... }\end{array}$ \\
\hline XXIII & ree Development Summar \\
\hline
\end{tabular}


XXIV List of Effective Development Methods............. 91

XXV Organization Support for Development.............. 94

XXVI Management Support for Development............... 97

XXVII Peer Support for Development..................... 98

XXVIII Work Assignments............................ 100

$X X I X$ Involvement/Communication..................... 101

$X X X \quad C 1$ imate...................................... 103

XXXI Work Environment Summary....................... 105

XXXII Ranking of Reward Preferences.................... 108

XXXIII Opportunity for Reward/Same Skil1................ 110

XXXIY Opportunity for Reward/Improved Skill............ 111

XXXV Group Differences............................. 112 


\section{LIST OF FIGURES}

PAGE

Figure

1 A Systems Model of Organizational Behavior......... 6

2 Model of Organization as a Transformation Process... 16

3 Components of an Organizational System............ 17

4 Model of Integrative Mechanisms for Organizational

Effectiveness............................. 20

5 Dubin's Model of Technical Updating.............. 55

6 Work Description Questionnaire for Engineers Subscale Reliabilities Estimated by Coefficient a] pha.................................. 57

7 A Systems Model of Organizational Behavior......... 117 


\section{CHAPTER I}

\section{INTRODUCTION}

Modern organizational theory increasingly views organizations as systems characterized by interdependent and interactive elements. Open systems interact with their environments taking energy, materials, information from the external environments, transforming these resources into a flow of products and services for users as well as outcomes that maintain and renew the system (French \& Bel1, 1984; Nadler \& Tushman, 1980). The concept of organization as a system is one of the major underlying principles of organizational development -- a continuous process of renewal to achieve sustained organizational effectiveness and efficiency.

With increasingly rapid changes in the environment, organizations must learn to adapt. Organization development at all levels -individual, group, and organization -- provides opportunity for this required change. Change in technology, knowledge, social values and attitudes, international markets influences people's capability to contribute to organizational goals. Thus, knowledge obsolescence in today's organization presents a formidable organization renewal and development issue. 


\section{Background}

Organizations and people together face the challenge of managing knowledge obsolescence in work settings as technological change, increased world competition and shifting labor force values and expectations exert new pressures on the production of quality goods and services. Knowledge obsolescence threatens both the individual's ability to contribute as well as the organization's ability to adapt to changing environmental conditions. Technological change, economic pressures and increasing complexity of jobs contribute to the accelerating pace of knowledge obsolescence in today's work environments (Westcott, 1976; Best, 1984).

For the individual, not confronting knowledge obsolescence may have serious consequences: reduced ability to perform effectively, displacement, temporary layoff, and even termination. The individual who seeks personal satisfaction and growth through work may experience over time the frustration of eroded performance, diminished contribution and recognition, and a reduced sense of personal competence, achievement and self-worth (Miller, 1977b).

For the organization, not confronting knowledge obsolescence also has critical outcomes: reduced productivity and profitability, increased costs, lowered market position, and even organizational failure. Thus, the organization and the individual together must accept the challenge of eliminating, or at least, diminishing knowledge obsolescence so that they can strive for a mutually beneficial, productive future. 
Knowledge obsolescence has been described in various ways. It has been defined as the lack of knowledge and techniques related to a particular discipline, as reduced individual performance over time, as a discrepancy between job requirements and individual capabilities, and as the erosion of the applicability of knowledge and skills (Criss, 1973; Zelikoff, 1969; Burack, 1972). Essentially, knowledge obsolescence exists when the optimal knowledge and skills necessary to produce organizational results are not available to the organization, or if available, they are unused and unnurtured to the maximum benefit of the individual and the organization. Knowledge obsolescence exists, then, when any one or combination of the following conditions persist in an organization:

1. Deficient knowledge and skills that reduce present productivity and innovation.

2. Underutilization of available knowledge and skills that reduce productivity and innovation.

3. Limited development of new knowledge and skills integrally related to future productivity and innovation.

4. Work environments that minimize stimulation and motivation for new knowledge development and application that in turn reduce both present and future innovation and productivity.

Thus, an organization whose present effectiveness and future survival is dependent on competent, current knowledge for innovation and productivity must address these essential questions.

1. To what degree are the existing knowledge and skills limiting productivity and innovation? 
2. To what degree are the available knowledge and skills currently underutilized?

3. To what degree do the work environment and job experiences of individuals optimize exposure to new developments and, thereby, serve as incentives to development of new knowledge and skills?

4. To what degree are new knowledge and skills being developed to increase the capability of the organization for future organizational strength?

Combatting knowledge obsolescence requires the individual and the organization to recognize the degree of change occurring within the organization and its environment and to strategically plan for the continuous development and optimal utilization of the labor force so that the required vitality of the human resources will match the degree of change. Therefore, in the dynamic organization systematic and continuous development of knowledge and skills is vital for long term organizational excellence and continuity of employment for its members.

Thus, lifelong learning is no longer academic conversation, a "perk" given to increase job satisfaction, an enticement for key talent, or a management luxury to be set aside when budgets are tight. Continued, systematic learning is an individual and organizational necessity--a reality for the employee who wants to remain productive and vital and for the organization that wants continued growth, profitability, and innovation. 
Statement of the Research Problem

This research investigates knowledge obsolescence within the context of a private sector organization influenced by rapidly changing external and internal environmental factors for its survival. The investigation includes the following foci:

1) Knowledge Foundations: the extent and currentness of the basic knowledge base evidenced by a combination of employee educational background and experience.

2) Knowledge Renewal: the extent that the knowledge foundation is continually improved or renewed through directed and nondirected learning activities.

3) Development Climate: the extent that the organization sustains a positive, focused development climate for members through its structures and processes.

\section{Concentual Framework}

The framework for the study of knowledge obsolescence is a systems moder emphasizing the influence of the individual, the task, the informal organization and the formal organization on organizational development. (See Figure 1) 


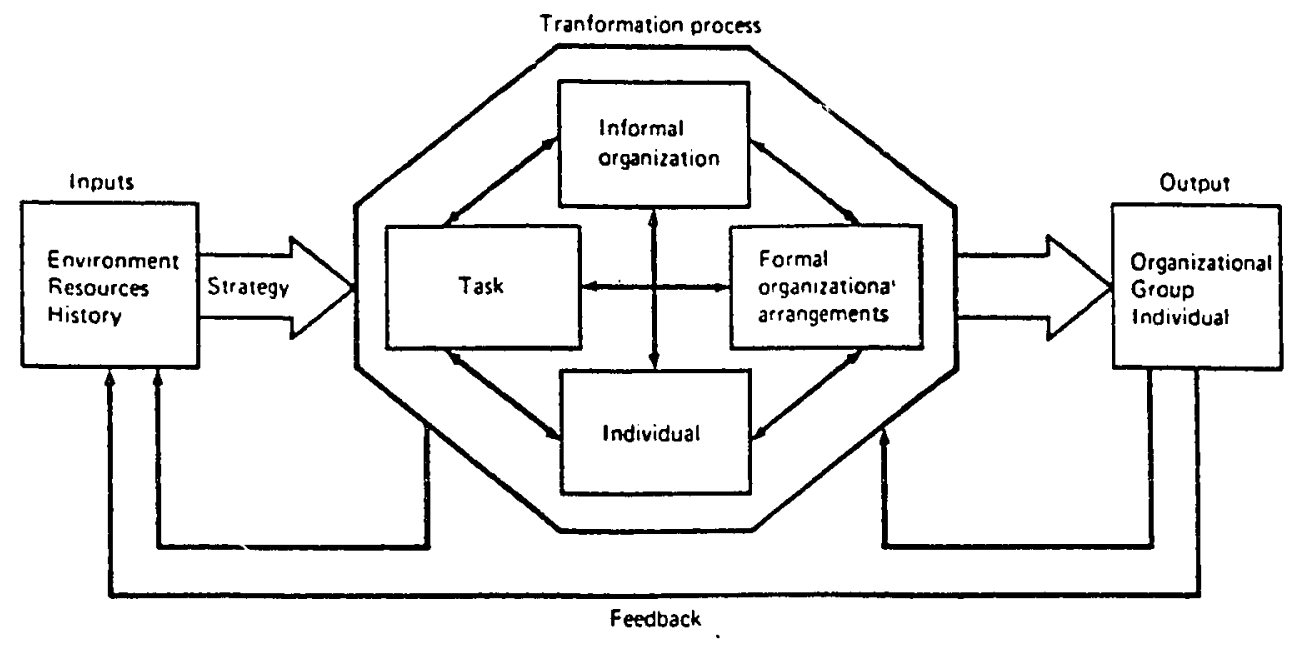

Figure 1. A systems model of organizational behavior (Nadler \& Tushman, 1980).

The study focuses on individual background, behavior, and preferences as well as work environment factors in the informal and formal structure to investigate knowiedge obsolescence. The study is guided by the following central questions:

1. What is the current knowledge base of organizational members?

2. To what degree do members update their knowledge bases?

3. What methods do members prefer to update their knowledge?

4. To what degree do the organization's structure and processes provide focus and support for development?

5. To what degree are the focus and support for development provided independent of members current educational background and experience within the organization? 
Assumptions of the Study

First, this study assumes that people are assets to organizations; therefore, the knowledge foundations, and extent of knowledge renewal, are indicators of the organization's present and future capability. Development climate provides the will, i.e., motivation through management direction and support as well as opportunity to increase the capability of the organization over time.

Secondly, this study assumes that individuals put forth effort for the organization in exchange for available rewards that meet the individual needs and values.

Thirdly, it is assumed that the organization-member relationship is mutually beneficial and one of mutual, if not necessarily equal, influence. Thus, the organization needs to be sensitive to its members' needs, values, work and learning styles. Members must also be sensitive to the demands placed on the organization by the external environment and must be willing to adapt and to develop their capabilities to make continued value-added contributions.

Fourth, this study assumes that a holistic, integrated approach is a viable strategy for the studying of an issue. The systems approach that recognizes the interdependent nature and complexity of organizational systems is recognized as an appropriate way of exploring and defining at the macro level the components and the relationships of an issue. Thus, development as a subsystem of an organization exists within a context and is interdependent for its success or failure with other subsystems in the organization. 
Delimitations of the Study

The study is limited to the nonmanager professional engineering population of a single, medium-sized electronics manufacturing firm in the Northwest.

The study does not attempt to relate development to productivity. To do so would alter the focus of the study, that is, the building of present and future organization capability through continuous development.

\section{Definition of Key Terms}

The following definitions (Lippitt, 1982) are key to understanding of the researcher's perspective on human development within an organizational context:

Holistic: An integrative approach to the examination of development from both the micro and macro aspects of human systems.

Human Sysiems Renewal: A holistic way of investigating micro (individual) and macro (organization and its environment) to further understand their potential for directing energies toward increased ef fectiveness.

Organizational Renewal: A process of initiating, creating and confronting needed changes to ensure the organization's capability to survive over time, i.e., to adapt to new conditions, to solve problems, to learn from experience.

Development: The continuous process of learning (individual, group, organization) from life experiences, interaction with environments and participation in planned development activities. 
Renewal Facilitator: A person or group who initiate change contributing to human systems or organization renewal.

Other definitions specific to this study include:

Electronics Industry: A domain of industry that produces goods and services through innovation, advancement, and application of electronic technology.

Engineer: An individual employed to do engineering work.

Knowledge: Information applied to the innovation and production of goods and services.

Obsolescence: A condition of incremental or total decline in application or use.

Importance of the Study

Human Resource Management

The persistence of knowledge obsolescence implies that human resource managers must increase their awareness of and capability to manage individual development and career stages of employees with the same rigor as is initially given to attracting talented individuals to the organization. This study will contribute to human resource managers' understanding of key elements influencing development within the context of work as opposed to development independent of the "psychological contract" of the individual and the organization. The study seeks to increase management's understanding that planning for human systems renewal is strategic and must be done in concert with and on an ongoing basis with the organizational planning process or mission, objectives, activities, results to be achieved. This approach contrasts with the traditional view of development at the 
operational level focusing only on activities and programs independent of the strategic thrust of the organization.

Human Resource Information System (HRIS)

The study should benefit HRIS managers in understanding the significance of maintaining updated information of the educational background and dirested learning activities of employees. Without this minimal information, it is difficult, if not virtually impossible, for an organization to readily assess even present capability of the organization to achieve its goals, given the current knowledge base of its members. Further, without documenting development behavior, the organization cannot assess the current.iess of the knowledge base on which its future depends.

Education Theory and Practice

The study by investigating an aduit population's learning patterns will provide educators information on the continuing influence of schooling processes on lifelong learning habits. This may, in turn, provide insights as to why development in nonschooling environments continues to $1 \mathrm{ag}$ behind the need for renewal of knowledge and skills, even though opportunities for continued formal schooling have been prevalent. Diebold (1984) indicates that part of the resistance to the change needed for continuous development stems from the educational system that focuses on learnings of the past rather than understanding the present and coping with the future. Thus, educators too need greater awareness that today's knowledge is insufficient and that continuous renewal of knowledge will be imperative for survival in the 
economic environment. It seems essential for educators to acknowledge that imparting of today's knowledge is less important than formerly when an existing knowledge base would essentially be effective for an individual's life. Lewis (1983) suggests that the real critical skills for the 21st century adult include problem solving, analysis, synthesis, critical thinking and communication. Culbertson (1983) too emphasizes that educating youth for information enterprises will require a transition from "muscle power" to "brain power" and development of higher cognitive skills.

Educators need to realize the potential long-term impact of teaching methods and processes on the individual's socialization, interpersonal skills, sense of competence, adaptability, and motivation for continued learning. As this study examines an "at-risk" population in a nonschooling environment experiencing continued change and uncertainty, it will raise questions about the educational processes that contribute to an individual's ability to accept and manage continually changing knowledge bases. Central to this issue are such questions as:

1. To what degree are adults dependent on continued schooling to acquire information needed for their effectiveness?

2. To what degree do adults prefer formal methods of learning versus informal or self-directed systematic learning activities?

3. To what degree do passive learning strategies persist in the adult population and actually serve as barriers to lifelong learning? 
The study of adult learning patterns may assist educational administrators understand the validity of the processes and knowledge/skills taught, practiced, and rewarded in educational institutions.

The criticalness of lifelong learning, the learning to learn concept, as a goal of education has been recognized as essential for life in modern society (Cropley, 1979). Thus, the issue raised by obsolescing knowledge bases is far greater than the content of education. Equally critical are the processes that reinforce individual initiative and strengthen the individual's ability to take charge of life situations, to manage continuous change, to create a "steady-state" when change is rampant and to remain effective even when the environment is uncertain.

\section{Electronics Industry}

Sustained viability in the electronics industry requires a bank of cutting-edge technical and management knowledge and skills. With the rapid shifts in technology, markets, and international competition, organizationai survival is dependent on the talent of its people--human resources--to adapt, to learn, to continuously renew their knowledge/skills in directions related to the organization. Projections in the future of the electronics industry indicate that change will occur at increasingly rapid rates. Further, technical knowledge bases that were valued-added for up to 10 years currently may have a half-life value of 3-5 years. The problem is exaggerated in the industry by reports stating that critical, technical skills of 
the quality required to be competitive will not be available in the market pl ace--essentially a shortage will occur (Hubbard \& Storm, 1984). Thus, electronics companies will become more dependent on present internal talent for future capability. Increasing numbers of competitors for the projected shortage of critical skills further underscores the need for employers in the electronic industry to assess closely their current talent, their present and future knowledge/ski11 needs and to direct employee development to meet the needs of the future. This study should provide electronic industry employers an increased understanding of the issue of knowledge obsolescence that will continue to confront them through the beginnings of the 21st century and exacerbate productivity and the indirect labor costs of the knowledge worker. 
CHAPTER II

REVIEN OF RELATED LITERATURE

Introduction

The foundation of the study of development in organizations begins with a view of modern organizational behavior emphasizing the systems approach to organizational change. With the increasing importance of the externai environment on modern organization for survival, the environment is presented as a key driving force for development. Since the focus of this study is on knowledge development in the context of a rapidiy changing, uncertain environment producing high levels of knowledge obsolescence, a review of research related to knowledge obsolescence is presented followed by an overview of current organizational practices of companies in similar dynamic, unceriain environments.

\section{Organization Behavior and Development}

Current theories of organizational behavior emphasize the diversity and complexity of factors that influence organizational effectiveness. The study of human behavior in organizations has grown rapidly following the influential Hawthorne Studies conducted by Elton Mayo, a Harvard psychologist, in the early 1930 's. While the studies 
investigated the influence of the physical environment on productivity, the studies ultimately demonstrated the influence of group norms on individual behavior and the limited value of money as a reward when strategies are perceived to be a threat to job security and potential negative feedback to group members (Robbins, 1983).

Prior to the Hawthorne Study Frederick Taylor introduced scientific management principles in work organizations to improve productivity. Characteristics of the Taylor methodology were time and motion studies that identified the most efficient way to complete a task and the standard time required for completion. Workers were trained in efficient task completion; jobs were repetitive and simplified. While gains in productivity were observed over the previous random approach to work design, employees complained about meaningless and boring work. Other deleterious effects emerged including increases in tardiness, absenteeism, and turnover (Gibson, Ivanavich \& Donnelly, 1982; Robbins, 1983). From these initial unintended learnings, the focus of job technology embedded in work simplification and concern with workers' physical environments broadened to include more attention to human behavior on job design and organizational effectiveness. A review of current organizational behavior theorists (Robbins, 1983; Gibson et a1., 1982; Ivancevich, Szilagyi \& Wallace, 1977; Hackman, 1983; Nadler, Hackman \& Lawler, 1979) shows an increasing trend to a systems approach to organizational behavior in organizations with a focus of improved human resource utilization for increased productivity, performance and individual satisfaction as a second-level outcome. Present models of organization behavior include the tasks--the 
work to be done--individuals, groups, organizational configurations, and the enyironment of the organization as essential elements of study. These elements, then, are the primary focus of organizational development and change efforts.

Nadler and Tushman (1980), following the systems perspective, present the organization as a transformation process (see Figure 2). The organization with its major subsystems provides the means for transforming energy and information from inputs to outputs. Four key subsystems are identified: a) the task, b) the individual, c) formal organization arrangements and the d) informal organization (see Figure 3). The task element refers to the work that needs to be done for the organization to meet its purpose and objectives. Key considerations for development of the task component are the types of skill and knowledge required, the inherent rewards of the work, the degree of uncertainty, and the performance constraints including cost and time.

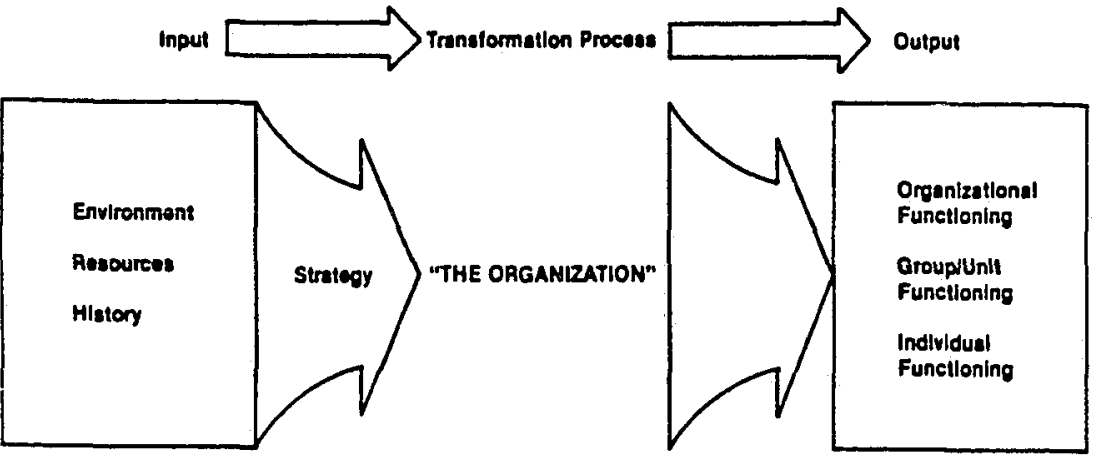

Figure 2. Model of organization as a transformation process TNadler \& Tushman, 1980). 


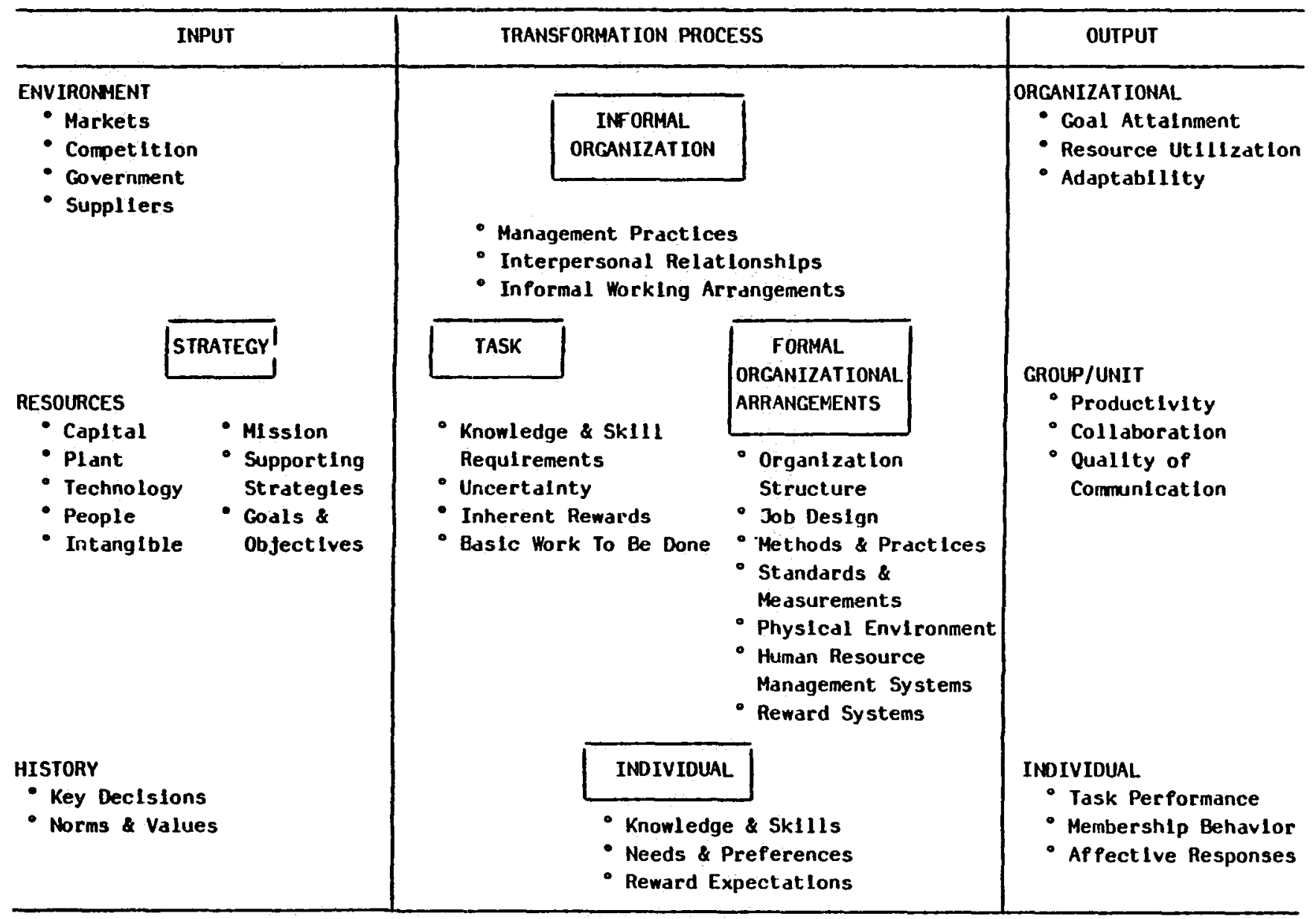

Figure 3. Components of an Organlzational System (Nadler \& Tushman, 1990). 
Individuals, the second subsystem, perform the tasks. Critical elements of individuals influencing performance and, therefore, critical to development are individual knowledge and ski11, needs and preferences, perceptions and experiences, and other background factors.

The formal organization includes a diversity of structures, processes, methods and procedures designed to motivate and optimize individual and group work performance. Examples include job design, reward systems, and human resource systems for sourcing, developing and evaluating people. Finally, the informal system is composed of leader behavior, intergroup and intergroup relations as well as communication and influence processes. These four subsystems as generators of organizational health and effectiveness are the primary focus for continuous development efforts.

Too, the model indicates that the tasks, individual, and groups must be arranged appropriately to meet the demands of the organization's environment. The model asserts that the organization's relation with the environment influences what tasks should be done, what, the appropriate allocation of resources are, and what the best work and organizational design would be given the current environmental conditions and strategy of the organization. The environment in an open social system presents the relationships critical to survival, places constraints on organizational choice, makes demands, and provides opportunities for the organization to use its "unique or distinctive resources and competencies" (Nadler, et a1., 1979). 
For survival the organization must not only develop a strategy, but must have the resources to implement the strategy in a timeframe that meets the competitive market. Thus, resource accounting and allocation is critical. In addition to physical, financial, historical, cultural assets, the individual assets--skills, experience, and commitment--are seen as key determinants of the successful strategy and goal accomplishment. Theorists contend that organizations by their pattern of resource utilization deplete or strengthen and increase resource capacity for the future use of the organization.

A second model of organizational behavior (see Figure 4) depicts the critical nature of the management philosophy in integrating two sets of environmental inputs, those related to market, technology, and regulation and those related to society and culture that influence the people variables over time. Further, the model illustrates the required integration of the organizational variables-goals, tasks, and technology--with the people variables--capabilities, attitudes and needs. The effectiveness of the integrative processes and their congruency with each other ultimately determine the performance of the organization and the satisfaction of the people with their work and with the organization as an emproyer. 


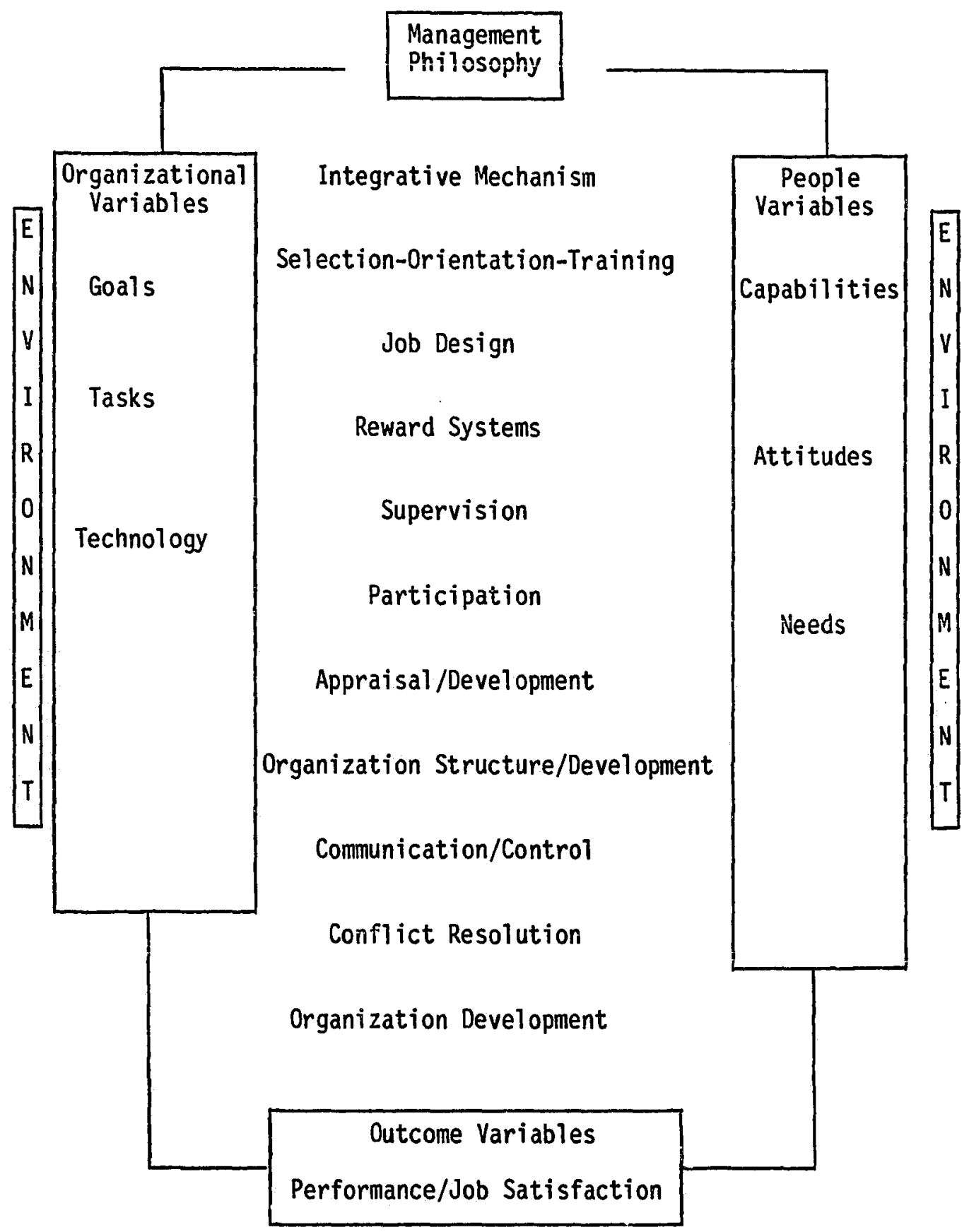

Figure 4. Model of integrative mechanisms for organizational effectiveness (Strauss, Miles, Snow \& Tannenbaum, 1981). 
Both models of organizational behavior establish complexity as the basic element of understanding organizational issues. Further the models reflect the contingency view of behavior and design. The contingency approach, in contrast to normative or prescriptive approaches, is directed at developing actions most appropriate to a given situation. Relevant variables and their relative significance are identified within a given situation; relationships of the variables are considered (Ivancevich, et al., 1977). Thirdly, the models assert the interrelatedness of the elements so that the study of one element necessarily must be studied in view and consideration of all other elements. The totality of consideration given to a variable reflects a holistic and integrative approach to organizational problem solving seen as necessary for decision-making. Thus, current organization behavior models emphasize the examination of relevant variables, not simple solutions (Ivancevich et a1., 1977) for organizational effectiveness.

Organization development plays a key role in the adaptation of an organization to its environment and in the integration of the various internal systems. It has been described in different ways (Margulies \& Raia, 1978): 1) a means of increasing the capacity of the organization to generate and use valid information about itself, 2) a response to change, a complex and educational strategy intended to change the beliefs, attitudes, values, and structure of organizations so they can better adapt to new technologies, markets, and challenges, and change itself, 3) a total system, planned change efforts initiated to cope with organizational issues, 4) a long-range effort 
to improve organizational problem-solving capabilities as a coping response to changes in the external and maternal environment and 5) a value-based process of self assessment and planned change, involving specific strategies and technology, aimed at improving the overall effectiveness of an organizational system.

While organizational development practitioners may differ on definition, scope and methodology (Margulies \& Raia, 1978; French, \& Bell 1984; Lippitt, 1982) one could conclude that organization development has as its purpose the invoking of needed behavior for change within the organization to better achieve the near-term objectives and long-term effectiveness through coping with, adapting to and increasing present and future capacity in relation to the environment. Thus, the environment plays a key role in determining the degree that organizational change efforts are planned, implemented, and continuously integrated into modern organizations.

\section{Environment: The Driving Force for Development}

The organizational environment is a critical component that influences the behavior and success of the organization. An open organizational system has been defined as "a coalition of shifting interest groups that develop goals by negotiation" whose structures, activities and outcomes are strongly influenced by environmental factors (Scott, 1981). This system is dependent on appropriate flows of resources in and out of the organization as well as maintenance of the commitment of their members to contribute resources, energy and time. 
Emery and Trist (1965) after researching a variety of organizations identified four types of environments that require different management responses. The first type, the placid environment, has goals, constraints and opportunities that are unchanged and occur randomly. The appropriate response of the organization is simply to do the best at what it is doing, because no presence or force requires differently.

A second type of environment, though placid, displays clustered configurations of goals, opportunities, and threats that need to be examined in relation to each other. In this environment, Emery and Trist indicate that survival is critically linked with knowledge of the organization's environment. In this environment the objective is optimal positioning in the marketplace and development of distinctive competence.

The third environment, the disturbed-reactive, is characterized by competition. In this environment, adaptability, flexibility, and capability become critical to responding to the persistent, competitive challenge.

Finally, the turbulent, complex environment is dynamic not just in relation to competitors but to changes in the society at 1 arge, i.e., government regulation, public policy, educational institutions, cultural and social values. Also, development and innovation become critical to maintain the capability of the organization to respond effectively to the competitive market. Change is continuous and uncertainty high when compared with the other organizational environments. 
In the operi organizational system, planning and analysis processes identify the internal expectations as well as the external expectations from the organization's environment (Jayaram, 1976). The need for development in an organization is dependent on the degree of change occurring in the organization's environment that forces internal adaptation for continued effectiveness and survival. However, commitment to development as purposeful behavior competes with other organizational goals including production, efficiency, and satisfaction that are near-term considerations for surviva1. Traditionally adaptiveness, flexibility, and development have been viewed as longterm effectiveness strategies that became secondary to near-term goals seen as more integrally related to the present organizational goals and more often rewarded by the organization. This secondary attention to development is, in part, a reflection of high-growth in organizations with stable environments where little necessity for development occurred except as a method to retain and satisfy organizational members.

However, uncertainty and rapid rates of change in today's organizational environments present a different focus and meaning for development (Scott, 1981; Mintzberg, 1979). For example, the greater the degree of uncertainty entering the organization, the greater the need to process information to maintain performance levels (Gailbraith, 1973). Furthermore, to maintain balance with a changing environment, organizations must be able not only to adapt but to innovate when change is outside of their current strategies. Innovation, it is noted, is 1 imited by the quantity and variety of informa- 
tion present in a system. New alternatives for innovative purposes are dependent on 1) the capability of the system to supply information, 2) the range of available information in the system, 3) operating rules affecting analysis and flow of information, and 4) the ability of the system to forget previous solutions (Shafritz \& Whitbeck, 1978). As the environment of the organization increases in. diversity and turbulence, the organization must be able to manage the diversity and change within the organization. Open systems theory stresses the variability of organizational parts, shifts attention from structure to process, and recognizes adaptation to the environment as critical for survival (Scott, 1981).

In an open system two key processes have been identified (Scott, 1981). The morphostasis preserves the current structure or state, while morphogenesis changes the system through growth, learning, and differentiation. In a condition of environmental change, the morphogenesis processes should outweigh the morphostasis ones so that the organization is adapting and innovating to meet the demands of the environment.

If the need for development is related to the degree of change and a highly changing environment is established, the next question then is whether or not the organization analyzes its environment, recognizes the changes that are occurring, and then links the occurring change to a need for development. Further, it is increasingly recognized that the work environment with its many different factors influences not only both the degree and quality of work performance (Mintzberg, 1973, 1979; Hersey \& Blanchard, 1977; Walton, 1980; Davis, 
1977; Hackman \& 01 dham, 1975; Pasmore, 1982), but a] so the degree of development and innovation that occurs (Misshauk, 1970; Miller, 1979; Dubin, 1970, 1977; Tushman \& Moore, 1982; Kaufman, 1974, 1979; Farr Emory, Steiner \& Kozlowski, 1984) in the organization. Thus, any study of development in an organization must examine the characteristics of the work environment that enhance or inhibit development. The diversity of individual values, interests, and abilities that exist within the organization also influence whether development is valued, what strategies are appropriate for development, and what rewards will be viewed as incentives for development (MacGregor, 1978; Glueck, 1982; Farr et a1., 1984). Several accounts have been given about the increasing heterogeneity of the labor force, changing values, and emerging expectations. Walton (1984) and Yankelovich and Lefkowitz (1982) note the influence of rising levels of education, wealth and security, and the decreasing emphasis placed on authority by traditional socializing forces in society, including families and schools, the decline in achievement motivation, and the shifting emphasis from individualism to social commitment on the effectiveness of the work force. Herzberg (1979) indicates that identifying the wants and needs of individuals is exacerbated by the mix of the American population that holds conflicting values. Rosow (1981) indicates that people will bring more complex and varied sets of needs to the workplace.

Concomitant with changing values come different expectations. Walton (1984) indicates that today's people want to be challenged, to experience personal growth, and to have influence in organizations. 
At the same time, many organizations are characterized by simple, narrow, or specialized job roles that limit opportunty for development and broadened experiences. Hierarchies, status differentials, and chains of command are also still evident. The intrinsic worth of work is often neglected by the organization while being increasingly important to people. People desire more attention to emotional and psychological aspects of organizational life, including self esteem, openness and warmth.

Macy (1981) in a nationwide survey of American workers reported that over $70 \%$ of people wanted more control over their work, $60 \%$ wanted more pay and fringe benefits, $80 \%$ were concerned about health and job safety, $36 \%$ indicated they were under-utilized and that their skills were not effectively used, and $33 \%$ indicated they had more education than their jobs required. People reported feeling locked into jobs without alternatives, and, in general, job satisfaction had declined $8 \%$ between 1973 and 1977 . Macy concludes that while significant progress has been made in working conditions of American workers, the human-relations aspect of work has lagged behind changed attitudes, values and expectations of the people.

In conclusion, complex and various environmental changes-technological, market-based, and social--provide the impetus for another look at human resource development in organizational environments. With the various forces, both external and internal, vying for limited time, energy, and resources of the people and the organization, it is unlikely that development, though vital, will be effective untess all systems of an organization support the drive for develop- 
ment. Thus, the following study, investigating the the subsystems of an organization in supporting development, presents a comprehensive approach to addressing the issue of krisisledge obsolescence in a modern, dynamic organization.

\section{An Example: The Technical Organization}

Technically-based organizations are particularly susceptible to knowledge and skill obsolescence as their survival is dependent on innovation and the advancement of new technologies into quality products and services. Management concern for technical vitality emerged in the 1950's and increased in the 1960's. Many organizations subscribed to continuing education and graduate programs for their technical employees to solve the problem of growing knowledge obsolescence (Miller, 1977b). Yet, even in these progressive organizations where the implications of aging knowledge bases were understood and initial remedies enacted, present indicators suggest that knowledge obsolescence persists and even flourishes (Thompson \& Dalton, 1976; Miller, 1977a). The threat of knowledge obsolescence in technical organizations is mounting in the 1980's as world competition and changing markets drive innovation at increasingly rapid rates and continues to place pressure on productivity improvements (Fitch, 1982).

In the past few years company leaders in the electronics industry have reevaluated their approach to development of engineers. Some have updated educational programs targeted to specific technologies; others have broadened engineering development to include 
personal, business and communications. Two report work climate studies. One has created an integrated approach to development as part of the business planning process.

General Electric (Aerospace Electonic Systems Department)

(Zukowski, 1985) found that major obstacles to continuing engineering education included a) inadequate management support, b) no involvement in business planning, c) insufficient funding in budgets, d) unidentified program goals, objectives and direction, e) poor administration of programs, f) low employee motivation. Following an analysis of shifts in future technology and business environment, AESD overcame these obstacles by establishing a required technical renewal program --a 2-year concentrated-on-site program to put in place the knowledge and skills needed to respond to shifts in the environment. Engineers were required to attend or feel the consequences of demotion, reduced pay, or layoff. Follow-up intensive training in specific technologies was provided. A continuing engineering education program was established under the direction of an engineering education advisory council that identifies trends in technology and critiques proposed and existing courses. Council recommendations are subject to management review and approval. Employee response to these new directions has been favorable, with increased course offerings directed to meeting needs and sharply increased participation in continuing education. Honeywel1's approach to engineering development includes a variety of programs: a) ACE, After-Hours Continuing Education, b) Unite, University-Industry Television for Education, c) Microcomputer and Microelectronics Training and Technical Update, as well as divi- 
sional programs (Sackett, 1985). Yet, with a diversity of programs available, the Vice President of Corporate Research, Science and Technology Operations, reports that problems persist stemming from lack of management and the individual engineer's commitment--budgets, release time, job pressures. Further, the Vice President indicated that the company knows little about the real issues of career management, differences in needs and approaches to development of the engineering population. Currently, Honeywell is exploring its development climate for engineers and the issues surrounding knowledge obsolescence and career management.

Though IBM has had a history of employee development and human resource planning (since 1964) to assist in the employment continuity process, it, too, has updated its approach to human resource planning and personnel issues so that human resource issues are identified at the strategic level (Dyer, 1984). Strategic HRP reports the results of the corporation's environmental scans, special studies and policy decisions by major personnel activities, i.e., personnel planning, employment and recruitment, employee development and compensation. These serve as guidelines and checklists for division and corporate personnel involved in business planning. Corporate personnel requests and reviews personnel information from these areas as an essential part of the human resource planning process. Hewlett Packard also reports a new corporate focus on human resource planning and development as a result of division managers' inability to see the overall impact of overstaffing or forecasting of needed skills. Both IBM and H-P (Levering, Moskowitz \& Katz, 1985) maintain extensive 
educational programs for employees and have served as models for the electronics industry (Moye, 1986).

Alcoa Laboratories (Bridenbaugh, 1985) has shifted from an ad hoc approach for education and training of their scientific and engineering community to one they depict as "thorough and aggressive." The mission and philosophy statements reflect the integral nature of development to the laboratories mission. The strategic plan is based on extensive needs analysis, design and formulation delivery strategy.

Lawrence Livermore National Laboratory (Murphy \& Werne, 1985)

al so provides multiple education programs for their engineers: advanced degree programs, technical non-degree related courses recommended and reviewed by a continuing education committee and employee development programs that concentrate on non-technical career development courses.

These examples demonstrate current approaches to engineering development involving four key elements:

1. A renewed focus and commitment to employee development programs

2. A tighter link and greater control of programs for business objectives

3. Increased forecasting and reporting of development needs as an activity of the business planning process

4. An understanding of the link of limited work environments to employee motivation for development. 
Engineering Deyelopment: Research Overview

Initial research studies of knowledge obsolescence established obsolescence indexes and erosion curves to identify the degree of decline in the existing knowledge of engineers and managers (Mali, 1969; Zelikoff, 1969; Seifert, 1964). Others examined the changing patterns of engineers and scientists related to persistence of performance in organizations (Kaufman, 1974; Dalton \& Thompson, 1977; Bailyn, 1980). Another group of studies investigated the degree that personal, work, and organizational characteristics combined to encourage obsolescence (Kaufman, 1973, 1979; Ritti, 1971; Pelz \& Andrews, 1976). While research studies of engineering performance based largely on manager evaluation has correlated age with declining technical skills, recent studies indicate that organizational climate, management practices, performance systems, job assignments, and reward structures interact to create a work environment that influences longterm technical excellence. Further, these studies 1 ink organizational subsystems to individual development and demonstrate the potential influence of them on the engineer, currentness of technical information, and performance.

The studies suggest that organizations concerned with 1ong-term technical performance assess policies and practices that influence the continued growth of the engineer. Further, strategies need to be developed that consistently support, encourage, and reward development and performance on a career basis. The research also indicates that organizations should examine the methods used for development. While 
organizations continue to look to seminars, courses, and advanced degrees as primary methods for development, engineers may prefer to use other approaches and indicate that the structure of courses are not always compatible with needs, learning style and job requirements. Available courses also may lack current information and may have inappropriate focus and depth for different engineering functions.

Recent studies suggest that organizations approach the issue of technical innovation and excellence differently than in the past. In fact, strategic planning for sustained technical performance may need to include a new orientation to work, job design, development, and career. These findings indicate that extended technical vitality may be achieved by creating a career path that simultaneously provides opportunity and integration of learning and application in the work environment that is rewarded by the organization and valued by the individual. Optimal results may oe achieved if the job, development, and career integration process is systematic and begins prior to selection and continues to separation from the organization. Random approaches to selection, job assignment, development, and career limit the potential technical performance achievable on a long term basis. Prior approaches to technical obsolescence focused on the individual engineer's knowledge for present performance only. While the importance of the current knowledge persists, the concern with technical obsolescence is now extended to future job performance. Thus, development must include strategies for both present and future organizational results. 
Approaches to technical performance are also shifting from measurement to process. The process focus recognizes the significance of managing variables that influence knowledge obsolescence and development. Thus, organizational variables that influence technical development must be identified and their influence measured. The interaction of the individual engineer, the manager, and the work environment forms the basis of the most current studies.

The responsibility for technical development, once entirely placed on the individual engineer, is also changing. Studies indicate that the organization and the individual together must determine the level of technical development to be achieved. Engineers must commit their ability, energy, and motivation to a process of continued development, since rigidity and lack of interest in development as related to organizational goals and objectives increase the potential for reduced technical vitality and job performance. Additionally, the organization plays a critical role in providing a work environment conducive to sustained learning that is rewarded and offers a variety of opportunities for development. Without specific and ongoing direction from the organization, the individual cannot determine independently the knowledge base that the organization will need. Non-directed development efforts, though monetarily supported by the organization, may have 1 imited effectiveness.

In conclusion, sustained technical innovation and excellence require an environment that fosters the continuous development and systematic integration of the individual into the organization--its 
goals, objectives, and future direction--through a varied set of work roles and continuous development strategies.

\section{Engineering Development: Key Studies}

Dalton and Thompson (1971) in their initial study of 1500 design engineers in six organizations examined the relationship of age, technical vitality, and performance over a 14-year period. The study found that fewer older engineers (after mid-thirties) received high performance ratings by managers than younger engineers. No group over 40 had average rankings above the 50th percentile. It appeared that continued lower performance ratings related to diminished rewards and more limited job assignments that in turn increased the loss of tech-

nical skills and reduced the opportunity to learn new technologies. A further examination of job assignments, job complexity and age showed that indeed engineers under 40 had job assignments with higher complexity.

Dalton and Thompson concluded that the organizational environment created a negative performance and reward spiral that discouraged development. This negative spiral contributed to the diminishing technical performance of the engineer and, ultimately, the organization.

Additionally, an examination of the engineers' recent educational experience showed a negative correlation to performance rankings. For example, in one company the engineers over 40 who recently had taken courses were the ones who still received lower performance ratings than those who had not taken courses. This may suggest that 1 ate 
referrals for education or technical updating may be ineffective. Timing of technical development appears to be a critical factor in long-term performance. In contrast, an examination of performance ratings of engineers with master's degrees or intensive mid-career graduate work indicated that this strategy extended the engineers' productive technical work approximately ten years.

A follow-up study of 730 engineers examined engineering performance by age groups (Price, Thompson \& Dalton, 1975). The study attempted to identify factors related to sustained high, medium, and low performance of the engineers. The results showed no significant differences in performance based on reported activities to improve technical competence, i.e., college courses, company courses, reading. However, job-related factors including time spent on the job and job complexity highly correlated to top performance. Further, in contrast to the historical assumption that technical obsolescence related to age, 01 der engineers in the study demonstrated high technical performance. Greater differences in performance appeared within age groups than between age groups.

Additional probing of performance rankings of 311 engineers in two organizations across a 9-year period examined performance gains and losses by age groups (Price, et a7., 1975). Performance rankings were examined for shifts among high, middle, and low performance with others in the age groups. The study reported that engineers over 50 tended to remain in the same performance group. Thus, a high performance at the initial rating tended to predict continued high performance; a lower performance rating initially tended to predict a 
continued pattern of low performance. In the 40-50 age group, twothirds of the initial low performers remained 10w; $90 \%$ of the high performers stayed within the high and middle categories. Middle performers showed the greatest variance with a tendency toward high performance.

In the $30-40$ age group (reflecting performance in the $20^{\prime} \mathrm{s}$ ) slightly more than $50 \%$ of the low performers persisted as low performers. About one-third became middle performers; approximately two-thirds of the high performers continued as high performers. Again, middle performers showed the most variance with slightly less than $50 \%$ remaining as middle performers.

The data showed strong performance persisience patterns in both high and low performing groups across all age groups. These patterns suggest that low performers require immediate identification and systematic review since the pattern begins with the young engineer. An initial low performer needs identification and a plan for continuous improvement to avoid a long-term performance problem. Middle performers appear to require consistent attention to development and performance throughout a career since they are nearly as likely to become low as high performers. A pattern of high performance stability suggests that an organization remove barriers and provide continued challenging work and developmental opportunities for motivated and talented individuals.

A final study of 550 professionals including scientists, engineers, professors, and accountants examined career progression of low and high performers (Dalton, Thompson \& Price, 1977). The study con- 
cluded that professionals with sustained high performance had different career patterns than low performers. The career stages that led to long-term high performance included an initial apprentice stage that emphasized challenging technical work accompanied by induction to the organization by a senior mentor. In the second stage of expertise, the high performer gained credibility through strong technical performance supported by a collegial network. Thirdly, the high performer as mentor had increased responsibility for others through broadened work roles related to the area of expertise gained in stage two. Example roles included consultant, idea person, liaison, and manager. The final stage achieved by a limited few in the organization included people who achieved responsibility for over all strategic planning and direction of at least a major segment of the organization.

The researchers concluded that individuals in all stages of development make significant contributions to the organization. In fact, long-term organizational effectiveness may be related to an appropriate distribution of engineering resources in all four stages. Al so, success in each stage appeared related to success in the prior stage. Success as an individual contributor seemed especially critical to long-term contribution and successful movement to the mentor stage. Further, movement to the mentor stage, both in management and nonmanagement roles, was highly correlated to continued high performance. An examination of five research and development organizations showed that $65 \%$ of the mentor function was accomplished by nonmanagers and $30 \%$ of the sponsor role was attributed to the nonmanager as well. 
This study indicated that sustained high performance was demonstrated by those professionals (independent of age) who successfully moved through initiation, individual contributor, and mentor roles. The percentage of above average performance ratings for individual contributors diminished over time.

Pennsylvania State researchers studied the impact of the work environment and individual characteristics on the performance of engineers. From prior research five key variables were identified: organizational climate, job characteristics, supervisor-subordinate relationship, colleague interaction, and management policy. In their initial study (Farr, Dubin, Enscore, Kozlowski \& Cleveland, 1980) engineers and engineering managers identified ten factors that contributed to development. These included a sense of achievement from the job assignment, challenging work, management expectation of excellence, opportunity to be creative and innovative, opportunity to exercise personal initiative in the job, opportunity for advancement based on quality work, recognition for accomplishments and technical success, salary and merit increases based on performance, opportunity for major responsibility for project, and quality relations with peers.

In a later study (Farr, et al., 1984) of 483 engineers and 220 engineering supervisors in seven organizations, these 10 factors and their influence on the development activities of engineers were examined. The study investigated the engineers' perceptions of the work environment, the reward system, the value of different types of development activities, and the relationship between technical 
currentness and valued rewards. The study was replicated one year later with a reduced population of 231 engineers and 110 supervisors. The findings initially reported remained reliable.

The engineers reported taking more technical courses if they believed that becoming current improved their opportunities for promotion and personal initiative on the job. Correlations between the number of technical courses taken and beliefs about sal ary increase, job security, and challenging work assignments were only slightly less significant. Further, engineers reported taking more technical courses if they perceived a negative impact or reduced opportunity for rewards including less opportunity for assignments on the forefront of technology.

The work environment variables also were associated with the value of development methods. The value of taking in-house seminars, reading technical journals, and peer interaction on technical issues and challenging work, for example, were positively correlated to several yariables including supervisor feedback, policy encouraging development, the technological orientation of the organization, engineer participation in decision-making, technical support, and $\mathrm{cli-}$ mate. The work environment factors also correlated to the engineers' beliefs about whether rewards were available for technical currentness. Challenging work assignments positively correlated with performance ratings, technical knowledge, and continuing education. The study also examined the relationship of the engineers' perception of work environment and supervisory evaluations of technical performance with development activities. The findings showed a posi- 
tive correlation to supervisor communication and technical information exchange, participation in continuing education and job performance. On the other hand, work pressure (time) negatively correlated with ratings of organization and planning, responding to change, and involvement in professional activities.

Two individual factors, age and length of service, were examined in relation to rewards and technical development. Both older and longer service engineers reported less desire for advancement, salary increase and job initiative. Additionally, longer service engineers placed a lower value on challenging work as a reward than did engineers with shorter length of service. 01der engineers also associated less reward with remaining technically current.

Another series of studies conducted by Kaufman (1972, 1975, 1978, 1979) investigated the relationship of personal, work, and organizational factors on technical development. In one study of 110 engineers (Kaufman, 1972) ability predicted currentness of knowledge but did not serve as a predictor for sustained job performance. Kaufman questions the use of performance as a measure of technical currency when individual job assignments may not require the application of a high degree of engineering knowledge.

In another study (Kaufman, 1975), individual differences, early work challenge, and participation in continuing education were examined. Early work challenge positively correlated with graduate courses participation while it negatively correlated with in-house course participation during the early years of service. Graduate courses and in-house course participation also differed according to 
cognitive ability. The study concludes that engineers who are superior in knowledge and ability tend to enroll in graduate courses early in their careers, while those more prone to obsolescent skills tend to avoid difficult graduate courses.

In a study of 404 engineers in a single organization, individual, work, and climate variables significantly related to job performance (Kaufman, 1979). Work assignments, policies, and practices were more important to technical performance than individual differences. Kaufman also studied the methods that engineers perceived as likely to contribute to development. The preferred methods ranked as follows: 1) new job in company, 2) self-study, 3) formal courses, 4) job redesign, 5) company change, 6) career counseling, 7) career change.

The preferred methods of development linked to technical effectiveness. The more current engineers identified self-study, formal courses, and job redesign as their preferred methods with self-study as the most consistent choice. The more obsolescent engineer identified career change, a new job, or a company change as the preferred methods.

Finally, the study examined the relationship of the work environment to career strategies. The study concluded that the key to career development was providing engineers with challenging job requiring high degrees of technical knowledge. Utilization and rewarding of current knowledge and skills stimulated the learning of new knowledge and skill through self-study and course work. 
In the study, age failed to correlate to obsolescence! Age, however, did relate to preferred methods for development. Informal methods--self study and participation--correlated more to technical performance than formal methods of development. In general, Kaufman's research indicates that the organization should examine job assignment strategies and organizational climate factors that influence development. Further, the organization in developing learning strategies and activities must recognize that the preferred methods of development may differ depending on the age, educational background, and job experience of the individual engineers.

An MIT study of 1366 engineering graduates (Bailyn, 1980) indicated that technically trained individuals had varied orientations to work at mid-career that require a variety of roles and career opportunities. The survey examined the job history, work attitudes and values of the targeted population for 10-15 years following graduation. The study identified two key technical career patterns: engineering and scientific-professional. The two patterns showed different career values. The engineering group stressed contribution, high earnings, advancement, and leadership. The scientific-professional career group valued accomplishment, challenge, opportunity to advance knowledge, and creative use of knowledge on the job.

Further, the engineering and scientific-professional career patterns were distinguishable by job positions that resulted in four distinct career types. Staff engineers at mid-career reported the lowest degree of success, work involvement, and job satisfaction. In contrast, engineering managers, consultants, and entrepeneurs felt suc- 
cessful and were satisfied with their job. Science managers and professors exhibited the highest work involvement, success and job satisfaction. The difference among the career patterns suggests a greater need for role differentiation, responsibility and recognition beyond management positions.

In conclusion, the M!T study, reflecting a relatively "homogeneous" technical population as far as education and interests early in their careers, suggested that sustained technical performance requires examination of job roles, management styles, and reward systems for their responsiveness to multiple individual, mid-career orientations, and abilities of technical personnel.

A survey (Adam, 1984) of 1100 electrical engineers examined the methods that engineers use to keep current and the role of continuous learning as related to their work. The survey reported that the job assignment was the single most important factor related to maintaining technicaliy currentness. However, differences existed among age groups. Engineers in the 25-34 age group found job assignment less significant for development than the 35-39 years old. While one-third of the engineers 30-34 years old indicated that continuing education was a strong factor in remaining current, only $23 \%$ of the 55-59 group agreed. In general, older respondents stressed self-study and conferences.

The degree that the engineer needed to stay current to perform the job also related to the method used. Those who perceived technical currentness as essential valued technical publications, job assignments, conferences and self-study more than those where technical 
currentness was less important. The survey also reported that engineers who selected leaving the company placed higher value on continuing education.

Younger engineers reported the highest preference for changing companies. Slightly more than $50 \%$ of the $22-29$ group and $40 \%$ of the 30-34 group indicated a desire to change companies. Engineers in companies without payment for continuing education al so preferred leaving the organization. Further, engineers with a preference for leaving the organization had different reasons for taking continuing education than those preferring to stay with a company. Company leavers cited preparation for a job in a new field, intellectual stimulation, preparation for a new job in the same field, or a salary increase; persisters associated continuing education with improved performance in the job, maintenance of current position in company, and understanding of technologies.

The survey also indicated differences between supervisors' and engineers' reasons for continuing education. Supervisors supported continuing education for understanding technology, preparation for increased responsibility, and improvement of job performance. Though supervisors strongly supported continuing education, $85 \%$ indicated that engineers should decide on what courses to take, while $70 \%$ of the engineers preferred managers to recommend appropriate courses.

Like other studies reporting participation levels, this survey showed that even though both managers and engineers recognized the rapid changes in technology, participation remained low. Reasons for nonparticipation included time, course quality and cost. 
The study also investigated the preferred formats of study. Engineers showed preference for both university-and industry-sponsored courses. Self-study received a strong second rating by $25 \%$ of the respondents. Semester/term courses were preferred by 22-34 year 01ds; engineers 30-39 found it difficult to find courses to meet their interests.

While $75 \%$ of the engineers wanted professional development planning, less than one-third had written plans of development. Supervisors favored the written development plan slightiy more than the engineers.

Conclusion

The current research literature on the development of engineers in technical organizations indicates that individual, work, and organizational factors do influence the degree of continuous development that occurs. Further, the age of engineers does not correlate with knowledge obsolescence except to the degree that age indicates time from development. The key organizational factors associated with sustained technical performance include:

1. An organizational climate and culture that recognizes and supports ongoing technical development and performance.

2. Management and supervisory practices that integrate development with job assignment and performance appraisal.

3. Management accountability for continuous development of technical knowledge within the work group. 
4. Reward systems that include both monetary and visible recognition for development and technical performance.

5. Varied challenging job assignments that stimulate continuous learning and application of technical skills.

6. Varied and continuous development activities that recognize individual preferences for learning targeted to selected changing technologies.

7. Broadly based flexible technical career roles recognized and rewarded by the organization.

Finally, long-term sustained technical excellence requires a work environment that expects, supports, and rewards the continuous development and systematic integration of the individual engineer with the current and future technologies of the organization. Strategies for development, rewards, and job assignments must reflect changing individual interests, capabilities, and preferences. 


\section{CHAPTER III}

\section{METHODOLOGY AND PROCEDUREJ}

A major purpose of this study is to describe the current knowledge base of a population highly sensitive to knowledge obsolescence and their current developmental responses to this "at-risk" position. Additionally, the degree of organizational support for development provided in the work environment is investigated to identify patterns of relationships that emerge between different subpopulations, work environment factors, and the kind and degree of development activity.

This chapter describes the population and sampling procedure, provides a description of the questionnaire, and identifies research design and procedures used to conduct the study.

\section{Population and Sample}

The population for this study includes nonmanager professional engineers in a medium-sized electronics manufacturing firm. An engineer is defined as an individual employed to do engineering work. Unlike other studies that have defined engineers as individuals with a bachelor's degree in engineering, the broader definition allows an examination of the characteristics of an actual engineering population in an organization. The job code classification for engineers 
includes a wide range of nonmanager engineering/scientific functions. Key types of engineers in the organization inciude:

1. Software engineer $21 \%$

2. Electronic engineer 15\%

3. Software/hardware $12 \%$

4. Performance assurance $6 \%$

5. Mechanical/electromechnical $6 \%$

6. Technical writer $6 \%$

7. Manfacturing engineer 5\%

8. IC/hybrid $4 \%$

9. Electron device $3 \%$

10. Software evaluation $3 \%$

11. Principal scientist/engineer $2 \%$

A11 other engineering classifications comprise $1 \%$ or less of the total engineering functions. The listed job codes comprised $83 \%$ of the engineering population in January 1985.

Engineer job groupings are also divided into six job grades: Engineer/scientist I, engineer/scientist II, engineer/scientist III, senior engineer/scientist, principal engineer/scientist, and chief engineer/scientist. Typical minimum qualifications for Level I include a bachelor's degree and/or equivalent experience and training. Level II requires a bachelor's degree with 1-2 years experience or a Master's degree. Level III requires a bachelor's degree with 4-6 years experience or a master's degree with 2-3 years experience, or PhD in appropriate academic discipline. Senior, principal and chief 
engineer/scientist grades include degree requirements with increasing amounts of experience. Current distribution of engineers by job grades are:

1. Level I

2. Level II

3. Level III

4. Senior

5. Principal

6. Chief
$12 \%$

$35 \%$

$34 \%$

$15 \%$

$4 \%$

$2 \%$

Engineers are distributed across the various Groups/Divisions of the company. Ninety-four percent of the engineer/scientists work in seven key groups: Group A, 21.5; Group B-19.6; Group C, 18.7; Group D, 11.1: Group E, 7.8; Group F, 7.7; Group G, 7.5. The remaining 6\% are distributed in administration and corporate groups.

\section{Sample}

A simple random sample of 550 engineers was selected using the Human Resource Information System computer base of professional engineer job codes. The sample size exceeded the number required to ensure a .95 confidence level (Krejcie \& Morgan, 1970) from the total population of 2,213 .

\section{Representativeness of Sample}

With a moderate response rate of $58 \%(n=320)$ from the initial random sample of 550 , several tests were completed to investigate the potential bias of the nonrespondents on the study findings. Tests for 
representativeness of sample included age, sex, length of service and distribucion across Groups of the Organization. Results of the tests for sample representativeness follow:

Length of Service

The length of service of respondents ranged from 1 to 34 years with an average of 8 years. Seventy-nine percent of the respondents had 12 or fewer years of service. The highest single LOS category was 1 year with 17\% followed by 2 years at 11\%, 5 years at 8\%, 7 years at $7 \%$. The sample population distribution skewed toward shorter length of service. However, the respondents' distribution is closely representative of the total engineering population in the company.

TABLE I

ENGINEER DISTRIBUTION

BY

LENGTH OF SERVICE

\begin{tabular}{rcc}
\hline LOS & Sample & Total in Organization \\
\hline $0-5$ & $46 \%$ & $45 \%$ \\
$6-10$ & $26 \%$ & $28 \%$ \\
$11+$ & $28 \%$ & $27 \%$ \\
\hline Total & $100 \%$ & $100 \%$ \\
\hline
\end{tabular}

One might conclude that nonrespondents of the survey would be similar in nature as respondents based on the degree of LOS representativeness of the total engineering population. 
Age

A comparison of the respondents' age distribution with the total population is provided in Table II.

TABLE II

ENGINEER DISTRIBUTION BY AGE

\begin{tabular}{ccc}
\hline Age & Sample & Company Population \\
\hline $20-29$ & $28 \%$ & $26 \%$ \\
$30-39$ & $40 \%$ & $44 \%$ \\
$40-49$ & $16 \%$ & $21 \%$ \\
$50+$ & $5 \%$ & $9 \%$ \\
No age given & $11 \%$ & -- \\
\hline Total & $100 \%$ & $100 \%$ \\
\hline
\end{tabular}

If the probability is higher that older engineers may less often choose not to identify their specific age and the $11 \%$ unindentified were distributed in the $40-49$ and 50+ categories, the age distribution of the respondents would reasonably follow the pattern of age distribution in the total company engineering population. With $53 \%$ of the respondents who did not specify their age indicating an LOS of 11+ years and an additional $18 \%$ indicating LOS of 6-10 years, the assumption seems to have merit. 
Group Distribution

Nonmanager engineers are distributed across seven primary Groups of the organization. Sample and population distribution are reported in Table III.

TABLE III

ENGINEER DISTRIBUTION BY

GROUP

\begin{tabular}{cccc}
\hline Group & Sample & Organization & Difference \\
\hline A & 26.6 & 21.5 & +5.1 \\
B & 16.2 & 19.6 & -3.4 \\
C & 17.5 & 18.7 & -1.2 \\
D & 8.4 & 11.1 & -2.7 \\
E & 8.4 & 7.8 & +.06 \\
F & 8.4 & 7.7 & +.07 \\
G & 7.8 & 7.5 & +.03 \\
H (A11 others combined) & 6.7 & 6.1 & +.05 \\
Total & 100 & 100 & \\
\hline
\end{tabular}

The distribution variance by Groups ranged from $3.4 \%$ underrepresentation in Group B to $5.1 \%$ over representation in Group $A$, the two groups with the largest total population of nonmanager engineers in the organization. Four of the Groups showed 1\% or less variance in response rates. With maximum variance of $5 \%$ to total engineering 
population, the Group sample distribution reasonably reflected the actual distribution.

Sex Distribution

The respondents are $89.4 \%$ male and $10.6 \%$ female. These percentages compare equivalently to a $89.6 \%$ and $10.4 \%$ male and female distribution of nonmanager engineers in the total population.

The Survey Instrument

The questionnarie used for collection of the data on the work environment, reward preferences and their relationships to development, and development activity preference was the Work Description Questionnaire for Engineers developed by a team of Pennsylvania State University researchers funded by the National Science Foundation (Farr et al., 1980, 1984). The WDQE questionnaire and supplemental instruments were designed to test the Dubin technical updating model for engineers (see Figure 4). 


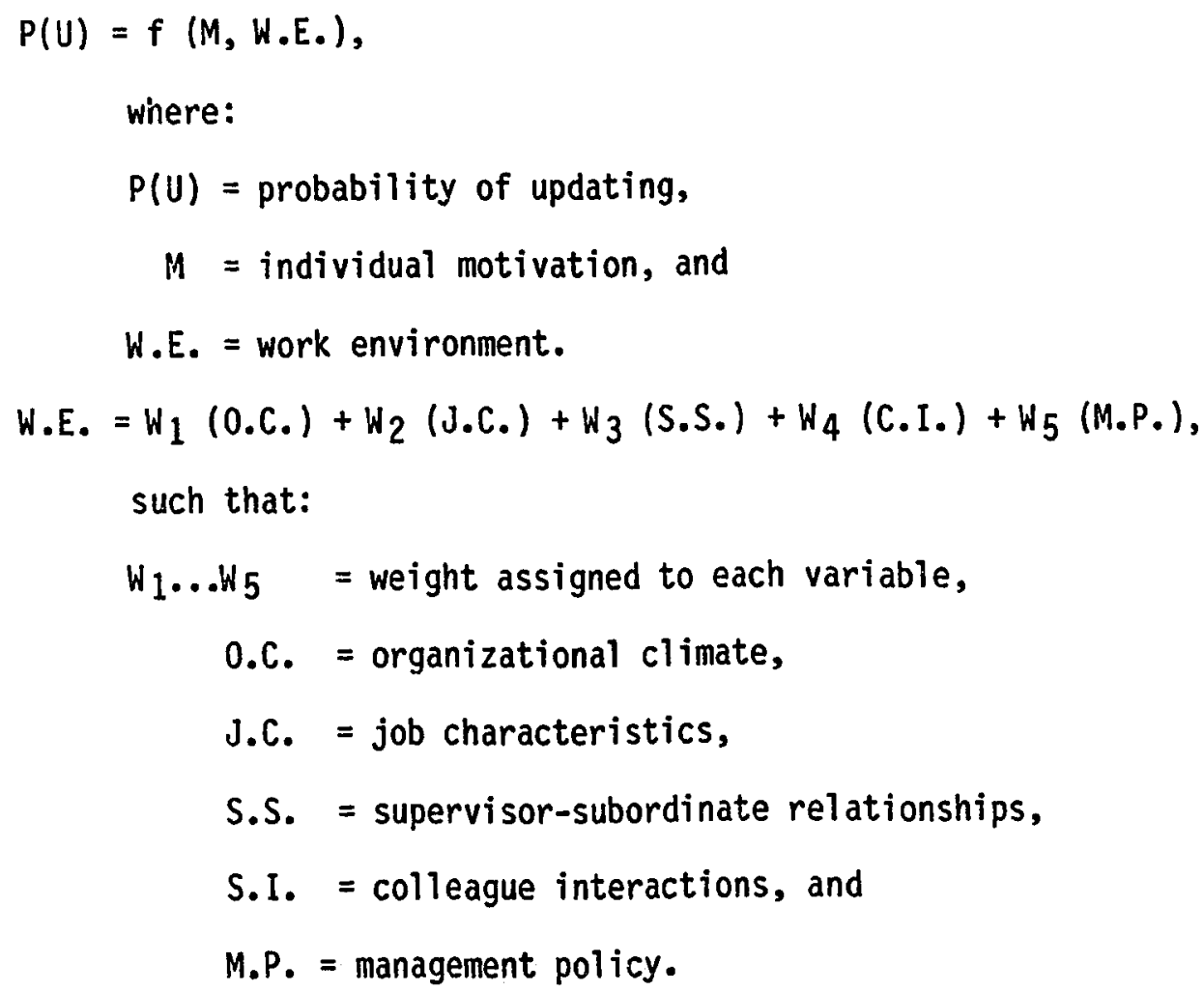

Figure 4. Dubin's model of technical updating (Farr et al., 1980). 
Information for the development of WDQE was obtained from engineers and technical supervisors from 200 private-sector and government organizations. In the interactive design process engineers and engineering managers indicated the degree of influence that each item would have on an engineer remaining technically current. Following the design and testing of the instrument, an initial study was completed with a one-year follow-up study to test the reliability of the instrument.

Since the items of the instrument were developed by a population similar to that of this study, the investigator felt that the WDQE had sufficient content validity to be useful in exploring more in depth the work environment and reward factors of the current population.

From previous research, Dubin (1977) established five key work environment factors that influenced technical-updating -- organizational climate, job characteristics, supervisor-subordinate relationships, colleague interactions, and management policy. The Pennsylvania Studies used the Dubin model as a framework for designing instruments to further trst the relationship of these factors and technical development. The Pennsylvania Studies produced twelve factors (see Figure 5) with varying degrees of reliability that accounted for 54\% of response variance (Farr et al., 1980). All other individual factors produced less than $2 \%$ of the variance. 
Subscale

1. Supervisor Feedback and Communication

2. Organization Policies Encouraging Updating

3. Project and Work Management

4. Technological Orientation of Organization

5. Work Assignments Encouraging Updating

6. Technical Expertise of Peers

7. Engineer's Participation in Organizational Decisions

8. Technical Support within the Organization

9. Organizational Policies Discouraging Updating

10. Comprehensive Project Assignments

11. Availability of Technical Course

12. Assignments to Nontechnical and Repetitive Work

13. Overal] Organizational Attitude
Number of Items

Reliability

10

.84

6

.61

3

.56

7

.80

5

.65

6

.63

11

.81

4

.52

$3 \quad .38$

$4 \quad .48$

1 Not Calculable

$\begin{array}{ll}7 & .66\end{array}$

$27 \quad .95$

Figure 5. Work description questionnaire for engineers subscale reliabilities estimated by coefficient alpha (Farr et al., 1980). 
For this study, only those subscales with .60 or greater reliability were used. Median intercorrelation among the subscales is .35 (Farr et a1., 1980).

Key environment factors included in this study utilize $60 \%$ of the list items of the WDQE; in general, the items are analyzed in the same categories as the WDQE. However, the general areas of the WDQE used in this study have been modified to reflect more clearly the content of the items. The following groupings and definitions were used for examination of environment factors:

1. Company Support--the extent that the company provides clear goals, maintains a competitive market attitude, and provides opportunities for engineers to meet development and performance objectives.

2. Management Support for Development--the extent that managers establish performance goals, solicit ideas, share information, encourage development, and reward appropriate behavior.

3. Peer Support--the extent that peers share ideas, provide feedback, and encourage development.

4. Work Assignments--the extent that job assignments are challenging, interesting, and non-repetitive.

5. Involvement/Communication--the extent that engineers participate in work-related decisions and an open information exchange exists among engineers and managers. 
6. Climate--the extent that the general company "atmosphere" fosters growth, creativity and innovation, and high performance.

The rewards section of the questionnaire seeks to establish what rewards engineers value and to what degree those valued rewards are linked to development. A final section on development activities explores the effectiveness of various development methods.

In addition to work environment, rewards and outcome preferences, and effective development activities, the following types of information were collected to establish population background and recent/current development behavior.

1. Background: primary group within organization, length of service, sex, age, education.

2. Development practices: development plan, degree program, course-seminar participation, independent reading, and networking.

3. Key learning methods.

4. Motivation for learning and importance to current job and career.

5. Key barriers to development within organization.

\section{Research Design and Procedures}

Descriptive research is viewed as appropriate to the exploration of phenomena in a variety of contexts when insufficient knowledge or information is known to generate hypotheses. Purposes of descriptive research include efforts to secure evidence about an existing situa- 
tion or current condition, to identify standards or norms with which to compare present conditions and to make decisions for action friill $\&$ Kerber, 1967). Further, the aim of descriptive research is to conceptualize phenomena and to lay the groundwork for hypothesis testing and prediction (Warwick \& Lininger, 1975). Descriptive research alsosearches for patterns that explain, why, how or when (Murdick, 1969).

It is in the realm of descriptive research that this study is conducted. The study seeks to 1) establish what the current condition of the population is in terms of knowledge foundations and development behavior, perceptions of the work environment, and the relationship of valued rewards to development and then to 2 ) identify patterns within this context of rapid knowledge and organizational change that enhance development or encourage knowledge obsolescence.

A cross-sectional survey served as the primary data collection methodology. Additional information available from the HRIS system was used to validate findings and provide supporting information. The survey provided the base-line data for identifying key subgroups from which to explore patterns of similarity and differences and to measure the significance of those differences on dependent variables.

To increase understanding of knowledge obsolescence in the organization, it seemed reasonable that the basic characteristics and background of the population should first be established to determine the homogeneity or heterogeneity of the population. Then differences in development behavior could be studied in relationship to differ- 
ences in individual backgrounds as further mediated by organizational systems.

Two individual factors of the respondents were used to analyze the similarities and differences of work climate, rewards, and development preferences: length of service, and education. The following null hypotheses were tested:

1. Al1 education and LOS groups will report the same degree of current development behavior. (.05)

2. A11 education and LOS groups will report equivalent work climates. $(.05)$

3. All education and LOS groups will value the same rewards. (.05)

4. A11 education and LOS groups will report the same opportunity for valued rewards if technically current. $(.05)$

5. A11 education and LOS groups will yalue the same developmental activities. (.05)

\section{Pretesting of the Instrument}

A pilot test to further check the validity of the survey instrument for the purposes of the study was conducted. A cross-section of engineers $(N=10)$ by function, culture, sex, educational background, and tenure in the organization were hand selected for the pretest. Each individual was scheduled for a one hour session with the investigator. During the session the researcher explained the focus of the research and the purpose of the pretest. Each individual completed the survey and noted any problems in language and construction of 
items and instructions as they completed the survey. The investigator and the individuai discussed any ambiguities of the questionnaire items as well as possible content omissions related to the intent of the study. In addition, general perceptions of the participants related to the development of engineers were noted. The investigator timed each participant and observed the difficulty of the individual in completing the survey.

As a result of the pretest, changes were made in language, format, and items of the questionnaire to decrease ambiguity, to increase the ease of self-administration, and to personalize the questionnaire for the population. Few content changes were made, i.e., deletions for irrelevance or additions from omission.

In general, pretest participants responded positively to the questionnaire, despite its length and complexity. Participants were eager to discuss their views on development and felt that engineers in the company would respond to the survey. The average time for completion of the survey was 30 minutes.

\section{Survey Procedures}

The survey (Appendix A) was sent to the sample population through the inter-plant mail system at the individual's work site. A cover letter (Appendix B) introduced the investigator, explained the purpose of the survey, and encouraged the engineers to participate. Participants were told that the information provided would be confidential and that a summary of survey results would be made available to them. Individuals were also asked if they would be willing to 
participate in a follow-up interview. A follow-up letter (Appendix C) was sent to ali sampie members. The follow-up letter generated a $10 \%$ increase in response. 


\section{CHAPTER IV}

DATA PRESENTATION AND DISCUSSION

\section{Introduction}

A context of rapid change in technology, increased international and national competition, demographic and social value shifts, demands that American industry increase productivity and the quality of goods and services by substantial margins. An example of this expectation is reflected in one target of the organization under study to decrease product time to market by $50 \%$ in 3 years--an average of $16.67 \%$ a year.

Considering the dynamics of the international marketplace and the competitive state of the electronics industry, these expectations are realistic. These levels of performance must be met to ensure survival of the organization. Yet, for the individuals who must produce these results in the engineering community, both managers and nonmanagers, these expectations may seem impossible especially in view that financial resources are constrained.

To achieve this level of performance change, the human resource contribution must be optimized once the productivity gains from automation, tools and improved material/inventory control systems, i.e., hard technologies are equalized across the industry. It has been 
suggested that improvements in these "hard technolgies" will result in 30 to $50 \%$ improvement in productivity; yet they will be insufficient to be competitive (Snyder, 1984). The soft technologies involving relationships and work design currently provide $80 \%$ of the Japanese advantage. Ultimately, the synergistic use of both hard and soft technologies will provide the competitive edge and the productivity gains required for survival.

People make value-added contributions through two primary means: knowledge/skill and experience. At any point in time the cumulative knowledge/skill of the human resources in an organization is indicative of the present capacity of the organization to achieve its objectives. Focused development behavior is indicative of what the nearterm and, if continuous development is present, the long-term capability of the organization may be. The motivation of the organization and the individuals to direct present knowledge/skill and development behavior to achieve organizational objectives represents the internal environment of will and opportunity (Bl umberg \& Pringle, 1982). The data and discussion of this study are examined in terms of these elements and their implications for the present and future of the organization. Additionally, the present state of knowledge and skill, the differences in individual development behavior, preferences for development activity, and the organization systems that support performance and development are examined.

Information from 320 nonmanager engineers from a random sample of 550 engineer in a mid-size Northwest electronics manufacturing firm has been collected to gain insights inco the characteristics, knowl- 
edge base, and development behavior of an actual engineering population. The engineers also provided information related to their work environment. A modified version of the Work Description Questionnaire for Engineers with a supplemental reward and outcome form developed by a team of Pennsylvania State Researchers (Farr et a1., 1980) was used for this purpose. A narrative of the respondent data describes education and service backgrounds, motivation for educational development, and recent development behavior. Preferences for development incentives and rewards are also analyzed. Information about work environment factors is summarized noting particularly the relationship of rewards to development.

Included in the discussion is an analysis of different subgroups by education and length of service. The key educational subgroups are non-degreed, bachelor-degreed and advanced-degreed engineers. Respondents are also divided into three length of service groups: $0-5$ years, 6-10 years, $11+$ years. The break between the earlier entry years $(0-5)$ and transition years $(6-10)$ to career employees $(11+)$ for engineers in the organization occurs on an average of six years. This is determined by high levels of turnover that the organization experiences in engineers during this time.

\section{Knowledge/Skill Foundations of Nonmanager Engineers}

An essential question of the study investigates the degree that engineers in the company have basic knowledge/skills of engineering. One method of determining the strength of engineering knowledge is 
through educational background in engineering and engineering-related disciplines. The education information has been divided into three categories: non-degree, bachelor's, and advanced degree (master's and doctorate).

Overall, $30 \%$ of the respondents had no engineering-related degree, $50 \%$ reported having earned bachelor degrees, $16 \%$ held master's degrees, and 4\%, doctorates. Primary specializations of the degreed engineers included electrical engineering, computer science, mechanical engineering, mathematics, physical sciences, and other specific engineering disciplines.

\section{Non-degreed Engineers}

Non-degreed engineers exist in all age, length of service and sex groups, but are more prevalent in longer service, older, and male subgroups (Table IV). Eighty-one percent of the non-degreed engineers come from engineers with 6 or more years of experience in the company who are 30 or more years of age. However, $19 \%$ of the non-degreed engineers have 5 or fewer years of experience or are 20-29 years of age. While females represent $11 \%$ of the sample and the total engineering population in the organization, they account for only $6 \%$ of the non-degreed sample.

\section{Engineers with Bachelor Degrees}

Engineers with bachelor degrees show less length of service with more than $50 \%$ reporting $0-5$ years with the company. However, the relationship of bachelor degrees to age is not direct. The highest number of engineers with bachelor degrees is from the 30-39 age group 
with $39 \%$, followed closely by the $20-29$ age group of $37 \%$. Thus, the increased preference for bachelor degrees present in less length of service engineers appears more strongly associated with hiring practices than age. Males are slightly underrepresented (2\%) in the bachelor degree category, while their female colleagues are slightly overrepresented (2\%) in the population.

TABLE IV

ENGINEER EDUCATION BY LENGTH OF SERVICE, AGE AND SEX GROUPS

\begin{tabular}{|c|c|c|c|}
\hline Categories & $\begin{array}{l}\text { No Degree } \\
\% \quad(n)\end{array}$ & $\begin{array}{l}\text { Bachelor's } \\
\% \quad(n)\end{array}$ & $\begin{array}{l}\text { Advanced } \\
\% \quad(n)\end{array}$ \\
\hline \multicolumn{4}{|l|}{ LOS: } \\
\hline $\begin{array}{l}0-5 \\
6-10 \\
11+\end{array}$ & $\begin{array}{ll}19 \% & (18) \\
31 \% & (30) \\
50 \% & (48)\end{array}$ & $\begin{array}{ll}54 \% & (86) \\
26 \% & (42) \\
20 \% & (31)\end{array}$ & $\begin{array}{ll}65 \% & (41) \\
17.5 \% & (11) \\
17.5 \% & (11)\end{array}$ \\
\hline Total & $100 \%(96)$ & $100 \%(159)$ & $100 \%$ \\
\hline
\end{tabular}

AGE:

$\begin{array}{lrrrr}20-29 & 19 \%(18) & 37 \%(58) & 19 \% & (12) \\ 30-39 & 36 \%(35) & 39 \%(62) & 44 \% & (28) \\ 40+ & 31 \%(30) & 13 \%(21) & 27 \% & (17) \\ \text { No Age Given } & 14 \%(13) & 11 \%(18) & 10 \% & (06) \\ \text { Total } & 100 \%(96) & 100 \%(159) & 100 \% & (63)\end{array}$

SEX:

\begin{tabular}{lllll} 
Male & $94 \%(90)$ & $87 \%(138)$ & $89 \%$ & $(56)$ \\
Female & $06 \%(06)$ & $13 \%(21)$ & $11 \%$ & $(07)$ \\
\hline Total & $100 \%(96)$ & $100 \%(159)$ & $100 \%$ & $(63)$ \\
\hline
\end{tabular}




\section{Engineers with Advanced Degrees}

Two-thirds of advanced-degreed engineers show five or fewer years of experience with the company. The remaining one-third are divided equally between $6-10$ and $11+$ length of service groups. While the largest number of advanced-degreed engineers show 5 or fewer years with the company, $44 \%$ are 30-39 years of age. Again the data show that the knowledge base of engineering is more directly related to external sourcing practices than the age of engineers. Male and female engineers with advanced degrees are represented proportionally to their presence in the sample and primary popuiation.

Currentness of Engineering Education

To further characterize the knowledge base of engineers, the investigator completed an analysis of degree completion dates. The data indicate that $69 \%$ of the bachelor degrees were completed in the last 10 years. Similarly $64 \%$ of advanced degrees have been earned within ten years. With the half-life of an engineer's knowledge projected in today's rate of technological change at 3-5 years (Kaufman, 1978), using the degree as one indicator of engineering knowledge, the company could have a $30 \%$ knowledge obsolescence factor unless additional evidence of non-degreed development exists. This rate of obsolescence assumes that the knowledge base gained through engineering-related degrees is effectively utilized in the work environment to minimize knowledge regression.

The data also indicate that the overall formal knowledge-base is relatively current. This shows it has been gained disproportionately 
through recent education. One would conclude that the more recent the knowledge base, the less potential there would be for present knowledge obsolescence. On the other hand, while present liability may be minimized, future liability may be great without continuous development.

TABLE $V$

COMPLETION DATES OF RESPONDENTS' ENGINEERING DEGREES*

\begin{tabular}{llrl}
\hline Degrees & Years & $\%$ & $(\mathrm{n})$ \\
\hline Bachelor's & $1981-85$ & 43.1 & $(60)$ \\
& $1976-80$ & 25.9 & $(36)$ \\
& $1971-75$ & 11.5 & $(16)$ \\
& $1965-70$ & 7.9 & $(11)$ \\
& $1964-$ & 11.5 & $(16)$ \\
Total & & 100 & $(139)$ \\
Advanced & & & \\
& & & \\
& & 39.0 & $(23)$ \\
& $1981-85$ & 25.4 & $(15)$ \\
& $1976-80$ & 20.3 & $(12)$ \\
& $1971-75$ & 10.2 & $(6)$ \\
& $1965-70$ & 5.0 & $(3)$ \\
& 1964 & 100 & $(59)$ \\
\hline
\end{tabular}

*Not all respondents reported completion dates.

Currentness of Education by Length of Service

Degree completion is analyzed in relation to LOS to assess whether or not the development of engineers through education is sustained over time. In the $0-5$ LOS groups $86 \%$ have education 
completed in the last 10 years with $65 \%$ showing completion within the last five. In the 6-10 LOS group, respondent education currency drops to $52 \%$ in the past 10 years with $7 \%$ education completion in the past five. Career engineers (11+) show $26 \%$ completion in the past 10 years with $8 \%$ in the last five.

The data indicate that currentness of education declines with increased service. The potential of knowledge obsolescence as a function of LOS also increases with the percentage of engineers who increasingly report no engineering degrees: $12 \%, 0-5: 36 \%$ in $6-10$ and $53 \%$ in $11 \div$.

The data demonstrate that the majority of engineers do not increase their educational level as a function of their career within the organization. As time passes, engineers rely on initial education for levels of performance and contribution to the organization. Thus, the importance of continuous development through non-degree methods is obvious. The results seem to suggest that the organization has not consistently monitored the education background of engineers since

TABLE VI

COMPLETION DATES OF ENGINEERING DEGREE

FOR LENGTH OF SERVICE GROUPS

\begin{tabular}{|c|c|c|c|c|c|}
\hline & Years & $0-5 \quad(n)$ & $6-10 \quad(n)$ & $11+$ & (n) \\
\hline & $\begin{array}{l}1981-85 \\
1976-80 \\
1971-75 \\
1965-70 \\
1964\end{array}$ & $\begin{array}{r}65.2(77) \\
21.1(25) \\
8.5(10) \\
3.4(4) \\
1.7(2)\end{array}$ & $\begin{array}{r}7.1(3) \\
45.2(19) \\
16.7(7) \\
16.7(7) \\
14.3(6)\end{array}$ & $\begin{array}{r}7.9 \\
18.4 \\
29.0 \\
15.8 \\
29.0\end{array}$ & 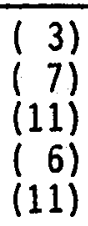 \\
\hline Total & & 100 (118) & $100 \quad(42)$ & 100 & (38) \\
\hline
\end{tabular}


many career engineers have not earned basic engineering degrees or up-dated prior degree work.

Implications for Organization

The hiring behavior of the organization seems to show a trend of increasing the engineering knowledge base of the organization. This trend is marked with an increase of bachelor-degree hiring, resulting in a $26 \%$ presence in the $6-10$ LOS groups to $54 \%$ in the $0-5$ LOS group. This represents a shift of more than $50 \%$. This trend is more powerfully displayed in the hiring of advanced-degreed engineers, changing markedly from a $17.5 \%$ presence in the $6-10$ LOS group to $65 \%$ in the $0-5$ LOS group. However, another possibility exists. Engineers with bachelor and advanced degrees may be showing greater mobility than non-degree engineers. Another trend that is logically occurring simultaneously is the decline in the numbers of recent hires without degrees. The changes are more marked in the LOS groups than in the age groups; this suggests that the link of knowledge/skill is stronger with hiring and sourcing practices initially than with the age of the engineers. Further, the presence of a higher knowledge base in lower LOS groups indicates that longer-term employees may not be up-dating their educational levels over time.

The unequal distribution of engineers across LOS groups may have significant implications related to knowledge obsolescence for the organization. The number of engineers currently in the 0-5 LOS group who have yet to enter the transition and career stage places additional burden on the goal of retention of critical and limited technical 
skill sets of engineers. With high turnover following the fifth and sixth year of empioyment, the organization without paying speciai attention to concerns of the 0-5 LOS population could experience high loss of critical skill sets that are less accessible in the marketplace and that are costly to replace even if available.

The marked differences in education and experience of career employees $(11+)$ and relatively new hires $(0-5)$ could result in work environment conflicts as the organization through its shift in hiring practices is indicating a need for more formal knowledge-based engineering skills to maintain its competitiveness, while a percentage of engineers who have valuable organization experience may not have the required knowledge base. If they did, it would seem reasonable that the organization would hire this internal, more experienced talent rather than doing extensive external sourcing especially with a strong organization policy of internal promotion.

This shift to greater formal background knowledge may have cost implications. Engineers with less formal engineering knowledge but with higher service may be rewarded more than recent hires with current engineering knowledge. As much a problem is the potential of rewarding new, current knowledge-based engineers more than senior, long-term engineers. Persistence of this condition of formal engineering knowledge and service inversion could have negative impact: Engineering costs could be higher than necessary for engineers with high service, but without a needed knowledge-base. The organization also could experience higher turnover of more marketabie and recently educated engineers. Thirdly, the hiring of experienced, 
expert engineers while maintaining long-term engineers without appropriate engineering background reduces the advantage that comes with having the appropriate expertise and organization experience combined. The education data show that the separateness of formal knowledge and length of service currently exists in the company and that the development of career engineers may lag behind business demands.

While the shift to knowledge-based engineers is evident, a potential liability to the organization is the nearly $20 \%$ recently hired (0-5) and young (20-29) engineers without degrees. This potential liability increases dramatically with $36 \%$ of the non-degreed engineers in the 30-39 age group and 31\%, 40 years of age or older. Considering the number of years of continued employment for these nondegreed engineers, the presence of $30 \%$ non-degreed engineers juxtaposed with current hiring practices based on knowledge-needs seems to present a formidable long-term liability to engineering and organizational productivity and effectiveness.

The data also raise questions about the organization's pattern of deveropment. If the present data indeed suggest that development lags knowledge-demand and the organization has recently positioned its present knowledge-base in low LOS groups, one might question where the knowiedge-base for five years from now will come if the past and present development patterns continue. Without high growth in the organization to justify and support external hiring for new knowledgebases, the company could have an adequately-sized engineering population without the needed knowledge--a high knowledge obsolescence and 
low-capability factor. Alternatively, if a pattern of continuous development were instituted especially for engineers with low and moderate LOS, the organization could reduce the negative margin between experience and knowledge-base and leverage engineering capability for the future without peaked hiring for needed skills. With the present policy of employment continuity, the second strategy of continuous development seems critical, unless high organization growth can be assured.

Conclusion

This part of the data analysis investigates the current engineering-related knowledge base in the organization. It seems evident that the organization is increasing hiring standards that result in a more formal knowledge-based engineering population. At the same time the strategy may be diluted by a $30 \%$ population of engineers without degrees cutting across all age and service groups. An examination of education shifts over time indicates that only a small percentage of engineers deveiop tinrough additional degree programs. The development of non-degreed educational opportunities for engineers seems imperative to limit knowledge obsolescence.

\section{Educational Development of Engineers}

In addition to present knowledge base foundations, this study investigates motivation for development and recent educational development activity of the engineers to assess how important learning is to this population and to identify patterns of group differences in 
development methods and activity. A description of respondent information follows with subgroup statistical analysis for significant differences $(p \geq .05)$.

Motivation for Educational Development

Engineers were asked how motivated they were to learn new technical information. On a scale of 1, low and 7, high, overall respondents reported a moderately high (5.4) motivational level. Engineers were asked how important learning new technical information was to their current job and to their career. Again, respondents reported a moderately high level of importance (5.1) for their current job and a higher importance (5.7) for their career.

An analysis of motivation by LOS groups shows no significant differences for learning motivation $\left(x^{2}=2.71\right)$ or the importance of learning to respondents' present job $\left(x^{2}=7.42\right)\left(x^{2}\right.$ required for .05 confidence level with 4 degrees of freedom equals 9.49). However, LOS groups show a significant difference in their value of learning for career their careers $\left(x^{2}=11.91 p>.025\right)$.

TABLE VII

RELATIONSHIP OF EDUCATIONAL DEVELOPMENT TO CAREER LENGTH OF SERVICE GROUPS

\begin{tabular}{lccc}
\hline Rating & $0-5$ & $6-10$ & $11+$ \\
\hline High & $72 \%$ & $66 \%$ & $54 \%$ \\
Moderate & $28 \%$ & $33 \%$ & $42 \%$ \\
Low & 0 & $1 \%$ & $4 \%$ \\
Total & $100 \%$ & $100 \%$ & $100 \%$ \\
\hline
\end{tabular}


The data suggest that the differences lie in the declining relationship of development and careers by the longer-term engineers. (Table VII) The pattern consistently declines from the more recent hires to career engineers.

A similar analysis is completed for education groups with a similar result. No significant differences $(p \geq 05)$ are observed for motivation for learning $\left(x^{2}=5.88 \mathrm{p} \leq .10\right)$ and for importance of learning to present job $\left(x^{2}=5.43 p<.10\right)$. However, education groups also show a significant difference in importance of learning for their career $\left(X^{2}=13.26 \mathrm{p}>01\right)$.

Further investigation (Table VIII) shows that the difference lies primarily with the greater importance of learning for careers reported by engineers with advanced degrees that is higher than non-degreed and bachelor-degreed engineers. The non-degreed and bachelo:-degreed engineers reported little difference in importance of learning for their careers.

\section{TABLE VIII}

RELATIONSHIP OF EDUCATION DEVELOPMENT TO CAREER EDUCATION GROUPS

\begin{tabular}{lccc}
\hline RATING & No Degree & Bachelor's & Advanced \\
\hline High & $57 \%$ & $63 \%$ & $83 \%$ \\
Moderate & $41 \%$ & $35 \%$ & $17 \%$ \\
Low & $2 \%$ & $2 \%$ & 0 \\
Total & $100 \%$ & $100 \%$ & $100 \%$ \\
\hline
\end{tabular}


Educational Development Practices

Respondents provided information on their educational development behavior including course taking, independent reading and networking. Additionally, respondents rated educational development methods for their effectiveness.

Degree-related Development

Twenty-two percent reported that they were currently working on a degree; however, $31 \%$ of the engineers without engineering degrees reported that they were working on a degree.

TABLE IX

DEGREE DEVELOPMENT FOR LENGTH OF SERVICE AND EDUCATION GROUPS

\begin{tabular}{cclll}
\hline Length of Service & $\%(n)$ & Education & $\%(n)$ \\
\hline $0-5$ & $52 \%(36)$ & Non-degreed & $43 \%(30)$ \\
$6-10$ & $30 \%(21)$ & Bachelor's & $49 \%(34)$ \\
$11+$ & $17 \%(12)$ & Advanced & $7 \%(5)$ \\
\hline
\end{tabular}

Thus $21 \%$ of the respondents currently do not have nor are they working on engineering degrees. Currently, the highest degree development activity is reported by engineers with bachelor degrees or $0-5$ years service to the company. The least amount of activity is reported by engineers who already have advanced degrees and who are company career 
engineers $(11+L O S)$. With the low activity of engineers in earning additional degrees to improve and update the knowledge level, the non-degreed development behavior gains in importance.

Non-degree Development

As indicators of non-degree development engineers reported the number of non-degree related courses and seminars taken in the past two years and the amount of time spent reading about technical developments, and networking with other engineers.

Courses and Seminars. The course and seminar information indicates that engineers average one course/seminar per year independent of whether the course/seminar is internal or external. Engineers also report taking more courses internally than externally $\left(x^{2}=21.76 p>001\right)$.

TABLE $X$

NON-DEGREE COURSE AND SEMINAR PARTICIPATION IN PAST TWO YEARS

\begin{tabular}{|c|c|c|c|c|}
\hline & $\% \quad \begin{array}{l}0 \\
\%\end{array}$ & $\% \quad \begin{array}{l}1-2 \\
(n)\end{array}$ & $\%^{3+}$ & (n) \\
\hline Inside Organization & $36 \%(115)$ & $38 \%(122)$ & $26 \%$ & (83) \\
\hline Outside Organization & $51 \%(164)$ & $32 \%(100)$ & $17 \%$ & $(56)$ \\
\hline
\end{tabular}


Significant to the issue of obsolescence is the percentage of engineers who reported taking no courses or seminars the last trio years -- $36 \%$ internally and 51\% outside the organization. To further understand this level of nonparticipation of engineers in courses and seminars, data were examined by education and LOS groups as well as for engineers who are currently working on degrees.

First, course and seminar nonparticipation occurs across all education and LOS groups indicating that encouragement for continuous development is needed independent of prior education and experience. Engineers with bachelor degrees report the highest participation in internal seminars and courses (Table XI).

TABLE XI

NUMBER OF COURSES/SEMINARS TAKEN BY EDUCATION GROUPS IN THE PAST TWO YEARS

\begin{tabular}{|c|c|c|c|}
\hline Education & $\% \quad(n)$ & $\% \frac{1-2}{(n)}$ & $\% \stackrel{3+}{(n)}$ \\
\hline \multicolumn{4}{|c|}{ Inside Organization } \\
\hline Non-degreed & $38 \%(36)$ & $35 \%(33)$ & $27 \%(27)$ \\
\hline Bachel or & $30 \%(48)$ & $40 \%(64)$ & $30 \%(47)$ \\
\hline Advanced & $48 \%(30)$ & $38 \%(24)$ & $14 \%(9)$ \\
\hline \multicolumn{4}{|c|}{ Outside Organization } \\
\hline Non-degreed & $55 \%(53)$ & $29 \%(28)$ & $15 \%(15)$ \\
\hline Bachel or & $49 \%(78)$ & $31 \%(23)$ & $15 \%(9)$ \\
\hline Advanced & $56 \%(35)$ & $37 \%(23)$ & $7 \%(5)$ \\
\hline
\end{tabular}


Non-degreed engineers report $62 \%$ internal participation with advanced-degreed engineers reporting the ieast $52 \%$ participation. Differences among education groups are significant $\left(x^{2}=10.00 p>.05\right)$. Nonparticipation in external courses and seminars occurs independent of educational background $\left(x^{2}=2.63 p<.05\right)$. While participation in internal courses and seminars increases significantly with time in the company from $59 \%(0-5 \mathrm{yrs})$, and $66 \%(6-10 \mathrm{yrs})$ to $70 \%$ $(11+)\left(x^{2}=11.86\right.$ p> .025), external participation remains fairly constant over time $(X 2=1.69 p<.05)$ (Table XII).

TABLE XII NUMBERS OF COURSES/SEMINARS TAKEN BY LENGTH OF SERVICE GROUPS IN THE PAST TWO YEARS

\begin{tabular}{|c|c|c|c|c|}
\hline LOS & $\%^{0}$ & $(n)$ & $\%^{1-2}(n)$ & $\%^{3+}(n)$ \\
\hline \multicolumn{5}{|c|}{ Inside Organization } \\
\hline $0-5$ & $41 \%$ & $(61)$ & $37 \%(54)$ & $22 \%(32)$ \\
\hline $6-10$ & $33 \%$ & (27) & $30 \%(25)$ & $36 \% \quad(31)$ \\
\hline $11+$ & $30 \%$ & (27) & $48 \%(43)$ & $22 \%(20)$ \\
\hline \multicolumn{5}{|c|}{ Outside Organization } \\
\hline $0-5$ & $53 \%$ & (78) & $32 \%(49)$ & $15 \%(22)$ \\
\hline $6-10$ & $52 \%$ & (43) & $29 \%(24)$ & $19 \%(16)$ \\
\hline $11+$ & $48 \%$ & (43) & $33 \%(29)$ & $19 \%(18)$ \\
\hline
\end{tabular}


The greatest percentage of nonparticipation in courses/seminars occurs external to the organization independent of LOS añd education. Overal1, the external nonparticipation rate is $51 \%$ while nonparticipation across LOS and education groups internally is $40 \%$. Of those engineers taking no courses internally, 58\% are also not taking courses externally. Of those taking no outside courses, $41 \%$ indicate that they are not taking any courses internally.

Independent Reading. Respondents reported the number of hours spent reading journals and textbooks per week as yet another indicator of development behavior. Reading behavior averaged 4 hours a week with $40 \%$ of the engineers indicating 2 hours or less. Reading behavior remained relatively constant for non-degreed and bachelordegreed engineers with nearly $50 \%$ reporting a reading level of $0-2$ hours per week (Table XIII). However, degreed (bachelor and advanced)

TABLE XIII

INDEPENDENT READING FOR EDUCATION GROUPS

PER WEEK

\begin{tabular}{|c|c|c|c|}
\hline Education & $\% \quad \begin{array}{l}0-2 \\
(n)\end{array}$ & $\% \quad 3$ & $\% \quad$ (n) \\
\hline Non-degreed & $45 \%(43)$ & $43 \%(41)$ & $12 \%(12)$ \\
\hline Bachelor & $44 \%(71)$ & $34 \%(54)$ & $23 \%(34)$ \\
\hline Advanced & $27 \%(17)$ & $48 \%(30)$ & $25 \%(16)$ \\
\hline
\end{tabular}


engineers reported $11-13 \%$ more reading in the $6+$ hour category than non-degreed engineers. Overall advanced-degreed engineers reported the highest levels of independent reading behavior with $48 \%$ in the 3-5 hour category and $25 \%$ in the $6+$ category. Non-degreed engineers reported the least amount of independent reading. Differences among education groups were significant $\left(x^{2}=11.10\right.$ p $\left.>.025\right)$. Reading behavior for LOS groups showed no significant differences $\left(X^{2}=2.54 p<\right.$ $.05)$.

TABLE XIV

INDEPENDENT READING FOR LENGTH

OF SERVICE GROUPS

\begin{tabular}{llll}
\hline Length of Service & $\%^{0-2}(n)$ & $\%^{3-5}(n)$ & $\%^{6+}(n)$ \\
\hline $0-5$ & $39 \%(57)$ & $39 \%(58)$ & $22 \%(32)$ \\
$6-10$ & $42 \%(34)$ & $37 \%(31)$ & $21 \%(18)$ \\
$11+$ & $45 \%(41)$ & $40 \%(36)$ & $15 \%(13)$ \\
\hline
\end{tabular}

Networking. Information sharing and discussion is an established method for development especially important to innovation (Tushman \& Moore, 1982). The degree of discussion of technical issues is probed at three levels: work group, outside the work group but within the organization, and outside the organization. Ninety-five percent reported weekly discussion of technical issues in their work group at an average rate of 7 hours, with $5 \%$ reporting no discussion of technical issues within their work group. 
Twenty-six percent reported no discussion of technical issues outside of the work group but still in the organization. Those who did report networking outside their work group but still in the organization averaged 2.4 hours weekly. Sixty-one percent of the engineers indicate no networking outside the organization while those who did averaged one hour weekly. No differences $(p=\geq .05)$ across education and length of service groups were found.

Respondents' networking behavior indicates a strong reliance, independent of education and LOS, on their immediate work group for the majority of discussion of new technical developments and issues (Table XXI). The amount of such activity within the work group is diverse. The amount of new information entering work groups from other parts of the organization appears 1 imited. Interaction with engineers outside the organization seems to be minimal. This limited

TABLE XV

TECHNICAL DISCUSSION WITHIN WORK GROUP BY EDUCATION GROUPS

\begin{tabular}{|c|c|c|c|}
\hline Education & $\% \quad$ (n) & $\% \quad \stackrel{5-9}{(n)}$ & $\% \quad \begin{array}{c}10+ \\
\text { (n) }\end{array}$ \\
\hline Non-degreed & $42 \%(40)$ & $31 \%(30)$ & $27 \%(26)$ \\
\hline Bachelor & $37 \%(59)$ & $32 \%(51)$ & $31 \%(49)$ \\
\hline Advanced & $41 \%(26)$ & $27 \%(17)$ & $32 \%(20)$ \\
\hline$x^{2}=1.25, \quad(p<.05)$ & & & \\
\hline
\end{tabular}


interaction and information sharing pattern may isolate the engineers from new developments and directions of other parts of the organization as well as from their competitors and industry. The isolation also may result in missed opportunities for information exchange, innovative synergy, and critical awareness of changes occurring within the organization, the industry and competitors.

TABLE XVI

TECHNICAL DISCUSSION WITHIN WORK GROUPS BY LENGTH OF SERVICE GROUPS

\begin{tabular}{lllll}
\hline Length of Service & $\% \begin{array}{c}0-4 \\
\%\end{array}$ & $\%(n)$ & $\%$ & $\begin{array}{c}10+ \\
(n)\end{array}$ \\
\hline $0-5$ & $35 \%(52)$ & $32 \%(47)$ & $33 \%(48)$ \\
$6-10$ & $35 \%(30)$ & $33 \%(27)$ & $31 \%(26)$ \\
$11+$ & $49 \%(44)$ & $28 \%(25)$ & $23 \%(21)$ \\
$x^{2}=5.10,(p<.05)$ & & & \\
\hline
\end{tabular}

TABLE XVII

NETWORKING ACROSS GROUPS/DIVISIONS

FOR EDUCATION GROUPS

\begin{tabular}{|c|c|c|c|}
\hline Education & $\%^{0}(n)$ & $\% \stackrel{1-2}{(n)}$ & $\%^{3+}(n)$ \\
\hline $\begin{array}{l}\text { Non-degreed } \\
\text { Bachelor } \\
\text { Advanced }\end{array}$ & $\begin{array}{ll}18 \% & (17) \\
29 \% & (45) \\
31 \% & (19)\end{array}$ & $\begin{array}{ll}54 \% & (51) \\
40 \% & (62) \\
48 \% & (30)\end{array}$ & $\begin{array}{ll}28 \% & (27) \\
31 \% & (49) \\
21 \% & (13)\end{array}$ \\
\hline$x^{2}=8.20,(p<.05)$ & & & \\
\hline
\end{tabular}


TABLE XVIII

NETWORKING ACROSS GROUPS/DIVISIONS

FOR LOS GROUPS

\begin{tabular}{llll}
\hline Length of Service & ${ }^{0}$ & $\%^{1-2}$ & $\%^{3+}(n)$ \\
\hline $0-5$ & $30 \%(43)$ & $43 \%(62)$ & $27 \%(40)$ \\
$6-10$ & $25 \%(21)$ & $43 \%(35)$ & $32 \%(26)$ \\
$11+$ & $22 \%(19)$ & $52 \%(46)$ & $26 \%(23)$ \\
$x^{2}=3.27,(p<.05)$ & & & \\
\hline
\end{tabular}

TABLE XIX

NETWORKING OUTSIDE OF ORGANIZATION

FOR EDUCATION GROUPS

\begin{tabular}{|c|c|c|c|}
\hline Education & $q^{0}(n)$ & $\% \quad \frac{1-2}{(n)}$ & $\%{ }^{3+}(n)$ \\
\hline $\begin{array}{l}\text { Non-degreed } \\
\text { Bachelors } \\
\text { Advanced }\end{array}$ & $\begin{array}{ll}65 \% & (62) \\
60 \% & (96) \\
56 \% & (35)\end{array}$ & $\begin{array}{ll}28 \% & (27) \\
27 \% & (43) \\
36 \% & (23)\end{array}$ & $\begin{array}{r}7 \% \\
13 \% \\
13 \% \\
8 \%(20) \\
(5)\end{array}$ \\
\hline$x^{2}=4.50, \quad(p<.05)$ & & & \\
\hline
\end{tabular}

TABLE $X X$

NETWORKING OUTSIDE OF ORGANIZATION

FOR LOS GROUPS

\begin{tabular}{lllll}
\hline Length of Service & $\%^{0}(n)$ & $\%^{1-2}(n)$ & $\%^{3+}(n)$ \\
\hline $0-5$ & $59 \%(87)$ & $28 \%(41)$ & $13 \%(19)$ \\
$6-10$ & $61 \%(51)$ & $33 \%(27)$ & $6 \%(5)$ \\
$11+$ & $63 \%(57)$ & $28 \%(25)$ & $9 \%(8)$ \\
$x^{2}=3.71,(p<.05)$ & & & & \\
\hline
\end{tabular}


TABLE $X X I$

SUMMARY OF NETWORKING BEHAVIOR

\begin{tabular}{lll}
\hline & $M$ & S.D. \\
\hline Work Group & 6.9 & 5.3 \\
Across Organization & 2.4 & 3.3 \\
Outside of Organization & 1 & 2.3 \\
\hline
\end{tabular}

Working on a Degree vs. Not Working on a Degree. In general, an engineer currently working on a degree is as likely to take additional internal courses/seminars as one who is not working on a degree -- $62 \%$ as compared with $65 \%$. However, engineers working on a degree do take fewer additional courses and seminars outside the company. Individuals working on degrees reported higher levels of reading behavior than those not working on degrees. In addition, engineers working on a degree indicate slightly higher networking behavior within the work group and outside of the organization.

Since $78 \%$ of engineers are not working on degrees, their nondegree development behavior is indicative of knowledge obsolescence. With an average of $42 \%$ not taking any additional courses/seminars and reduced amounts of reading and networking behavior, the data suggest that engineers are not participating in development activities on a consistent basis. If the pattern persisted across time, these engineers would be susceptible to knowledge obsolescence that could affect their ability to contribute to the organization. 
TABLE XXII

NON-DEGREE DEVELOPMENT SUMMARY FOR ENGINEERS NOT WORKING ON DEGREES

\begin{tabular}{lcrr}
\hline & \multicolumn{2}{c}{ Courses/Seminars } \\
& 0 & $1-2$ & $3+$ \\
Inside Organization & $35 \%$ & $41 \%$ & $24 \%$ \\
Outside Organization & $49 \%$ & $32 \%$ & $19 \%$ \\
& \multicolumn{4}{c}{ Reading } \\
& $0-2$ & $3-5$ & $6+$ \\
& $44 \%$ & $40 \%$ & $16 \%$ \\
& & & \\
& & Networking & \\
& & & \\
& & & \\
Within Work Group & 6.70 & $6 \%$ at 0 & \\
Across Organization & 2.33 & $17 \%$ at 0 \\
Outside Organization & .89 & $62 \%$ at 0 \\
\hline
\end{tabular}

TABLE XXIII

NON-DEGREE DEVELOPMENT SUMMARY FOR

ENGINEERS IN DEGREE PROGRAMS

\begin{tabular}{llrr}
\hline & \multicolumn{2}{c}{ Courses/Seminars } & \\
& 0 & $1-2$ & $3+$ \\
Inside Organization & $38 \%$ & $29 \%$ & $33 \%$ \\
Outside Organization & $58 \%$ & $27 \%$ & $15 \%$ \\
& \multicolumn{1}{c}{ Independent Reading } & \\
& $0-2$ & $3-5$ & $6+$ \\
& $33 \%$ & $39 \%$ & $28 \%$ \\
& & & \\
& & Networking & \\
& & & \\
& & & \\
Hithin Work Group & 7.64 & $1 \%$ at 0 & \\
Across Organization & 2.64 & $20 \%$ at 0 & \\
Outside Organization & 1.39 & $58 \%$ at 0 & \\
\hline
\end{tabular}


Effective Development Methods

Engineers identified their current development methods. Respondents named reading (45\%) as the most effective method, with $28 \%$ valuing informal discussion or networking, and 15\% preferring courses and seminars. Projects, experiments, tradeshows, and conferences combined for the remaining $12 \%$ of first choice responses.

Engineers also rated various development activities. With an average of $4.73(1,10 w ; 7$, high) for the listed activities, engineers indicated that many methods of development could be useful in improving their knowledge. Challenging work received the highest rating (5.78) followed by reading technical journals (5.48) and earning an advanced degree (5.33). Working in an interdisciplinary project team ranked fourth along with taking an occasional college course. Courses/seminars (within the organization and outside the organization), networking and other reading activities also received above average ratings for effectiveness. Moderate ratings were given to teaching, attending national professional meetings and presenting and publisining papers. Local professional meetings and professional certification were rated lowest as effective methods for remaining technically current.

Education groups showed significant differences $(p \geq 05)$ in reading technical journals $\left(x^{2}=12.14 \mathrm{p}>.025\right)$, working on interdisciplinary project teams $(X 2=14.87 \mathrm{p}>.01)$, attending national professional meetings $\left(X^{2}=16.97 p>01\right)$ and publishing papers $\left(x^{2}=16.10 p>.01\right)$. Advanced-degreed engineers followed by engineers with bachelor degrees rated reading technical journals more effective than non-degree 
engineers. Likewise, advanced-degreed engineers followed by engineers with bachelor degrees responded more positively to interdisciplinary project teams than non-degree engineers. This pattern continues with the effectiveness for development of attending national professional meeting and publishing papers in technical journals. Differences, though not significant for this study $(p \geq .05)$, appeared in attending in-house technical seminars $\left(x^{2}=9.08 p>10\right)$ and presenting papers at professional meetings $\left(x^{2}=8.12 p>.10\right)$. Non-degreed engineers more consistently valued in-house seminars and short courses than engineers with bachelor degrees. Advanced-degreed engineers least valued in-house courses. Degreed engineers also rated giving technical presentations more favorably than the non-degreed engineer. LOS groups reported one significant difference for teaching company seminars $\left(x^{2}=11.17 p>.025\right)$.

Education groups show consistentiy and cumulativeily more differences in their rating of development activities than LOS groups. This suggests that educational background influences choices of development activity and behavior more than length of service. Also, these differences indicate the importance of educational background as a factor in studying knowledge obsolescence. 
TABLE XXIV

EFFECTIVE DEVELOPMENT METHODS

\begin{tabular}{lll}
\hline Method & M & S.D. \\
\hline 1. Challenging Job & 5.78 & 1.07 \\
2. Read Technical Journals & 5.48 & 1.08 \\
3. Advanced Degree & 5.33 & 1.66 \\
4. Occasional College Course & 5.29 & 1.18 \\
5. Interdiscipl inary Project Teams & 5.29 & 1.17 \\
5. Non-company Saminars/Short Courses & 5.23 & 1.14 \\
7. Network in My Organization & 5.21 & 1.19 \\
8. Read Trade Journals/Magazines & 5.08 & 1.18 \\
9. Company Seminars/Short Courses & 5.05 & 1.15 \\
10. Independent Textbook Reading & 5.01 & 1.22 \\
11. Networking with Other Companies & 4.97 & 1.20 \\
12. Teach a College Course & 4.50 & 1.75 \\
13. Teach Company Seminars/Short Courses & 4.38 & 1.64 \\
14. National Professional Meetings & 4.35 & 1.63 \\
15. Present Paper/Professional & 4.07 & 1.56 \\
16. Publish Paper/Journal & 3.94 & 1.66 \\
17. Electronic Database & 3.94 & 1.54 \\
18. Local Professional Meetings & 3.61 & 1.37 \\
19. Professional Certification & 3.30 & 1.72 \\
\hline & & \\
\hline
\end{tabular}




\section{Organizational Barriers to Development}

Engineers were asked to identify three barriers within the organization to getting the information or resources to improve their knowledge and skills. Sixty-two percent of the respondents identified barriers. Twenty percent indicated that time was the primary barrier, followed by cost (12\%), management (9\%), workload (9\%), information/ equipment $(8 \%)$, and library $(4 \%)$. In terms of second and third choices, time remained the primary barrier followed consistently by cost. However, workload and tools overtook the concern about management in the second choice for barriers.

\section{Work Environment for Development}

The study investigated several work environment factors that engineers and engineering managers indicate influence development behavior (Dubin, 1977; Farr et a1., 1980, 1984). Factors explored included: a) organization support for development; b) management c) peer; d) work assignments; e) involvement/communication in decisionmaking; and fl overall climate.

Overal1, peer support received the highest positive response (79\%) with engineer involvement and general climate following at $66 \%$ and $62 \%$ respectively. Management support and work assignments received moderate positive responses at 56\% and 54\%. Engineers gave the lowest positive response to organization support for technical currency at $47 \%$. 
Organization Support for Development

Organization support for technical currency explored the degree that the organization establishes clear technical goals, maintains a competitive market attitude and provides opportunities for engineers to effectively attain goals to meet business objectives. These include job opportunities for continuous growth, tools, rewards for performance, financial support for development opportunities, and guidance for career planning.

Engineers rated the organization low (30\%) in establishing clear technological goals for engineers, but rated the organization moderately high (76\%) in having a competitive market attitude. While the organization appears to provide tools to a majority of engineers (67\%), i.e., effective equipment and facilities, other support systems received modest to marginal ratings at $50 \%$ or less. Only $43 \%$ indicated that the organization's performance system rewards technical competence; $45 \%$ thought that the organization is open to innovation with $54 \%$ of the engineers viewing the organization as a recognized innovator. Less than $50 \%$ of the respondents indicated that job rotation is practiced to allow exposure to new disciplines. Just over half $(52 \%)$ indicated that budgets included funds for development. While financial support is available to the majority for professional meetings (69\%), budgets for journals are funded at $50 \%$. Lowest ratings went to recognition for development (32\%) and career planning $(23 \%)$. 
TABLE XXV

ORGANIZATION SUPPORT FOR DEVELOPMENT

\begin{tabular}{|c|c|c|c|}
\hline - Agrees-No & $\begin{array}{l}\text { Opinion-Disagrees } \\
\text { Percentages }\end{array}$ & $\underline{M}$ & S.D. \\
\hline 1. Competitive Market Attitude & $76-12-12$ & 5.17 & 1.28 \\
\hline $\begin{array}{l}\text { 2. Payment for Professional } \\
\text { Meetings }\end{array}$ & $69-13-18$ & 4.91 & 1.51 \\
\hline $\begin{array}{l}\text { 3. Tools/Current Technical } \\
\text { Equipment/ Facilities }\end{array}$ & $67-5-28$ & 4.58 & 1.62 \\
\hline 4. Recognized Innovator & $54-14-32$ & 4.25 & 1.38 \\
\hline $\begin{array}{l}\text { 5. Project Budgets Fund } \\
\text { Technical Updating }\end{array}$ & $52-16-32$ & 4.48 & 1.93 \\
\hline $\begin{array}{l}\text { 6. Payment for Journal } \\
\text { Subscription }\end{array}$ & $50-19-31$ & 4.20 & $\begin{array}{l}6 . \\
1.86\end{array}$ \\
\hline $\begin{array}{l}\text { 7. Job Rotation for Exposure to } \\
\text { New Disciplines }\end{array}$ & $47-28-25$ & 4.35 & 1.45 \\
\hline $\begin{array}{l}\text { 8. Company Involved in } \\
\text { Technical Dynamic Fields }\end{array}$ & $47-24-28$ & 4.41 & 1.47 \\
\hline 9. Company Openness to Innovation & $45-19-35$ & 4.13 & 1.45 \\
\hline $\begin{array}{l}\text { 10. Performance System that Rewards } \\
\text { Technical Competence }\end{array}$ & $43-13-44$ & 3.81 & 1.71 \\
\hline $\begin{array}{l}\text { 11. Recognition for Advanced } \\
\text { Training/Degrees }\end{array}$ & $32-35-32$ & 3.92 & 1.29 \\
\hline 12. Clear Technical Goals & $30-25-45$ & 3.69 & 1.51 \\
\hline 13. Career Guidance & $23-33-44$ & 3.50 & 1.54 \\
\hline Average Totals & $49-20-31$ & 4.26 & 1.54 \\
\hline
\end{tabular}


Education groups reported significant differences for organizational support. Advanced-degreed engineers indicate greater satisfaction but al so the greatest variance with technical equipment and facilities ( $\left.X^{2}=10.75, p>.05\right)$. Likewise, advanced-degreed engineers report greater financial support for professional meetings $\left(x^{2}=10.80\right.$, p>.05) than engineers of other education groups. In contrast, nondegreed engineers report the greatest amount of career guidance, with the least amount reported by advanced-degreed engineers $\left(x^{2}=20.33\right.$ p>.001). Non-degreed engineers al so indicate more opportunity for job rotation, with the least amount available to advanced-degreed engineers $\left(x^{2}=12.72 p>025\right)$. Education groups al so indicate differences (p>.10) in support for clear technology goals, recognition for training and development, and payment for journals $\left(x^{2}=8.32,8.98,9.41\right.$ respectively).

LOS groups reported no significant differences $(p>.05)$ for organization support.

Management Support for Development

The manager support factor investigated the extent that managers establish performance goals, actively encourage career development, solicit ideas, share information, set goals, and reward appropriate behavior.

Engineers rated managers highest (76\%) in eliciting ideas from engineers. Engineers gave moderate positive responses to managers involvement of engineers in establishing performance goals (65\%), discussion of technical problems and developments (62\%), and providing feedback for continuous improvement during performance reviews (61\%). 
Engineers also gave moderate positive response (64\%) for salary and promotions based on technicai performance and opportunities for attending seminars/courses (63\%) and professional meetings (62\%). Engineers rated management low in encouraging technical reading and presentations (48\% and $38 \%$ respectively). Engineers also rated managers low in recognizing and rewarding their efforts to keep technically current (40\%) and in providing career guidance (31\%) (Table XXVI).

An analysis of education groups resulted in two elements of significant differences $(p \geq .05)$. Non-degreed and bachelor-degreed engineers report less support for doing technical presentations $\left(X^{2}=10.73 p>.05\right)$ than advanced-degreed engineers. Secondiy, advanced-degreed engineers indicate less support for independent reading during working hours than the other engineers $\left(x^{2}=19.27 \mathrm{p}>0001\right)$. Advanced-degreed engineeers, though not significant, report higher levels of support for attending professional meetings than bachelordegreed engineers, who in turn were more highly supported than non-degreed engineers $\left(x^{2}=8.48 p>.10\right)$. Across LOS groups, however, support for attending professional meetings showed significant differences $\left(x^{2}=15.50\right.$ p $\left.>01\right)$. Engineers with service of 5 or fewer years reported higher levels of support than engineers with 6-10 and $11+$ years of service. 
TABLE XXVI

MANAGER SUPPORT FOR DEVELOPMENT

\begin{tabular}{|c|c|c|c|}
\hline $\begin{array}{r}\text { Agrees-No Op } \\
\text { Per }\end{array}$ & $\begin{array}{l}\text { pinion-Disagrees } \\
\text { rcentages }\end{array}$ & $\underline{M}$ & S.D. \\
\hline $\begin{array}{l}\text { 1. Elicits Ideas about } \\
\text { Technical Problems }\end{array}$ & $76-11-13$ & 5.17 & 1.35 \\
\hline 2. Current Knowledge of Manager & $67-8-26$ & 4.71 & 1.67 \\
\hline 3. Sets Performance Goals & $65-10-25$ & 4.76 & 1.64 \\
\hline $\begin{array}{l}\text { 4. Provides Salary and Promotion } \\
\text { for Technical Performance }\end{array}$ & $61-22-17$ & 4.69 & 1.31 \\
\hline $\begin{array}{l}\text { 5. Provides Opportunity for } \\
\text { Attending Professional Meetings }\end{array}$ & $63-19-18$ & 4.93 & 1.52 \\
\hline $\begin{array}{l}\text { 6. Provides Opportunity for } \\
\text { Attending Courses/Seminars }\end{array}$ & $62-10-28$ & 4.53 & 1.65 \\
\hline $\begin{array}{l}\text { 7. Discusses Technical Issues } \\
\text { /Developments }\end{array}$ & $62-6-32$ & 4.59 & 1.89 \\
\hline $\begin{array}{l}\text { 8. Does Performance Review for } \\
\text { Continued Improvement }\end{array}$ & $61-22-17$ & 4.75 & 1.37 \\
\hline $\begin{array}{l}\text { 9. Encourage Technical Reading during } \\
\text { Working Hours }\end{array}$ & $48-30-23$ & 4.38 & 1.36 \\
\hline $\begin{array}{l}10 \text { Recognizes/Rewards Technical } \\
\text { Development }\end{array}$ & $40-27-33$ & 3.98 & 1.31 \\
\hline 11. Encourages Technical Presentations & $38-31-31$ & 4.11 & 1.60 \\
\hline 12. Provides Career Guidance & $32-22-46$ & 3.62 & 1.56 \\
\hline Average Totals & $56-18-26$ & 4. 52 & 1.52 \\
\hline
\end{tabular}




\section{Peer Support}

Ât $79 \%$, peer support was the most highly rated work environment factor. Engineers rated peers as good sounding boards for new ideas (93\%), indicated that they provided reliable information (82\%) and encouraged each other in remaining technically current (85\%). In general, they share ideas (63\%) and materials (78\%) and provide feedback for work improvement (78\%).

TABLE XXYII

PEER SUPPORT

\begin{tabular}{|c|c|c|c|}
\hline \multicolumn{2}{|c|}{$\begin{array}{c}\text { Agree-No Opinion-Disagree } \\
\text { Percentage }\end{array}$} & $M$ & S.D. \\
\hline 1. Act as Sound Boards & $93-4-3$ & 5.84 & .93 \\
\hline $\begin{array}{l}\text { 2. Encourage Each Other in } \\
\text { Remaining Technically Current }\end{array}$ & $85-8-7$ & 5.88 & 1.32 \\
\hline $\begin{array}{l}\text { 3. Serve as Reliable Information } \\
\text { Source }\end{array}$ & $82-9-9$ & 5.18 & 1.05 \\
\hline $\begin{array}{l}\text { 4. Share Journal Articles and } \\
\text { Papers }\end{array}$ & $78-6-16$ & 5.03 & 1.30 \\
\hline $\begin{array}{l}\text { 5. Provide Feedback to Improve } \\
\text { Designs }\end{array}$ & $78-9-13$ & 5.10 & 1.25 \\
\hline $\begin{array}{l}\text { 6. Respond Positively to New } \\
\text { Ideas }\end{array}$ & $72-8-20$ & 5.09 & 1.48 \\
\hline 7. Share Ideas & $63-25-12$ & 4.87 & 1.13 \\
\hline Average Totals & $79-10-11$ & 5.28 & 1.21 \\
\hline
\end{tabular}


Education groups, however, reported a significant difference in engineers sharing ideas $\left(x^{2}=10.51 p>.05\right)$ and identifying errors in design and ideas $\left(x^{2}=12.48 p>025\right)$. Non-degreed engineers indicated a more moderate response, followed by advanced-degreed engineers with engineers having bachelor degrees showing the greatest peer support in these areas. LOS groups showed no significant peer support differences.

\section{Work Assignments}

The work assignment factor explored the extent that engineers are assigned work that is interesting, challenging and nonrepetitive. Seventy-four percent of the engineers indicated that challenging work is given to engineers independent of length of service to the company. However, only 53\% thought that jobs stretched the engineer's knowledge with $48 \%$ indicating that assignments are frequently repetitious and formatted. Further, 57\% indicated that engineers are often assigned to non-technical tasks with $41 \%$ reporting that engineers are not always hired for engineering jobs. Sixty-fiye percent did indicate that assignments are made in the engineer's personal interest area when possible. Also, 60\% indicated that their jobs allow time for exploring new ideas.

Both education and LOS groups report elements of significant differences, though the elements are different for the groups. Advanced-degreed engineers report work assignments with more state of art technology than other education groups $\left(X^{2}=10.19 p>05\right)$. Further, advanced-degreed engineers indicate a closer relationship of 
their job and personal interest, with non-degreed engineers reporting the least relationship $\left(X^{2}=15.25\right.$ p $\left.>01\right)$.

Among LOS groups longer term employees report more non-technical tasks in their work $\left(X^{2}=9.58\right.$ p>.05). Engineers with less company experience consistently report assignments where no technological change is occurring ( $\left.X^{2}=18.34 p>01\right)$.

TABLE XXVIII

WORK ASSIGNMENTS

\begin{tabular}{llll}
\hline & Agrees-No $\begin{array}{c}\text { Opinion-Disagrees } \\
\text { Percentages }\end{array}$ & M & S.D. \\
\hline $\begin{array}{l}\text { 1. Challenging Work Assigned } \\
\text { Independent of LOS }\end{array}$ & $74-20-8$ & 5.28 & 1.29 \\
2. Include State of Art Technology & $70-6-24$ & 4.87 & 1.51 \\
3. Are of Personal Interest & $65-19-16$ & 4.72 & 1.27 \\
4. Allow Time for Exploring New Ideas & $60-4-36$ & 4.30 & 1.69 \\
5. Involve Technical Tasks & $29-14-57$ & 3.43 & 1.61 \\
6. Stretch Technical Knowl edge & $53-11-36$ & 4.24 & 1.52 \\
7. Non Repetitive/Formatted & $48-21-30$ & 4.27 & 1.39 \\
8. Jobs in Area of Technology Change & $34-41-26$ & 4.16 & 1.26 \\
Average Totals & $54-16-30$ & 4.44 & 1.47 \\
\hline
\end{tabular}

Invol vement/Communication

Engineers rated the degree of open information exchange among engineers and management and the extent that project decisions are decentralized. Engineers gave the highest rating to involvement in technical decisions relevant to their assignments (86\%). They gave 
the lowest rating to the degree of open communication between engineers and company management (44\%). Sixty-four percent indicated that engineers have a sense of personal involvement in the company's future. Seventy-four percent did not feel that competition among engineers restricted information exchange; $58 \%$ indicated that proprietary information did not restrict interaction with engineers. Over two-thirds $(68 \%)$ indicated that supervisors encourage communication and sharing of information among engineers.

TABLE XXIX

INVOLVEMENT/COMMUNICATION

\begin{tabular}{|c|c|c|c|}
\hline Agrees-No & $\begin{array}{l}\text { Opinion-Disagrees } \\
\text { Percentage }\end{array}$ & $\underline{M}$ & S.D. \\
\hline $\begin{array}{l}\text { 1. Participate in Decisions Relate } \\
\text { to Job Assignments }\end{array}$ & $86-4-0$ & 5.37 & 1.15 \\
\hline $\begin{array}{l}\text { 2. Information Exchange is not } \\
\text { Restricted by Excessive } \\
\text { Competition Among Engineers }\end{array}$ & $74-12-14$ & 5.22 & 1.38 \\
\hline $\begin{array}{l}\text { 3. Supervisor Shares Information } \\
\text { Encourages Communication among } \\
\text { the Engineers }\end{array}$ & $68-11-21$ & 4.82 & 1.51 \\
\hline $\begin{array}{l}\text { 4. Sense of Personal Involvement } \\
\text { in Future of Company }\end{array}$ & $64-9-26$ & 4.57 & 1.47 \\
\hline $\begin{array}{l}\text { 5. Information Exchange is not } \\
\text { Restricted by Concern for } \\
\text { Proprietary Information }\end{array}$ & $58-25-17$ & 4.75 & 1.34 \\
\hline $\begin{array}{l}\text { 6. Communication is Open between } \\
\text { Company Management and } \\
\text { Engineers }\end{array}$ & $44-15-41$ & 3.91 & 1.58 \\
\hline Average Totals & $66-13-21$ & 4.77 & 1.41 \\
\hline
\end{tabular}


The LOS groups reported more significant differences than the education groups for engineer involvement and communication. Consistently longer-service employees reported declining levels of participation in decision-making $\left(x^{2}=10.23 p>.05\right)$ and less total project understanding directed by supervisor $\left(x^{2}=12.28 p>.025\right)$. Additionally, though not significant for this study, engineers with 6-10 years of service had less personal involvement with the company than engineers with less service and more service than they $\left(X^{2}=9.10\right.$ p> .10). Both non-degreed and engineers with bachelor degrees reported less participation in decision-making than advanced-degreed engineers $\left(X^{2}=11.68 p>.025\right)$.

Climate

Climate examined the degree that the "atmosphere" of the organization fosters personal and professional growth, technical creativity and innovation, and high performance. The highest rating (77\%) went to job security followed by company concern for professional growth (73\%) and a positive attitude toward innovation and excellence $(71 \%)$. However, only $59 \%$ indicated a high value of development of engineers. Sixty-one percent indicated that the organization recognized the technical contribution of its engineers with 55\% reporting that rewards were given to technically competent engineers.

LOS groups showed a significant difference $(p>.05)$ on the organization's value of engineering development $\left(x^{2}=11.02, p>05\right)$. The 6-10 LOS group accounted for the majority of the difference with a 
lower perceived value for engineering development. Al though not significant for this study, LOS groups also indicated a difference in professional standards $\left(x^{2}=8.11\right.$ p $\left.>.10\right)$. Again, $0-5$ and $11+$ LOS groups believed that the organization stresses high professional standards more than the 6-10 LOS engineers.

Education groups showed no significant differences in climate at the .05 level but showed difference $\left(x^{2}=8.35 p>.10\right)$ for the organization's

TABLE XXX

CLIMATE

\begin{tabular}{|c|c|c|c|}
\hline Agree-No- & $\begin{array}{l}\text { pinion-Disagree } \\
\text { Percentage }\end{array}$ & $M$ & SD \\
\hline 1. Provides Employment Continuity & $77-17-6$ & 5.27 & 1.16 \\
\hline 2. Concern for Professional Growth & $73-9-18$ & 4.91 & 1.41 \\
\hline $\begin{array}{l}\text { 3. Encourages Innovation } \\
\text { and Excellence }\end{array}$ & $71-11-18$ & 5.02 & 1.47 \\
\hline $\begin{array}{l}\text { 4. Utilizes Technical Knowiedge } \\
\text { Effectively }\end{array}$ & $69-6-25$ & 4.85 & 1.47 \\
\hline $\begin{array}{l}\text { 5. Stresses High Professional } \\
\text { Standards }\end{array}$ & $67-15-18$ & 4.77 & 1.30 \\
\hline $\begin{array}{l}\text { 6. Encourages, Creativity and } \\
\text { Growth }\end{array}$ & $61-11-28$ & 4.63 & 1.57 \\
\hline $\begin{array}{l}\text { 7. Recognizes of Technical } \\
\text { Contribution }\end{array}$ & $61-17-22$ & 4.58 & 1.39 \\
\hline 8. Values Development of Engineers & $59-14-27$ & 4.57 & 1.40 \\
\hline 9. Rewards for Technical Competence & $55-18-27$ & 4.36 & 1.43 \\
\hline Total Averages & $66-13-21$ & 4.77 & 1.39 \\
\hline
\end{tabular}


concern for the growth of engineers. While non-degreed engineers reporied the highest level of organization concern for growth, advanced-degreed engineers reported the greatest variance. Engineers with bachelor degrees reported the least organization concern for development.

Conclusion

A climate for development of engineers stresses several key elements:

1. An overall atmosphere, expectation, and fostering of innovation, excellence and growth driven by competitive benchmarks from the market environment. 2. Challenging work that effectively utilizes the expertise of the individual and increases the individual's current knowledge base. 3. Performance and reward structures linked effectively to development and performance i.e. overall individual competence. 4. Management and peer relationships that provide a collegial environment for growth through high performance goals, sharing of expertise and new information, and continuous feeddback. 5. Opportunities, support and recognition for development as an integral element of performance.

In this section the investigator examined the work environment to gain insights about the degree that these elements exist. Work environment elements were examined for differences across education and LOS groups. The work environment results in this study indicate a moderate climate with considerable variance for development. The variance across the factors suggests that the development climate within the company is inconsistent. While about two-thirds of the 
engineers indicate a positive work environment, consistently $20-30 \%$ do not. This is particularly evident in challenging work and reward and recognition. Work assignments and organization support for development show the greatest opportunity for improvement. Peer support provides a strength in the climate not only for its high response but for the consistency of response.

TABLE XXXI

WORK ENVIRONMENT SUMMARY

\begin{tabular}{lccccc}
\hline & Agree & No Opinion & Disagree & M & SD \\
\hline Peer Support & 79 & 10 & 11 & 5.28 & 1.21 \\
Climate & 66 & 13 & 21 & 4.77 & 1.39 \\
Invol vement/Communication & 66 & 13 & 21 & 4.77 & 1.41 \\
Management Support & 56 & 18 & 26 & 4.52 & 1.52 \\
Work Assignments & 54 & 16 & 30 & 4.44 & 1.47 \\
Company Support & 49 & 20 & 31 & 4.26 & 1.54 \\
Total Averages & 62 & 15 & 23 & 4.67 & 1.42 \\
\hline
\end{tabular}


The greatest degree of significant differences for education groups occurred in the organization support factor with variance related to technical equipment and facilities, financial support for professional meetings, career guidance and opportunity for job rotation. Management support differences for education groups involved opportunity for technical presentations and independent reading during work hours. Work assignment differences focused on state of art technology and personal interest. Peer support differences occurred with sharing ideas and providing feedback.

For LOS groups key differences in work assignments involved the amount of non-technical work assigned and the degree of technological change occurring in product area. LOS groups showed differences in climate as far as the organization value of the development of engineers and management support for attending professional meetings. Significant differences in supervisor sharing of information occurred in LOS groups, with both education and LOS groups showing differences for participation in decision making. Overall more cumulative differences were observed across education groups than LOS groups.

\section{Rewards}

\section{Reward Preferences}

The reward environment and its relationship to development was explored more in depth. Engineers selected ten reward preferences and rated how important the rewards were to them. Respondents chose salary and merit increases (87\%), achievement from work (83\%), 
advancement (76\%), recognition (76\%) and challenging work (69\%) as most important (Table XXXII). Just over $50 \%$ of the respondents selected self-initiative (58\%), supervisor relations (56\%), job security (54\%), peer relations (53\%), and encouragement or ability (52\%) as important rewards. All other rewards were selected by less than $50 \%$ of the respondents. As potential rewards were selected less often, their overall importance to respondents also declined.

By education and LOS groups the selection of some rewards differed significantly. Educational group differences occurred for customer satisfaction $\left(X^{2}=8.99\right.$ p>.05), challenging work assignments $\left(x^{2}=8.40 p>05\right)$, job security $\left(x^{2}=10.34 p>.025\right)$ and support for writing technical articles $\left.\left(X^{2}=8.81 \mathrm{p}\right\rangle .05\right)$. Customer satisfaction was less important to advanced-degreed engineers, while most important to non-degreed engineers. Engineers with bachelor degrees selected challenging work more often than non-degreed and advanced-degreed engineers. Job security was selected more often by non-degreed engineers than degreed engineers. Support for writing appealed to advanceddegreed engineers more than bachelor and non-degreed engineers. 
TABLE XXXII

RANKING OF RENARD PREFERENCES

\begin{tabular}{|c|c|c|c|}
\hline $\begin{array}{l}\text { Perc } \\
\text { Impo }\end{array}$ & $\begin{array}{l}\text { centage } \\
\text { ortant }\end{array}$ & $\begin{array}{c}\text { How } \\
\text { Mean }\end{array}$ & $\begin{array}{l}\text { ant } \\
\text { S.D. }\end{array}$ \\
\hline $\begin{array}{l}\text { 1. Salary/Merit Increase } \\
\text { 2. Achievement } \\
\text { 3. Recognition } \\
\text { 4. Advancement } \\
\text { 5. Challenging Work } \\
\text { 6. Initiative in Work } \\
\text { 7. Positive Supervisor } \\
\text { 8elations } \\
\text { 8. Job Security } \\
\text { 9. Positive Peer Relations } \\
\text { 10. Encoragement of Innovative/ } \\
\text { Ability } \\
\text { 11. Customer Satisfaction } \\
\text { 12. Development Support } \\
\text { 13. Knowledge of Whole Project } \\
\text { 14. Major Project Responsibility } \\
\text { 15. Leading Edge Tech. } \\
\text { Assignment } \\
\text { 16. Company Reputation for } \\
\text { Technical Excellence } \\
\text { 17. Consultant Role Internal } \\
\text { 18. Support for Prof. } \\
\text { Memberships } \\
\text { 19. Technica! Library } \\
\text { 20. More Non-work Related Time } \\
\text { 21. Mentor Role } \\
\text { 22. Support for Publication }\end{array}$ & $\begin{array}{l}56 \\
54 \\
53 \\
\\
52 \\
48 \\
44 \\
34 \\
33 \\
\\
32 \\
24 \\
20\end{array}$ & $\begin{array}{l}5.80 \\
6.13 \\
5.66 \\
5.86 \\
5.79 \\
5.57 \\
5.39 \\
5.49 \\
5.61 \\
5.60 \\
5.66 \\
5.39 \\
5.21 \\
5.26 \\
5.29\end{array}$ & $\begin{array}{l}1.28 \\
1.40 \\
1.21 \\
1.73 \\
1.12 \\
.93 \\
1.12 \\
1.34\end{array}$ \\
\hline
\end{tabular}

In the LOS groups career employees (11+ years) selected job security significantly more often $\left(x^{2}=12.32 p>.01\right)$ than other LOS groups with 6-10 year service engineers selecting it least often. 
In contrast to differences across education and LOS groups for selecting rewards, these same groups show no significant differences $(p=>05)$ in the value of the ten most preferred rewards.

Relationship of Preferred Rewards to Development

The majority of engineers indicate that they would receive valued rewards if their knowledge and skills remained the same for the next two years (Table XXXIII). An average of twenty-one percent reported strong opportunity for rewards independent of development with an average of $59 \%$ demonstrating a moderate belief of opportunity for rewards without development. Only 20\% across key rewards indicated 1ittle opportunity for rewards without development. On the other hand, engineers consistently believed that the opportunity for valued rewards improved if development occurred (TABLE XXXIV).

When asked if engineers would receive their preferred rewards if technically up-to-date, significant differences occurred for 3 of the 10 most preferred rewards in LOS groups. Consistentiy, longer-service employees indicated that they had less chance of being recognized $\left(X^{2}=10.86 p>.05\right)$, receiving advancement $\left(X^{2}=11.31 p>.05\right)$, and earning salary and merit increases $\left(X^{2}=19.51 p>001\right)$. Al so, a sense of achievement from work, though not significant, showed the same declining trend over time $\left(X^{2}=9.07 p>.10\right)$. These data suggest that three key rewards of engineers are less related to development as service company increases. Education groups showed a significant difference $\left(X^{2}=13.41 p>01\right)$ of the relationship of development to 
to challenging work with degreed engineers indicating that challenging work would be available more often if they were technically current than non-degree engineers.

TABLE XXXIII

OPPORTUNITY FOR RENARD/SAME SKILLS

\begin{tabular}{|c|c|c|c|c|c|}
\hline Rewards & High & $\begin{array}{l}\text { Percentage } \\
\text { Moderate }\end{array}$ & Low & $M$ & SD \\
\hline 1. Salary/Merit Increase & 17 & 64 & 19 & 3.94 & 1.58 \\
\hline 2. Achievement & 22 & 58 & 20 & 4.13 & 1.70 \\
\hline 3. Recognition & 15 & 61 & 26 & 3.68 & 1.63 \\
\hline 4. Advancement & 13 & 58 & 29 & 3.62 & 1.62 \\
\hline 5. Challenging Work & 17 & 56 & 25 & 3.72 & 1.59 \\
\hline 6. Initiative & 25 & 57 & 19 & 4.21 & 1.67 \\
\hline 7. Supervisory Relations & 28 & 56 & 16 & 4.30 & 1.73 \\
\hline 8, Job Security & 25 & 62 & 14 & 4.36 & 1.57 \\
\hline 9. Peer Relations & 40 & 53 & 6 & 4.85 & 1.51 \\
\hline $\begin{array}{l}\text { 10. Encouragement of } \\
\text { Innovative Ability }\end{array}$ & 11 & 60 & 29 & 3.52 & 1.60 \\
\hline Average Totals & 21 & 59 & 20 & 4.04 & 1.46 \\
\hline
\end{tabular}


TABLE XXXIV

OPPORTUNITY FOR RENARD/IMPROVED SKILLS

\begin{tabular}{|c|c|c|c|c|c|}
\hline Rewards & High & Moderate & Low & $M$ & SD \\
\hline 1. Salary/Merit Increase & 55 & 40 & 6 & 5.41 & 1.49 \\
\hline 2. Achievement & 65 & 34 & 2 & 5.68 & 1.18 \\
\hline 3. Recognition & 55 & 39 & 6 & 5.36 & 1.42 \\
\hline 4. Advancement & 53 & 39 & 9 & 5.24 & 1.56 \\
\hline 5. Challenging Work & 56 & 39 & 4 & 5.43 & 1.31 \\
\hline 6. Initiative & 60 & 37 & 3 & 5.55 & 1.32 \\
\hline 7. Supervisory Relations & 61 & 34 & 5 & 5.43 & 1.45 \\
\hline 8. Job Security & 52 & 43 & 4 & 5.39 & 1.39 \\
\hline 9. Peer Relations & 64 & 33 & 3 & 5.60 & 1.23 \\
\hline $\begin{array}{l}\text { 10. Encouragement of } \\
\text { Innovative Ability }\end{array}$ & 49 & 44 & 7 & 5.01 & 1.53 \\
\hline Average Totals & 57 & 38 & 5 & 5.41 & 1.39 \\
\hline
\end{tabular}


Analysis of Group Differences

Results of the chi-square analysis for items have been reported throughout the study. The item analysis was done to probe where differences might occur within the primary categories of the study: development motivation and behavior, development activities, work climate, preferred rewards and their relationship to development. To respond to the null hypotheses of the study, the total comparisons and the number of differences expected relative to the number found for each category have been analyzed (Table XXXV). Additionally, the number of differences indicated at the .01 level have been identified.

TABLE XXXV

GROUP DIFFERENCES

\begin{tabular}{lccc}
\hline Variable & $\begin{array}{c}\text { Number of Expected } \\
\text { Differences (.05) }\end{array}$ & $\begin{array}{c}\text { Number of } \\
\text { Differences } \\
\text { Education }\end{array}$ & $\begin{array}{c}\text { Found } \\
\text { LOS }\end{array}$ \\
\hline $\begin{array}{l}\text { 1. Development Behavior } \\
\text { Degree } \\
\text { Nondegree }\end{array}$ & .05 & 1 & 1 \\
& .9 & 2 & 1 \\
2. Work Climate & 8.3 & $11 *$ & $6 * *$ \\
$\begin{array}{l}\text { 3. Reward Preference } \\
\begin{array}{l}\text { 4. Opportunity for Reward } \\
\text { with Improved Skills }\end{array}\end{array}$ & 3.3 & 4 & $1 * * *$ \\
$\begin{array}{l}\text { 5. Learning Methods } \\
\text { Total }\end{array}$ & 1.5 & $1 * * *$ & $3 * * * *$ \\
\hline
\end{tabular}

$\star 3$ at .01

$* * 2$ at .01

$\star \star \star 1$ at .01

$\star \star \star \star 1$ at .001

$\star \star \star \star \star * 3$ at .01 
Development Behavior

The data show that the number of differences found for development behavior exceed what was expected for .05 significance for education and LOS groups but only modestly so. No differences occurred at the .01 level. Therefore, the null hypotheses for development behavior for both LOS and education groups are accepted.

Work Climate

Education groups exceed the number of expected differences for .05 level of significance with three differences reported at the .01 level of significance. However, since the number of differences exceeding that expected were few the nuli hypothesis for education groups and work climate is accepted. Length of service groups had fewer differences than expected; therefore, the nul1 hypothesis is accepted for work climate and length of service groups.

Reward Preference

The number of differences found for education groups exceed that expected for .05 level of significance while differences for length of service groups did not. Nevertheless the differences exceeding that expected for education groups were few in number, the null hypotheses for reward preferences are accepted for education groups and accepted for both education and length of service groups.

Opportunity for Reward with Improved Skills

The number of differences found for length of service groups exceed that expected, while the number for education groups do not. 
The number exceeding that expected for length of service groups, however, were insufficint to reject the null hypothesis. Therefore the hypotheses for opportunity for reward with improved skills for education and length of service groups are accepted.

Learning Methods

The number of differences for preferred learning methods by education groups exceed that expected with the majority of difference occurring at the .01 level. Since only one difference exceeded that expected, the null hypothesis is accpeted. Length of service groups report fewer differences than expected; the null hypothesis is also accepted for preferred learning methods of length of service groups. 


\section{CHAPTER V}

SUMMARY, CONCLUSIONS, RECOMMENDATIONS

\section{Introduction}

Present and future organizations increasingly confronted by dynamic, uncertain environments must develop and maintain adaptable, responsive, and flexible structures and processes to survive in an era of rapid, uneven change. Continuous change and renewal will determine the survivors--those organizations that recognize and accept the challenge of "human systems in transition" (Lippitt, 1982). Human resource development at individual, group, and organizational levels will provide the capability of organizations to complete the necessary and ongoing transformation of the late 20th and early 21st century. Knowledge obsolescence, the focus of this study, is but one of the challenges confronting today's organizations. Knowledge and skills come to organizations through people--individuals whose knowledge and skills contribute to the achievement of organizational objectives. With rapid change, it is increasingly difficult to forecast, to develop and to integrate the knowledge and skills needed to achieve changing organizational objectives.

While development of organizations in the past has focused primarily on group and organizational processes to improve productivity 
and performance, the impact of knowledge obsolescence on organizational performance, productivity, and future capability now brings individual development to the forefront. With essential knowledge and skills changing rapidly, the 1 iability to the organization of not managing knowledge development increases exponentially. Work design and organizational programs can only motivate, optimize and synergize the relevance and quality of knowledge and skills possessed by individuals. Thus, continuous individual development forms the foundation for subsequent group and organizational development strategies.

Organizational leaders must recognize that the degree of knowledge development, like performance in general, is influenced not only by individual attitude and ability but by the nature of work and the total organizational environment. Thus, knowledge development occurs not in a vacuum but in concert with all other conditions and relationships that the individuat and organization share.

Sunmary

Purpose

The purpose of this study is to investigate knowledge obsolescence in an organization influenced by rapid change in its environment. Key assumptions of the study emphasize that people are assets to organizations and that people exert effort for the organization in exchange for valued rewards. Therefore, the member-organization relationship is mutually beneficial, requiring both organization and member to be sensitive and responsive to demands, constraints, and op- 
portunities. Finally, the study assumes that a holistic approach to studying organizational issues captures the complexity and interdependence of organizational subsystems that in turn influence the achievement of organizational objectives. (See Figure 7 ).

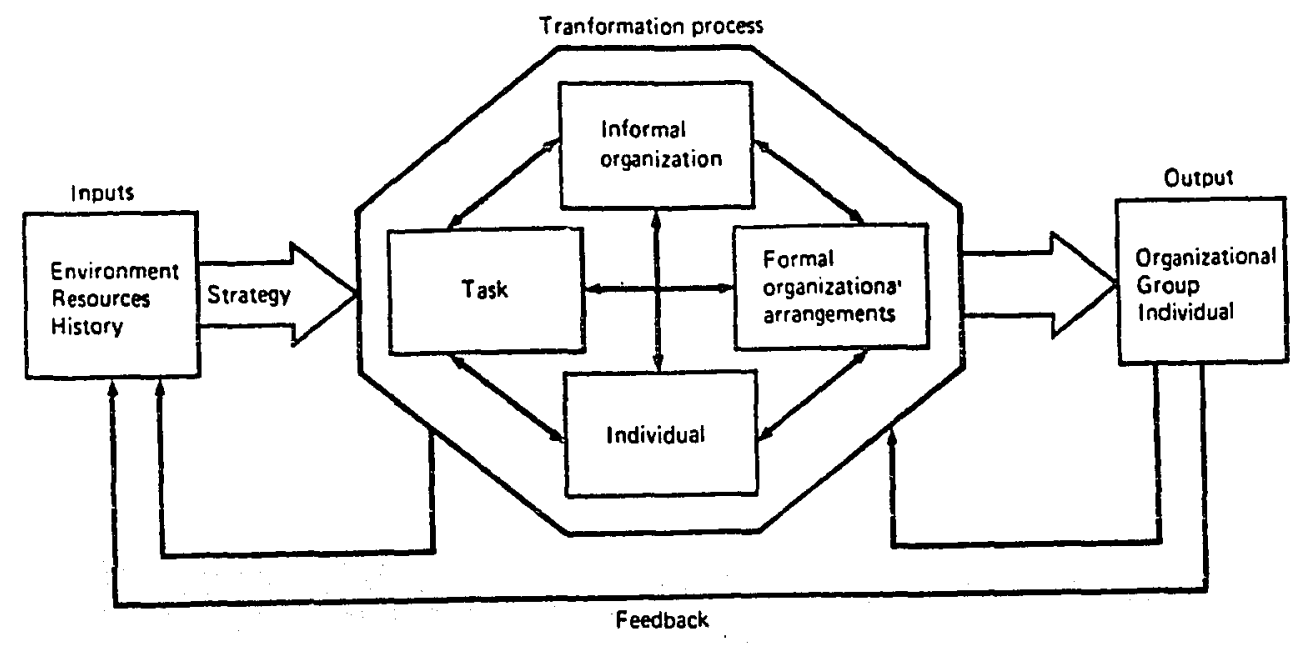

Figure 7. A systems model of organizational behavior (Nadler \& Tushman, 1980).

The study has three key foci: 1) the current knowledge founda- . tion of the organization that is reflected by employee educational background and organizational experience, 2) the extent that the knowledge is continually being improved, and 3) the extent that the organization sustains a positive development climate for its members. Secondarily, the study examines 1) current, as well as preferred, development methods, 2) reward preferences and their relationship to development, and 3 ) the influence of education background and length of service on development behavior. 
Methods

Data were collected through a random sample of 550 nonmanager engineers. Additional information was obtained from the Human Resource Information System (HRIS). The questionnaire consisted of individual background information, a modified version of the Work Description Questionnaire for Engineers (WDQE), and supplemental reward and development sections. Key work environment factors investigated were: 1) organization support, 2) management support, 3) peer support, 4) communication and involvement, 5) work assignments, and 6) overall climate. Responses were obtained from 320 nonmanager engineers. A chi-square analysis tested for differences among education and length of service groups.

\section{Findings}

The study is guided by five central questions. Each question is presented followed by the key findings related to the question.

Question 1. What is the current knowledge base of organizational members?

The examination of knowledge foundations suggested that an actual engineering population has not only different functional, knowledge discipline backgrounds, but also substantially different degrees of formal knowledge development. While $50 \%$ had bachelor degrees in engineering and $20 \%$ had advanced degrees, $30 \%$ reported no degree in engineering or engineering-related disciplines. Educational differences were present across all age, length of service and sex groups. Additionally, engineers differed significantly in their 
experience with the organization. While organizational experience ranged from 1 to 34 years, it averaged eight years with 46\% reporting fewer than 5 years experience with the organization. Fifty-four percent of the bachelor-degreed engineers and $65 \%$ of the advanced-degreed engineers reported five or fewer years of service with the organization.

Question 2. To what degree do members update their knowledge?

The data suggest that knowledge foundations are updated on a limited basis by degree education. Twenty-two percent of the respondents reported working on degrees. Those engineers with bachelor degrees and 5 or fewer years of service reported the highest percentage of degree development activity. Advanced degreed and career engineers $(11+$ LOS) reported the least amount of degree development activity. Since only one-fifth of the engineers were actively involved in degree programs, one can conclude that continuing education for engineers must come from non-degree-related development. This would be expected for engineers with advanced degrees and perhaps the majority of those with bachelor degrees.

Engineers reported educational development in non-degree related courses and seminars, independent reading, and networking. Engineers averaged one course per year, with more engineers taking internal courses than external ones. Advanced-degreed engineers reported the highest nonparticipation in internal courses and seminars. Nonparticipation in courses and seminars outside the company remained constant, independent of length of service and education. Significant to a discussion of knowledge obsolescence is the percentage of engineers 
who reported no course and seminar activity in the past two years $(20 \%)$. Even though reading is reported as the most prevalent and effective method currently used for development, the majority reported an average reading level of 0-2 hours weekly. Degreed engineers reported significantly more reading behavior than non-degreed engineers, while no dirferences occurred for length of service groups. Networking results show that the immediate work group serves as the primary basis for new information independent of education and length of service. Information flow from other parts of the company and from outside the company is increasingly restricted. In summary, the non-degree development pattern of engineers in this study is characterized by one course or seminar a year, 2-4 hours of independent reading per week and discussions within the work group.

Question 3. What methods do members prefer to update their knowl edge?

Engineers gave moderately high ratings to several development methods. The most effective methods were: 1) a challenging job, 2) reading, 3) earning an advanced degree, 4) taking courses and seminars, 5) working on interdisciplinary teams and 6) internal networking. Education groups differed significantly on two primary methods, reading and interdisciplinary teams. No significant differences occurred in selection of key development methods by length of service groups.

Question 4. To what degree do the organization's structure and processes (task, informal organization and formal organization) provide focus and incentive for individual development? 
Engineers indicated that time, cost, management and work demands were the primary barriers to development within the organization. Peers received the highest positive response (79\%) for support, followed by engineer involvement/communication and general climate at $66 \%$ and $62 \%$ respectively. Management and organizational support as well as work assignments were rated modestly with $56 \%, 54 \%, 47 \%$ positive responses. In general, the development climate was moderate.

While engineers identified challenging work as the most effective development method, only 53\% reported having jobs that stretched their knowledge. Even though $66 \%$ of the engineers indicated that managers do set performance goals, provide performance review for continuous improvement, and reward performance, just $40 \%$ reported being recognized and rewarded for development. Two-thirds of the engineers responded positively to communication and involvement in decision-making; yet, only $44 \%$ indicated that communication is open between organizational management and engineers. Additional inhibitors of the organization to development included lack of goal clarity, career guidance, rewards and recognition for development and performance, and opportunity for job rotation.

The reward climate and its relationship to development was explored more in depth. The rationale for examining the 1 inkage of individual values, behavior and rewards is supported by expectancy theory (Vroom, 1964) which hypothesizes that the motivation to engage in a particular activity will occur when an individual's expectancy perception is high, when the individual believes that effort will result in the desired performance, and when the performance is linked 
to a valued reward. Though engineering groups showed differences in preferred rewards, key rewards were equally valued by education and length of service groups. Primary rewards selected included salary and merit increases, achievement, advancement, recognition, and challenging work. Secondary rewards were self-initiative, supervisor relations, peer relations, job security and encouragement of ability. In the primary rewards, education groups showed significant differences for challenging work, while length of service groups did not. Also, career- and non-degreed engineers reported higher importance for job security than other education and length of service groups.

The majority of engineers reported opportunity for valued rewards independent of development, even though perceived opportunity for rewards did increase with development. Twenty-one percent reported a high opportunity for rewards independent of deveiopment with an additional $59 \%$ reporting a moderate opportunity for rewards independent of development. High opportunity for reward shifted from $21 \%$ if skills remained the same to $57 \%$ if skills were improved. Longer-service engineers reported less opportunity for recognition, advancement, and salary/merit increases even with improved skills than other length of service groups. Degreed engineers linked opportunity for challenging work with increased development more than non-degreed engineers.

Question 5. To what degree are the focus and support for development provided independent of members' current education background and experience within the organization? 
Nu11 hypotheses were tested examining differences for education and length of service groups for key areas of the study. They were:

1. Al1 education and LOS groups will report the same degree of current development behavior. (.05)

2. A11 education and LOS groups will report equivalent work climates. (.05)

3. All education and LOS groups will value the same rewards. (.05)

4. All education and LOS groups will report the same opportunity for valued rewards if technically current. (.05)

5. All education and LOS groups will value the same developmental activities. (.05)

Education groups exceeded the number of differences expected for development behavior, work climate, reward preference, and learning methods $(p>.05)$. However, the number of differences exceeding that expected were few. Therefore, all null hypotheses for education groups are accepted.

Length of service groups exceeded the number of differences expected for development behavior and opportunity for reward with improved skills $(p>.05)$. Again, the number of differences beyond that expected were few; thus, the null hypotheses for length of service groups are also accepted.

\section{Conclusions}

An essential assumption of this study is that knowledge development occurs within and is influenced by the task, i.e., the work to be 
done, as well as by the informal and formal structures of the organization. These are, in turn, influenced by members' needs and values. Given this dynamic context for knowledge development, the following conclusions are made:

1. Human resource development, to be effective and value-added for the organization, must be integrated with the ongoing strategic planning process to ensure development of goal clarity, optimization of development resources, and future availability of requisite, quality knowledge and skills.

2. Challenging work is critical to continuous development, since it is the primary focus of the individual organization contract, an effective development method, and a primary, intrinsic reward.

3. People in work organizations are a heterogeneous population showing differences in educational background, organization experience, education preferences and behavior, and reward preferences that in turn influence continuing education.

4. A stronger link between performance, reward and development systems would increase the incentives for individual development.

5. Increased integration of work and development could increase focus for and participation in development activities.

6. Hork climate influences educational development and should be systematically monitored by organizations to ensure support for development goals. 
7. Degree and non-degree as well as directed and non-directed Tearning opportunities are needed to meet the development preferences and needs of a heterogeneous population.

8. Human resource information should include a database of educational background and continuous development activities as well as key transferable skills and primary technologies of the organization to assist in determining present and future organizational capability.

\section{Importance of Study}

Human Resource Management

Individual development is a logical result of the human resource planning activity within an organization. Glueck (1982) defines human resource planning as a process by which management determines how the organization should move from its current human resource position to its desired position. Human resource goals must be consistent with organizational objectives, environmental conditions, and the attitudes and skills of employees. Thus, human resource planning works to achieve an optimal match between employee knowledge/skills and the work to be done.

This study supports the importance of strategic human resource planning for development to minimize the threat of knowledge obsolescence. Combatting knowledge obsolescence means not only identifying knowledge/skill requirements and shifts, targeting activities and programs to ensure a bank of needed skills, but also assessing and monitoring of policies and practices, work design, skill utilization, and 
work climate. Effective job design, performance and reward programs contribute strongly to long-term human resource development. These must operate in concert to provide a strong, positive development climate. Systematic monitoring and adjustments are important to ensure ongoing effectiveness.

The study suggests that managers consider the diversity of member needs and values when designing structures and processes to support development. For example, while extended schooling may support development for individuals in early careers, focused job-related nonschooling methods may be preferred by longer-service employees. The study also shows that members are motivated by different rewards. These preferred rewards, many of which are intrinsic to the work itself, need to be available for both performance and learning. Indeed, continuous learning may be an essential performance indicator of dynamic, changing organizations.

The study also has implications for hiring and integration of new employees. Organizations must set prehire expectations for continuous development as an essential element of the employment contract. New employees should not only be carefully selected to match present critical skill needs, but screened for their motivation for continuous improvement as well as for self-directed learning skills. Also, critical to hiring and employee socialization is an orientation to changing work roles and the understanding that work success will be less determined by continuous upward mobility, and more by varied, functional and crossfunctional career experiences. With dynamic job requirements and changing work roles, continuous development of new 
marketable and transferable skills may be the only assurance of career potential within and across a dynamic organization. The importance of extensive specialized experience may give way to generalized expertise as careers are governed by the ability to add-value and to contribute as opposed to tenure, longevity and fixed specialized career paths within organizations.

Human Resource Information Systems

Human resource information systems play a critical role in establishing databases necessary in assessing human resource performance and capability. This study suggests that such a database should include individual files for the following:

a. Educational background and specializations

b. Work experiences

c. Performance results

d. Reward patterns

e. Development behavior

(1) additional education (speciailizations)

(2) training including cross-functional development

Without such basic information, the organization is limited in assessing future capability, optimally matching current capability to near-term objectives, and targeting development for long-term objectives. Such a database also provides management opportunity to monitor the consistency of performance, development and reward systems. 
Educational Theory and Practice

Organizational development is as critical for modern educational institutions to become adaptive and responsive as for other organizations currently undergoing dramatic change. Effectiveness must include the ability of educational organizations to adapt to the environment, to set and to achieve goals, to maintain internal congruence, and to create and maintain motivational and value systems (Hoy \& Ferguson, 1985). Culbertson (1983) states that "successful instruction and goal attainment will miss the mark if the outcomes toward which instruction is directed are societally obsolescent" (p. 282). Thus, one chalienge for educational administrators is to assess the degree to which educational institutions pursue objectives related to the declining industrial society rather than the needs of the expanding information society.

This study suggests that today's adaptive, responsive organizations can combat knowledge obsolescence and sustain vitality through integration of reward, performance and deveiopment systems that are flexibly administered to accommodate individual differences and are systematically monitored to ensure effectiveness. The study contributes to educational administration by increasing the awareness of these critical elements related to knowledge obsolescence and continuous individual development.

On the other hand, the study raises questions about the viability of schools and universities without ongoing improvement and integration of human resource systems including selection, performance, development, and rewards. The study provides an integrated systems 
model for the study of organizational issues as well as an initial approach for examining knowledge obsolescence in an organization that could be applied to human resource management in eudcational organizations.

Such an approach is consistent with the product-accountability model and the techno-structural model of organizational development recommended by Schmuck and Miles (1971) for broader application and research in educational environments. The product-accountability model focuses on assessment of objectives and results that then are used to establish development goals. The techno-structural model involves examination of redesign, staffing patterns, student flow, and teaching structures. A review of the state of art in organizational development in schools (Fullan \& Miles, 1978) shows that the majority of organizational development efforts in schools focus on communication, problem solving and group functioning as opposed to comprehensive school improvement and accountability.

Secondly, the criticalness of lifelong learning, the learning to learn concept, as a goal of education has been recognized as essential for life in modern society (Cropley, 1979; Lengrand, 1979; Gelpi, 1979; Lewis, 1983). Thus, the issue raised by knowledge obsolescence extends beyond what is relevant curriculum to whether the methods of schooling enable individuals to become lifelong leaners. Critical are the processes that strengthens the individual's ability to take charge of life situations, to manage continuous change, to create a "steadystate" When change is rampant and to remain effective even when the environment is uncertain. 
Further, as the world moves to a knowledge-based competitive strategy, thinking and critical analysis become necessary for individual survival where innovation emerges from difference, disagreement, confrontation, heterogeneity and diversity of thought and opinion. A UNESCO report (Charters, et al., 1972) on the schools influence of students' desire to learn and to continue learning states that a major goal of education is to produce learners who assume responsibility for initiating and directing their own education. It suggests that clues about motivation for continued learning could be ascertained from studying adult participation and learning activities that then could be translated to the school setting. The UNESCO report challenges the thought that education is considered the same as schooling saying that "the process of learning has become encapsulated in institutions," with the assumption that education begins with schools, occurs in a school isolated from the community and ends with schooling. However, the report notes that these assumptions are less appropriate today as new information about the formative years before schooling emerges and the fallacy of schooling as preparation for life is substantiated in real time with rapid changes in society.

Consistent with the thinking of the UNESCO report, one could argue that educational administration and research should include an investigation of the degree to which adults show patterns of continued learning, what those patterns are, and the degree to which adults remain dependent on "schooling" as a primary means of development. If educational institutions, as a part of their central mission, are to prepare youth to be lifelong learners, it appears that more information is needed on the persisting problem of knowledge obsolescence. 
For lifelong learning to be optimized it has been suggested (Cropley, 1979) that more emphasis be given to the following:

1. Recognition of a variety of iearning styles.

2. Increased role of learner in the learning process including initiative and control rather than dependence on the teacher.

3. Greater recognition of the value of informal learning as complementary to traditional classroom instruction.

4. Greater emphasis on flexible and adaptive structure, content, and operation of learning services.

5. Greater co-ordinating among various educational agencies to which the individual is exposed.

6. Closer linkage between schools and community.

7. Greater conviction that systematic learning is a permanent need during the whole of a person's iife as a result of continuous new developments in technology, work, human relationships, and institutions.

8. Increased understanding that "all educational trends and practices....are not isolated, independent and without relevance to each other, but correspond in each case to one aspect of the overall innovative pattern imposed by modern conditions on the 'one' educative and learning process..." [xi].

Thus, lifelong learning is facilitated by appropriate support aimed at increasing an individual's interest and capacity in lifelong learning that should be supported by educational practices in 
schools. Finally, it is suggested that the learning in schools and universities should be closely linked with learning in nonschool settings (Cropley, 1979), that the analysis of the production sector is therefore central to a discussion of lifelong education (Gelpi, 1979), as changes in the nature of work are key to the transformation of education, and that the evaluation of schools must include their contribution to adult learning patterns. Thus, this study in examining learning in a nonschool setting seeks to provide insight into the contribution that educational institutions could make as infrastructure to lifelong learning behavior patterns that provide the skills, attitudes, and motives necessary for self-directed learning.

Thirdly, with an increased understanding of current work environments, educational leaders can better clarify their roles in education-industrial partnerships that are currently being formed as a partial response to the problem of knowledge obsolescence and scarce resources for development within both educational and industrial sectors.

\section{Electronics Industry}

The electronics industry employs engineers whose knowledge and skills are markedly affected not only by rapidly changing technologies, but by shifts in market demands and opportunities. In turn, electronic companies for innovation, design, and development of products and services are dependent on engineers with critical technical ski11s. Concern about employment of engineers has less to do with the number of engineers available in the marketplace and increasingly more 
to do with engineers who have appropriate knowledge and experience in emerging technoiogies. The volatile nature of technology and markets in the electronics industry suggests that these companies could benefit from understanding the issues and challenges of managing knowledge obsolescence in engineers in particular, and in their dynamic work force in general. Human resource planning and development systems that are tightly linked to strategic and operational plans appear imperative to the management of engineers in the electronics industry. Employment forecasting, human resource inventorying, and development form the core of ongoing activities that may ensure availability of needed, quality skills. Since development is a precursor to effective application, a proactive approach could minimize knowledge obsolescence.

The issues and challenges that have been raised by this study include:

1. The differences among engineers that influence development and performance behavior.

2. The integration of strategic business planning with strategic employee planning, including availability, skill mix, development and motivation issues.

3. The influence of the work environment on development and performance behavior.

4. The needed bal ance between near-term performance and longterm capability. 


\section{Recommendations for Further Research}

The present exploratory study of knowledge obsolescence in a dynamic organizational context raises more questions, perhaps, than it answers for organizational leaders whose organizations survive solely or in part by human-intensive, knowledge technology. Thus, continued research into the management of knowledge obsolescence, particularly through additional case studies of organizations, could increase both awareness and understanding of the dynamics of knowledge obsolescence in organizations. In addition to organizational case studies, the following research areas are recommended:

1. A study of manager attitudes toward development of engineers as well as their current methods and incentives, could providecritical insights to conflicting organizational goals.

2. Since challenging work has consistently emerged as central $t$ development, research defining the elements of challenging work for engineers could add value to work design research a we11 as methods to knowledge development.

3. A study of the purpose, values, and culture of the organization in relation to employee development could provide insights into barriers that inhibit development within the organization.

4. Continued investigation into the influence of educational background, length of service, as well as other individual variables under the influence of the organization could increase the understanding of relevant individual variables 
in a human resource context where changing demographics, values, and needs and preferences influence both periormance and development.

5. Similar studies could be conducted with other job families whose work is knowledge-driven, since the numbers of knowledge workers are increasing and therefore will have a greater impact on the effectiveness of more organizations. 


\section{BIBLIOGRAPHY}

Adams, J.A. (Ed.). (1984). EEs on lifelong learning. IEEE Spectrum, 21, $92-98$.

Allen, W.C. (1985). A different drummer: Education for engineers in industry. In L.P. Grayson \& J.M. Biedenbach (Eds.), Proceedings of the 1985 College Industry Education Conference (pp. 202205). Washington, DC: American Society for Engineering Education.

Alpander, G.G. (1982). Human resources management planning. New York: American Management Association.

Argyris, C. (1957). Personality and organization: The conflict between the system and the individual. New York: Harper and Brothers.

Arvey, R.R., \& Neel, C.W. (1976). Motivation and obsolescence in engineers. Industrial Gerontology, 3, 113-120.

Avciding Obsolescence: Guidelines for engineers and managers. (1978). Design News, 34, 144-146.

Bailyn, L. (1980). Living with technology: Issues at mid-career. Cambridge MA: The MIT Press.

Bailyn, L. (1982). Career fulfillment strategies for mature engineers. Computer Design, 21, 73-74.

Bailyn, L. (1982). Resolving contradictions in technical careers or what if I like being an engineer? Technology Review, 85, 40-47.

Baldridge, J.V., \& Deal. T. (Eds.). (1983). The dynamics of organi zational change in education. Berkeley, CA: McCutchan.

Barrett, G.V. (1970). Combatting obsolescence using perceived discrepancies in job expectations of research managers and scientists. New York: Rochester University, Management Research Center. (ERIC Document Reproduction Service No. ED 047 250)

Benton, J.B. (1973). Managing the organizational decision process. Lexington, MA: D.C. Heath.

Best, F. (1984). Technology and the changing world of work. The Futurist, 18, 61-66. 
Blood, J.W. (Ed.). (1961). Optimum use of engineering talent. Cambridge, MA: Riverside Press.

Blumberg, M., \& Pringle, C.D. (1982). The missing opportunity in organizational research: Some implications for a theory of work performance. Academy of Management Review, $7,560-569$.

Braddock, D. (1983). Engineers--Higher than average risk of obsolescence. Occupational Outlook Quarterly, 27, 9-11.

Bridenbaugh, P.R. (1985). Design and development of an education and training program for Alcoa Laboratories. In L.P. Grayson \& J.M. Biedenback (Eds.), Proceedings of the 1985 College Industry Education Conference (pp. 152-155). Washington DC: American Society for Engineering Education.

Brookfield, S. (1984). Self-directed learning: A critical paradigm. Adult Education Quarterly, 35, 59-71.

Burack, E.H. (1972). Meeting the threat of managerial obsolescence. Cal ifornia Management Review, 15, 83-90.

Burack, E.H., \& Pati, G.C. (1970). Technology and managerial obsolescence. Michigan State University Business Topics, 2, 49-56.

Burack, E.H., \& Smith, R. D. (1982). Personnel management: A human resource system approach. New York: John Wiley \& Son.

Burke, R.J. (1969). Effects of aging on engineers' satisfaction and mental health: Skill obsolescence. Academy of Management Journal, 12, 467-486.

Burke, W.W. (Ed.). (1978). The cutting edge: Current theory and practice in organization development. La JoTTa, CA: University Associates.

Burnet, G. (1979). Engineering education: Colleges can't do it a11. Machine Design, 51, 138-45.

Charters, A. N., Blakely, R.J., Lally, J.R. Lay, M., Porter, L., \& Copeland, H. (1972). The influence of schools on continuing education in the United States of America. In The school and continuing education: Four studies (pp. 100-168). Paris: UNESCO.

Counteracting obsolescence in employees and organizations. (1979). Training, 16, 80-82.

Criss, J.C. (1973). The out-of-date employee in an up-to-date world. Journal of Systems Management, 24, 37-41. 
Cropley, A.J., (Ed.). (1979). Lifelong education: A stocktaking. Hamburg, Germany: UNESCO Institute for Education.

Culbertson, J.A. (1983). Leadership horizons in education. Educational Administration Quarterly, 19, 273-296.

Dalton, G.H., \& Thompson, P.H. (1971). Accelerating obsolescence of older engineers. Harvard Business Review, 49, 57-66.

Dalton, G.W., Thompson, P.H., \& Price, R.L. (1977). The four stages of professional careers--A new look at performance by professionals. Organizational Dynamics, 6, 19-42.

Danielson, L. E. (1960). Characteristics of engineers and scientists. Ann Arbor, MI: University of Michigan.

Davis, L.E. (1977). Evolving alternative organization designs: Their sociotechnical bases. Human Relations, 30, 261-273.

Diebold, J. (1984). Making the future work: Unleashing our powers of innovation for the decades ahead. New York: Simon and Schuster.

DiMarco, N. (1980). Worker motivation: Age difference in engineers. ISA Transactions, 19, 37-42.

Dubin, S.S. (1972). Obsolescence or 1ifelong education: A choice for the professional. American Psychologist, 27, 486.

Dubin, S.S. (1977). A learning model for updating oider tecinnicai and professional persons. ASEE Continuing Engineering Studies Division Newsletter, $7,1-T$.

Dubin, S.S. (1981). Appiying motivational knowhow encourages engineers to 1earn. EDN Design Management, 26, 165-67.

Dubin, S.S. (1981). Managers can make it easy for engineers to keep up to date. EDN Design Management, 26, 125-26.

Dubin, S.S., \& Cohen, D.M. (1970). Motivation to update from a systems approach. Journal of Engineering Education, 60, 366-368.

Dubin, S.S., Shelton, H., \& McConnell, J. (Eds). (1974). Maintaining professional and technical competence of the older engineer-Engineering and psychological aspects. Washington, oc: American Society for Engineering Education.

Dyer, L. (1984). Human resource planning at IBM, Human Resource Planning, 2, 111-125.

Emery, F.E., \& Trist, E. (1965). The causal texture of organizational environments. Human Relations, 18, 21-31. 
Farr, J.L., Dubin, S.S., Enscore, E.G., Kozlowski, S. W. J., \& Cleveland, J.N. (1980). Relationships among individual motivation, work environment, and updating in engineers. Final Report. University Park, PA: Pennsylvania State University. (ERIC Document Reproduction Service No. ED 195 439)

Farr, J.L., Emory, E., Steiner, D.D., \& Kozlowski, S.W.J. (1984). Factors that influence the technical updating of engineers. University Park, PA: Pennsylvania State University.

Farr, J.L., Enscore, E.E., Dubin, S.S., Cleveland, J.N., \& Kozlowski, S.W.J. (1980). Behavior anchored scales--A method for identifying continuing education needs of engineers. Final Report. University Park, PA: Pennsylvania State University. (ERIC Reproduction Service Document No. ED 195 438)

Ferdinand, T.N. (1966). On the obsolescence of scientists and engineers. American Scientist, 54, 45-56.

Fitch, D. (1982). Increasing productivity in the microcomputer age. Reading, MA:, Addison-hestey.

Flannery, W.T. (1983). Performance appraisal defines career expectations. EDN Design Management, 28, 227-229.

Fluke, J.M. (1981). Training and retaining EEs. EDN Design Management, 26, 254-56.

Frasher, R.D. (1969). An appraisal of the status and future of the continuing education (non-credit for engineers in the United States). Columbus, OH: Ohio State University. (ERIC Document Reproduction Service No. ED 032 466)

French, H. L., \& Be11, C.H. (1984). Organization development: Behavioral science interventions for organization improvement. Englewood Cliffs, NJ: Prentice-Hall.

Frohman, A.L. (1974). Critical functions for an innovative R\&D organization. Business Quarterly, 39, 72-81.

Fryer, M.A., \& Zimmerer, T.W. (1975). The work environment: Key to greater productivity. The Personnel Administrator, 20, 38-42.

Fullan, M., \& Miles, M. (1978), OD in schools: The state of the art. In W.W. Burke (Ed.), The cutting edge: Current theory and practice in organization development (pp. 149-175). La Jolla, CA: University Associates.

Gailbraith, J. (1973). Designing complex organizations. Reading, MA: Addi son Hesley. 
Gautshi, T.F. (1978). Continuing education is not enough. Design News, 34, 137-138.

Geipi, E. (1979). Lifelong education: Suggestions for an evaluation of experiences. In A.J. Cropley (Ed.), Lifelong education: A stocktaking (pp. 50-62). Hamburg, Germany: UNESCO Institute for Education.

Gibson, J.L., Ivancevich, J.M., \& Donnelly, J.H. (1982). Organizations: Behavior, structure, processes. Dallas, TX: Business Publications.

Glueck, W.F. (1982). Personnel: A diagnostic approach. P1ano, TX: Business Publications.

Guest, R.H., Hersey, P., \& Blanchard, K.H. (1977). Organizational change through effective leadership. Englewood Cliffs, NJ: Prentice-Hall.

Gregory, G. (1984). Why Japan's engineers 1ead. Management Today, 50-55.

Hackman, J.R. (1983). Designing work for individuals and for groups. In J.R. Hackman, E.E. Lawler \& L.W. Porter (Eds.), Perspectives on behavior in organizations (pp. 242-257). New York: McGrawHill.

Hackman, J.R., \& 01 dham, G. (1975). A new strategy for job enrichment. California Management Review, 17, 57-71.

Hal1, D.T., \& Mansfield, R. (1975). Relationships of age and seniority with career variables of engineers/scientists. Journal of Applied Psychology, 60, 201-210.

Heneman, H.G., \& Schwab, D.P. (Eds.). (1982). Perspectives on personnel/human resources management. Homewood, IL: Richard D. Irwin.

Hersey, P., \& B1 anchard, K.H. (1977). Management of organizational behavior: Utilizing human resources. Englewood Cliffs, NJ: Prentice-HalT.

Herzberg, F. (1979). Herzberg on motivation for the '80s. Industry Week, 201, 59-63.

Hi 11, J.E., \& Kerber, A. (1967). Models, methods, and analytical procedures in educational research. Detroit, MI: Wayne State University.

Hubbard, P.H., \& Storm, K. (1984). AEA status report on engineering and technical education. Palo Alto, CA: American Electronics Association. 
Horgan, N.J. (1971). An MBO approach to prevent technical obsolescence. Personnel Journal, 50, 687-693.

Hoy, W.K., \& Ferguson, J. (1985). A theoretical framework and exploration of organizational effectiveness of schoois. Educational Administration Quarterly, 21, 117-134.

Ivancevich, J.M., Szilagy, A.D., \& Wallace, M.J. (1977). Organizational behavior and performance. Santa Monica, CA: Goodyear.

Jayaram, G.K. (1976). Open systems planning. In W.G. Bennis, K.D. Benne, R. Chin \& K. Corey (Eds.), The planning of change (pp. 275-283). New York: Holt, Rinehart andwinston.

Jewkes, G., Dalton, G. , \& Thompson, P. (1979). How to stifle a technical organization in ten easy steps. Research Management, 22, 12-16.

Jones, A.N., \& Cooper, C.L. (1980). Combatting managerial obsolescence. Deddington, Oxford: PhitTip Allan.

Kanter, R.M. (1983). The change masters: Innovation and entrepreneurship in the American corporation. New York: Simon and Schuster.

Kaufman, H.G. (1972). Relations of ability and interest to currency of professional knowledge among engineers. Journal of Applied Psychology, 56, 495-499.

Kaufman, H.G. (1973). Individual differences, early work challenge, and participation in continuing education. Journal of Applied Psychology, 60, 405-408.

Kaufman, H.G. (1974). Obsolescence and professional career development. New York: AMACOM.

Kaufman, H.G. (Ed.). (1975). Career management: A guide to combating obsolescence. New York: IEEE Press.

Kaufman, H.G. (1978). Continuing education and job performance: A 1ongitudinal study. Journal of Applied Psychology, 63, 248-251.

Kaufman, H.G. (1979). Technical obsolescence: Work and organizations are the key. Engineering Education, 69, 26-30.

Kemper, J.D. (1975). The engineer and his profession (Second edition). New York: Holt, Rinehart andWinston.

Kopelman, R.E. (1977). Psychological stages of careers in engineering: An expectancy theory taxonomy. Journal of Vocational Behavior, 10, 270-286. 
Krejcie, R.V., \& Morgan, D.W. (1970). Determining sample size for research activities. Educational and Psychological Measurement, 30, $607-610$.

Landis, F. (1969). Continuing engineering education: Who really needs it: What is the market for continuing education? New York: New York University, College of Engineering. (ERIC Document Reproduction Service No. ED 041 230)

Lawler, E.E. (1973). Motivation in work organizations. Monterey, CA: Brooks/Cole.

Lawler, E.E. (1983). Strategies for improving the quality of work iife. American Psychologist, 37, 486-493.

Lawler, E.E. (1984). Increasing worker involvement to enhance organizational effectiveness. In P. S. Goodman (Ed.), Change in organizations: New perspectives on theory, research, and practice (pp. 280-315). San Francisco: Jossey-Bass.

Lengrand, P. (1975). An introduction to lifelong education. Paris: UNESCO Press.

Lengrand, P. (1979). Prospects of 1 ifelong education. In A.J. Cropley (Ed.), Lifelong education: A stocktaking (pp. 28-35). Hamburg, Germany: UNESCO Institute for Education.

Levering, R., Moskowitz, M., \& Katz, M. (1985). The 100 best companies to work for in America. New York: PIume Printing.

Lewis, A.J. (1983). Education for the 21st century. Educational Leadership, 41, 9-10.

Likert, R. (1961). New patterns of management. New York: MCGraw-Hill.

Lippitt, G.L. (1982). Organization renewal: A holistic approach to organization development. Englewood Cliffs, NJ: Prentice-HaT1.

MacGregor Burns, J. (1978). Leadership. New York: Harper \& Row.

Macy, B.A. (1981). Productivity and QWL: A dual imperative. The Texas Center for Productivity and Quality of Work Life. Lubbock, TX: Texas Tech University.

Mack, D.R. (1986). General Electric's continuing education program. In L.P. Grayson \& J.M. Biedenback (Eds.), Proceedings of the 1986 College Industry Education Conference Proceedings (pp. 89-92). Hashington, DC: American Society for Engineering Education.

Mali, P. (1969). Measurement of obsolescence in engineering practitioners. Manage, 21, 48-52. 
Margulies, N., \& Raia, A.P. (1967). Scientists, engineers, and technical obsolescence. California Management Review, 10, 43-48.

Margulies,, N. \& Raia, A.P. (1978). Conceptual foundations of organizational development. New York: McGraw-Hill.

Margulies, N., \& Wallace, J. (1973). Organizational change: techniques and applications. Glenview, IL: Scott, Foresman.

Maslow, A. H. (1954). Motivation and personality. New York: Harper \& Row.

Matti11, J.I. (1983). High stakes in lifelong education. Technology Review, 86, 81.

McCarrey, M.H., \& Edwards, S.A. (1973). Organization climate conditions for effective research scientist role performance. Organization Behavior and Human Performance, 9, 439-459.

McGregor, D. (1966). Leadership and motivation. Cambridge, MA: The MIT Press.

McKelvey, B., \& Sekaran, U. (1977). Towards a career-based theory of job involvement: A study of scientists and engineers. Administrative Science Quarterly, 22, 281-305.

Mennis, D. (1981). Breaking down the data on EEs and their careers. Electron Design, 29, 251-261.

Miles, R.E. (1975). Theories of management: Implications for organizational behavior and development. New York: McGrawHitT.

Miles, R.E., \& Rosenberg, H.R. (1982). The human resources approach to management: Second-generation issues. Organizational Dynamics, 10, 26-41.

Miller, D.B. (1977a). How to improve the performance and productivity of the knowledge worker. Organizational Dynamics, 5, 62-80.

Miller, D.B. (1977b). Personal Vitaility. Reading, Ma: AddisonWesley.

Miller, D.B. (1979). Counteracting obsolescence in employees and organizations. Professional Engineer, 49, 29-31.

Miller, J.E. (1976). Eliminate your obsolescence. Journal of System Management, 27, 34-36.

Mintzberg, H. (1973). The nature of managerial work. New York: Harper \& Row. 
Mintzberg, H. (1979). The structuring of organizations. Englewood Cliffs, Nu: Prentice-HalT.

Misshauk, M.J. (1970). importance of environmental factors in scientists-engineers. Personnel Journal, 49, 319-323.

Morris, A.J. (1978). Continuing education for engineers and on the job performance: The compensation connection. Professional Engineer, 48, 22-25.

Morris, A.J. (1980). Continuing education: Its returin on investment. Chemical Technology, 10, 470-73.

Moye A. (1986, February). Continuing education at Hewlett-Packard. Paper presented at the meeting of the American Society for Engineering Education, New Orleans, LA.

Murdick, R.G. (1964). Business research: Concept and practice. Scranton, PA: International Textbook.

Murphy, M.J., \& Werne, R.H. (1985). Renaissance of a continuing education program. In L.P. Grayson \& J.M. Biedenback (Eds.), Proceedings of the 1986 College Industry Education Conference (pp. 156-158). Washington, DC: American Society for Engineering Education.

Nadler, D.A., Hackman, J.R., \& Lawler, E.E. (1979). Managing organizational behavior. Boston: Little, Brown.

Nadler, D.A., \& Lawler, E.E. (1983). Motivation: A diagnostic approach. In J.R. Hackman, E.E. Lawler \& L.W. Porter (Eds.), Perspectives on behavior in organizations (pp. 67-73). New York: McGraw-Hill.

Nadler, D.A., \& Tushman, M.L., (1980). A congruence model for

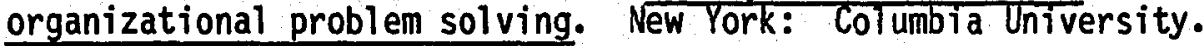

Orth, C.D. (1975). Motivation and career development of engineers. Atlantic Economic Review, 25, 51-54.

Padilla, J.J. (1985). Meeting emerging professional needs. In L.P Grayson \& J.M. Biedenback (Eds.), Proceedings of the 1986 College Industry Education Conference (pp. 59-69). Washington, DC: American Society for Engineering Education.

Pascarel1a, P. (1983). Can management breakout of its box? Industry Week, 219, 53-55. 
Pasmore, W.A. (1982). Overcoming the roadblocks in work-restructuring efforts. Organizational Dynamics, 10, 54-67.

Patton, C. (1979). The challenge of beeping current. IEEE Spectrum, $16,53-59$.

Peake, H.J. (1979). Combating engineer obsolescence. Machine Design, 51, 223-24.

Pelz, D.C., \& Andrews, F.M. (1976). Scientists in organizations: Productive climate for research and development Thevised edition). Ann Arbor, MI: The University of Michigan.

Peters, T.J., \& Waterman, Jr., R.H. (1982). In search of excellence: Lessons from America's best-run companies. New York: Warner Books.

Price, R.L., Thompson, P.H., \& Dalton, G.H. (1975). Longitudinal study of technological obsolescence. Research Management, 18, 22-28.

Raitt, J. (1982). Retrain to retain: A prescription for the 1980s. Training and Development Journal, 36, 48-52.

Raudsepp, E. (1983). The ideal engineer. Machine Design, 55, 71-75.

Raudsepp, E., \& Yeager, J.C. (1983). How much freedom for engineers? Machine Design, 55, 67-70.

Ritti, R.R. (1971). The engineer in the industrial corporation. New York: Columbia University Press.

Robbins, S.P. (1983). Organizational behavior: Concepts, controversies, and applications. Englewood Cliffs, NJ: PrenticeHalT.

Rosow, J.M. (1981). Quality of work life issues for the 1980 s. Training and Development Journal, 35, 33-52.

Rothfeder, J. (1981). Job satisfaction overrides concern about low wages. Electron Design, 29, 351-57.

Sackett, W.T. (1985). Engineering obsolescence and continuing education at Honeywell. In L.P. Grayson \& J.M. Biedenback (Eds.), Proceedings of the 1986 College Industry Education Conference (pp. 159-162). Washington, DC: American Society for Engineering Education.

Schmuck, R.A., \& Miles, M.B. (1971). Organization development in schools. Palo Alto, CA: National Press Books.

Schwartz, H., \& Davis, S.M. (1981). Matching corporate cul ture and business strategy. Organizational Dynamics, 10, 30-48. 
Scott, W.R. (1981). Organizations. Englewood Cliffs, NJ: Prentice-Hall.

Seifert, W.W. (1964). The prevention and cure of obsolescence in scientific and technical personnel. Research Management, 7, 143-149.

Shafritz, J.M., \& Whitbeck, P.H. (1978). Classics of organization theory. Oak Park, IL: Moore.

Shearer, R.L. \& Steger, J.A. (1975). Manpower obsolescence--new definition and emperical investigation of personal variables. Academy of Management Journal, 18, 263-275.

Snyder, D.P. (1984). The strategic context of management in America 1985 to 1995. Bethesda, MD: Snyder Family Enterprise.

Soltis, L.A. \& Ebisch, R. (1979). Making continuing education pay off. Machine Design, 51, 100-104.

Spear, G.E. \& Mocker, D.W. (1984). The organizing circumstance: Environmental determinants in self-directed learning. Adult Education Quarterly, 35, 1-10.

Strauss, G., Miles, R.E., Snow, C.C., \& Tannenbaum, A.S. (1981). Organizational behavior: An overview. In F. Luthans \& K.R. Thompson (Eds.), Contemporary readings in organizational behavior (pp. 38-46). New York: McGraw-Hill.

Tannenbaum, R., \& Davis, S.A. (1969). Values, man and organizations. Sloan Management Review, 10, 68-85.

Thompson, P.H. \& Dalton, G.W. (1976). Are R\&D organizations obsolete? Harvard Business Review, 54, 105-116.

Toffler, A. (1985). The adaptive corporation. New York: McGrawHi 11.

Tough, A. (1971). The adult's learning projects: A fresh approach to theory and practice in adult Tearning. Toronto, Ontario: The Ontario Institute for Studies in Education.

Tushman, M.L., \& Moore, W.L. (1982). Readings in the management of innovation. Boston: Pitman.

Vroom, V.H. (1964). Work and motivation. New York: John Wiley \& Sons. 
Walton, R.E. (1979). Do supervisors thrive in participative work systems? Organizational Dynamics, $7,25-37$.

Walton, R.E. (1980). Quality of work life activities: A research agenda. Professional Psychology, 11, 484-493.

Walton, R.E. (1984). From control to commitment: Transforming work force management in the United States. Prepared for The Harvard Business School's 75th Anniversary Colloquium on Technology and Productivity.

Warwick, D.P., \& Lininger, C.A. (1975). The sample survey: Theory and practice. New York: McGraw-HiTा.

Wehrenberg, S.S. (1983). Training megatrends, Personnel Journal, 62, 279-280.

Weiner, Y. (1982). Comnitment in organizations: A normative view. Academy of Management Review, 7, 418-428.

Westcott, J.W. (1976). Employee obsolescence--A shared responsibility. Labor Gazette, 76, 241-243.

Yankelovich, D. \& Lefkowitz, B. (1982). Work and American expectations. Phi Kappa Phi, 62, 3-5.

Zelikoff, S.B. (1969). On the obsolescence and retraining of engineering personnel: A quantification of the problem and some recommendations. Training Development Journal, 5, 3-14.

Zimmerman, M.D. (1980). In what stage is your career? Machine Design, 52, 66-70.

Zukowski, R.W. (1985). Overcoming obstacies in continuing education programs. Utica, NY: General Electric. 
APPENDIX A 
Background Information

1. Group: COMM ISG CORP PORT DAG EMCO ARL IDG INTL

2. Number of years in Company:

3. Sex: $M$ F 4. Age

5. Engineering Education:
No Degree
- Bachelor's (first)
- Bachelor's (second)
- Master's
Doctorate

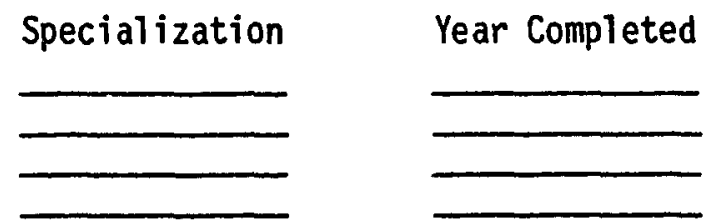

6. Are you currently working on a degree? Yes Specialization

7. Do you currently have a written plan established with your supervisor? Yes No

8. How many technical courses/seminars have you taken during the last 2 years not related to a degree program?
a. Inside Company
b. Outside Company

9. How many hours, on the average, do you spend reading technical journals and textbooks each week?

10. How many hours, on an average, do you spend discussing technical issues with other engineers each week? In your work group/project team.

- Dutside you work group but inside Company. Outside Company.

11. List in order the 3 most effective ways that you use to gain new technical information. 1. 3.

12. List in order of priority the barriers (if any) within the Company that keep you from getting the information or resources you need to improve your technical knowledge/skills. 1. 2. 3.

13. How would you describe your motivation for learning new technical information?

\begin{tabular}{|c|c|c|c|c|c|}
\hline $\begin{array}{l}1 \\
\text { very } \\
\text { low }\end{array}$ & $\begin{array}{c}2 \\
10 \mathrm{~W}\end{array}$ & $\begin{array}{c}3 \\
\text { moderately } \\
\text { low }\end{array}$ & $\stackrel{4}{\text { moderate }}$ & $\begin{array}{c}5 \\
\text { moderately } \\
\text { high }\end{array}$ & $\stackrel{6}{\text { high }}$ \\
\hline
\end{tabular}


14. How important is learning new technical information to your present job?

\begin{tabular}{|c|c|c|}
\hline $\begin{array}{l}1 \\
\text { not } \\
\text { important }\end{array}$ & 3 & $\begin{array}{c}4 \\
\text { moderate } \\
\text { important }\end{array}$ \\
\hline
\end{tabular}

15. How important is Tearning new technical information to your career development?

\begin{tabular}{|c|c|c|}
\hline $\begin{array}{l}1 \\
\text { not } \\
\text { important }\end{array}$ & 3 & $\begin{array}{c}4 \\
\text { moderate } \\
\text { important }\end{array}$ \\
\hline
\end{tabular}

A. Work Description Questionnaire for Engineers

The following statements are concerned with the nature of work assignments, the actions and attitudes of peers and supervisors, and the policies and characteristics of a company. We are interested in how you think that each of these statements describes your job, company, supervisor, or peers. Use the scale below to indicate your judgment about each statement. Write the number indicating your judgment in the space to the left of each statement. Please do not omit any statements.

$\begin{array}{ccccccc}1 & 2 & 3 & 4 & 5 & 6 & 7 \\ \text { strongly } & \text { disagree } & \begin{array}{c}3 \\ \text { disagree }\end{array} & \begin{array}{c}\text { disagree } \\ \text { disately }\end{array} & \text { no opinion } & \begin{array}{c}5 \\ \text { moderately agree } \\ \text { strongly } \\ \text { agree }\end{array}\end{array}$

1. My supervisor involves the engineers in establishing performance goals by which they are evaluated.

2. Fellow engineers discourage attempts to remain technically current.

3. Work assignments include state-of-the art technology and advanced instrumentation.

4. All engineering time must be charged to project budgets with no allowance for general technical updating.

5. My supervisor encourages engineers to present papers at technical meetings.

6. My supervisor holds periodic staff meetings to discuss technical problems and developments.

7. The company has a performance system that ties financial gain to technical competence.

8. The company is concerned with the professiona growth of its engineers.

9. Peers are willing to act as sounding boards for new ideas.

10. Engineers view the company as an innovator.

11. Engineers lack the authority to make technical decisions about a project.

12. The company provides its engineers with current technical equipment and facilities. 


$\begin{array}{ccccccc}1 & 2 & 3 & 4 & 5 & 6 & 7 \\ \text { strongly } & \text { disagree } & \text { moderately } \\ \text { disagree } & & \text { disagree } & \text { no opinion } & \begin{array}{c}\text { moderately } \\ \text { agree }\end{array} & \begin{array}{c}\text { strongly } \\ \text { agree }\end{array}\end{array}$

13. The company is involved in technically stagnant fields.

14. My supervisor is technically up-to-date and abreast of recent technical developments.

15. Personal creativity and growth are stifled by the company.

16. Engineers are often assigned to non-technical tasks.

17. The company provides career counseling for the engineer.

18. My supervisor matches the engineer's need for professional development with opportunities to attend courses and technical meetings.

19. Engineers are not aiways hired for engineering jobs.

20. There is a clear statement of the company's technological goals available to all engineers.

21. Peers often react negatively to new technical ideas.

22. My supervisor encourages the reading of technical journals and trade magazines during working hours.

23. Job assignments are challenges that stretch the engineer's technical knowledge to the limit.

24. Engineers participate in technical decisions relevant to their assignments.

25. My job allows some free time to explore new, advanced ideas.

26. The company attempts to be better technically than its competition.

27. Peers are able to provide reliable information about current technical developments.

28. The company recognizes the technical contribution of its engineers.

29. My supervisor elicits ideas from engineers about technical problems.

30. My supervisor provides career counseling for the engineers.

- 31. The company provides financiai suppori for attending professional meetings.

32. Engineers have a sense of personal involvement in the company's future.

33. My supervisor restricts the participation of the engineers in professional activities to a minimum.

34. Rewards are given to those engineers with technical competence.

35. Innovation is enthusiastically received by the company.

36. Information exchange is restricted by excessive compettition among the engineers.

37. My supervisor's performance reviews point out the engineers' strengths and weaknesses and offer suggestions for improvement.

38. The company stresses high professional standards

39. There are open 1 ines of communication between the engineering staff and company management. 


$\begin{array}{ccccccc}1 & 2 & 3 & 4 & 5 & 6 & 7 \\ \begin{array}{l}\text { strongly } \\ \text { disagree }\end{array} & \text { disagree } & \begin{array}{c}\text { moderately } \\ \text { disagree }\end{array} & \text { no opinion } & \begin{array}{c}5 \\ \text { moderately agree } \\ \text { agree }\end{array} & \begin{array}{c}\text { strongly } \\ \text { agree }\end{array}\end{array}$

40. The company's concern for the protection of proprietary information restricts interaction with other engineers.

41. My supervisor provides understanding of the total project by sharing information and encouraging communication among the engineers.

42. Peers usually draw attention to useful journal articles and technical papers.

43. My supervisor bases salary and promotion recommendaitons on technical performance.

44. The company has a discouraging and indifferent attitude toward technological innovation and excellence.

45. Challanging work is often assigned only to newer engineers.

- 46. Engineers have limited opportunity to use their technical knowledge.

47. Job rotation exposes the engineer to new technical disciplines.

48. My supervisor recognizes and rewards the engineer's efforts to keep technically up-to-date.

49. Job assignments are frequently made to a product or area in which little or no technological change is occurring.

50. Other engineers in the company prefer to keep new ideas to themselves.

51. Low value is placed on th development of engineers.

52. Assignments are made in the area of the engineer's personal interest, when possible.

53. Job assignments are frequently repetitious and formatted.

- 54. Engineers who receive advanced training and degrees receive formal recognition in the company.

55. Engineers are reassigned rather than termianted when projects are cut or end.

56. The company pays for subscriptions to tecinical and trade journals for the engineer.

57. Peers are able to catch logical and analytical errors in designs and ideas.

B. Rewards and Outcomes Related to an Engineer's Job

There are many types of rewards and outcomes that engineers might receive as a result of their work. We are intrested in identifying the rewards/outcomes that are most important to you and in assessing the relationship between thse rewards and yor development.

Listed below are rewards/outcomes that other engineers have identified as being of potential importance to them. Please read the following instructions carefully and complete each column for your important rewards. 
1. In COLUMN A check the 10 rewards and outcomes that are most important to you.

2. In COLUMN B indicate how important each of these 10 rewards is to you using the following rating scale:

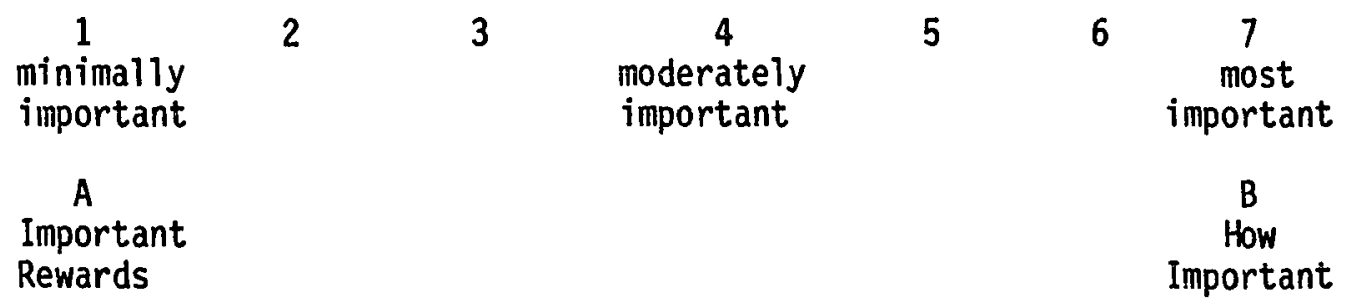

1. Recognition for accomplishments and technical success

2. Advancement based on quality work performance

3. Saiary and merit increases

4. Role as technical consultant to other projects

5. Customer satisfaction

6. Sense of achievment from work assignment

- 7. Support for maintaining and expanding technical skills

8. Challenging work assignment

9. Role as mentor for younger engineers

- 10. Knowing how your assignment fits into the overall project

11. More time for non-work related activities

12. Assignment in forefront of technology

- 13. Company reputation for technological leadership and excellence

14. Job security

15. Encouragement of my creative and innovative ability.

16. Opportunity to exercise personal initiative in assignment

17. Positive relations with supervisor

18. Major responsibility for a project

19. Availability of technical library

20. Support for writing technical articles and books

21. Support for professional memberships, attendance at professional meetings, and technical presentations

22. Good relations with peers

23. Other

3. In COLUMN $C$ rate the likelihood of receiving each of the 10 rewards you checked if your technical skills stayed at their current level during the next 2 years.

4. In COLUMN $D$ rate the likelihood of receiving each of the 10 rewards if you became more technically up-to-date during the next 2 years. 


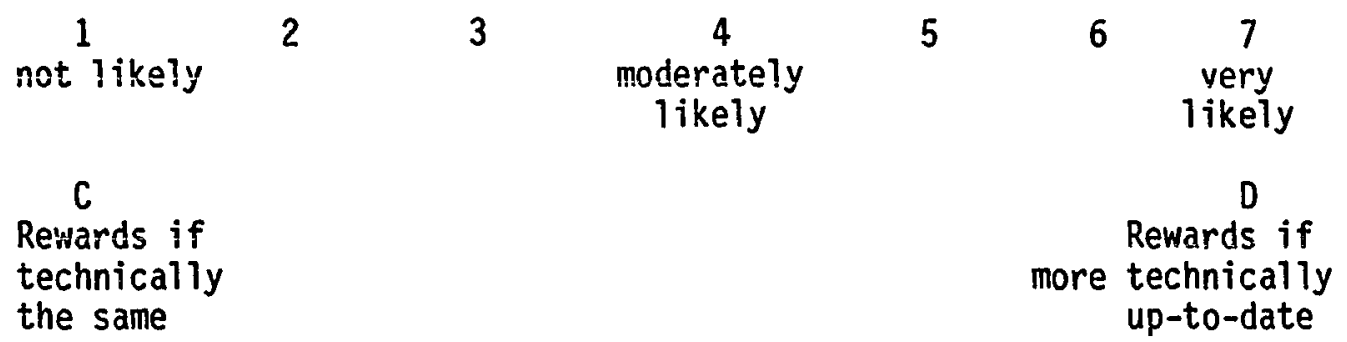

1. Recognition for accomplishments and technical success

2. Advancement based on quality work performance

3. Salary and merit increases

4. Role as technical consultant to other projer.ts

5. Customer satisfaction

6. Sense of achievment from work assignment

- 7. Support for maintaining and expanding technical skills

8. Challenging work assignment

9. Role as mentor for younger engineers

10. Knowing how your assignment fits into the overall project

11. More time for non-work related activities

12. Assignment in forefront of technology

- 13. Company reputation for technologicail leadership and excellence

14. Job security

15. Encouragement of my creative and innovative ability

16. Opportunity to exercise personal initiative in assignment

17. Positive relations with supervisor

- 18. Major responsibility for a project

- 19. Availability of technical library

- 20. Support for writing technical articles and books

- 21. Support for professional memberships, attendance at professional meetings, and technical presentations

22. Good relations with peers

23. Other

C. Value of Various Activities for Keeping Engineers Technically Up-to-Date

There are many possible activities that might increase technical knowledge and skills. Please indicate your judgment of the value of each of the following activities as a way of keeping technically up-to-date. Use the scale below to make your judgments. Place the number indicating your judgment in the space to the left of each activity.

If I take place in "this activity" (see list below) it is that I will become more technically up-to-date. 


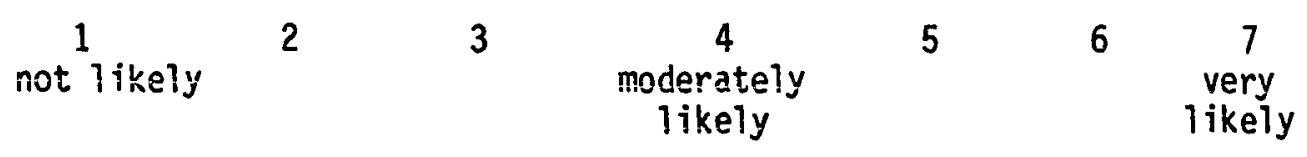

1. Pursue an advanced engineering degree.

2. Get professional certification.

3. Attend local professional society chapter meeting.

4. Attend in-house technical seminars and short courses.

5. Publish a paper in a technical journal.

6. Read technical journals.

7. Take an occasional technical course at a university or college.

8. Attend national professional society meetings.

9. Discuss technical matters with others in my organization.

10. Present a paper at a professional society meeting.

11. Attend non-company technical seminrs and short courses.

12. Read current tehnical textbooks on own schedule.

13. Read trade journals and magazines.

14. Talk with engineers in other organizations.

15. Receive a challenging technical job assignment.

16. Work with interdisiplinary project teams.

17. Teach a technical course at local college or university.

18. Lead seminars and short courses for organization or professional society.

19. Use electronic technical database. 20.

21.

If there are other ways of updating, please specify these and rate them.

Send copy of survey results. YES NO

I am available for a follow-up interview. YES NO

Return to Cheryl Hubbard, Y6-047 by May 20th 
APPENDIX B 
May 9, 1985

Dear Engineer:

Cheryl hubbard, as part of her doctoral studies, is conducting a study investigating the development climate for engineers in the company. Enclosed is a questionnaire designed to assist her completing the study. Your opinions are of utmost importance. I would appreciate your taking 30 minutes of your time to give your candid responses. Ali individual responses will be kept in strictest confidence. Please return the completed survey to Chery1, Y6-047, by May 20.

A copy of the study results will be available to participants. Check the appropriate space on the questionnaire if you would like a copy. Al so indicate whether or not you would be willing to participate in a follow-up interyiew.

We appreciate your cooperation.

Sincerely,

Eddie R. Ward, Director

Corporate Development and Personnel Relations 
APPENDIX C 
May 23, 1985

Dear

Recently you received a questionnaire related to the development climate of engineers. This is just a reminder to ask again for your support by completing and returning the questionnaire.

Your responses are extremely valuable for completion of this study. If you have not yet completed the questionnaire, would you please take a few minutes to do so and return it to me by May 30 .

Sincerely,

Cheryl Hubbard, Manager

$\mathrm{CH} / 1 \mathrm{a}$ 